\title{
GERSON LOPES PALHARES
}

Sistema porta hepático do bagre africano Clarias gariepinus Burchell, 1822 (Clariidae, Siluriformes, Ostariophysii) 


\section{GERSON LOPES PALHARES}

Sistema porta hepático do bagre africano Clarias gariepinus Burchell, 1822

(Clariidae, Siluriformes, Ostariophysii)

Dissertação apresentada ao Programa de Pósgraduação em Anatomia dos Animais Domésticos e Silvestres da Faculdade de Medicina Veterinária e Zootecnia da Universidade de São Paulo para obtenção do título de Mestre em Ciências

\section{Departamento:}

Cirurgia

Área de concentração:

Anatomia dos Animais Domésticos e Silvestres

\section{Orientador:}

Prof. Dr. Francisco Javier Hernandez Blasquez 
Autorizo a reprodução parcial ou total desta obra, para fins acadêmicos, desde que citada a fonte.

DADOS INTERNACIONAIS DE CATALOGAÇÃO-NA-PUBLICAÇÃO

(Biblioteca da Faculdade de Medicina Veterinária e Zootecnia da Universidade de São Paulo)

T. 1429 Palhares, Gerson Lopes

FMVZ Sistema porta hepático do bagre africano Clarias gariepinus Burchell, 1822 (Clariidae, Siluriformes, Ostariophysii) / Gerson Lopes Palhares. São Paulo : G. L. Palhares, 2004.

$101 \mathrm{f}$ : : il.

Dissertação (mestrado) - Universidade de São Paulo. Faculdade de Medicina Veterinária e Zootecnia. Departamento de Cirurgia, 2004.

Programa de Pós-graduação: Anatomia dos Animais Domésticos e Silvestres.

Área de concentração: Anatomia dos Animais Domésticos e Silvestres.

Orientador: Prof. Dr. Francisco Javier Hernandez Blasquez.

1. Anatomia. 2. Sistema porta hepático. 4. Fígado. 5. Bagre africano. I. Título. 


\section{UNIVERSIDADE DE SÃO PAULO Faculdade de Medicina Veterinária e Zootecnia Cidade Universitária "Armando de Salles Oliveira" Comissão Bioética \\ CERTIFICADO}

Certificamos que o Projeto intitulado "Sistema porta hepático do bagre africano Clarias geriepinus Burchell, 1822 (Clariidae, Siluriformes, Ostariophysii)y", protocolo $\mathrm{n}^{\circ} 311 / 2003$, sob a responsabilidade do Prof. Dr. Francisco Javier Hernandez Blasquez, utilizando 20 bagres africanos, está de acordo com os princípios éticos de experimentação animal da Comissão de Bioética da Faculdade de Medicina Veterinária e Zootecnia da Universidade de São Paulo e foi aprovado "ad referendun".

(We certify that the Research "Hepatic portal system of the African catfish Clarias gariepinus Burchell, 1822" protocol number 311/2003, utilizing 20 catfishes, under the responsibility of Prof. Dr. Francisco Javier Hernandez Blasquez, indeterminate number of the swiss, agree with Ethical Principles in Animal Research adopted by Bioethic Commission of the Faculty of Veterinary Medicine and Zootechny of University of São Paulo and was approved "ad referendun").

São Paulo, 07 de outubro de 2004

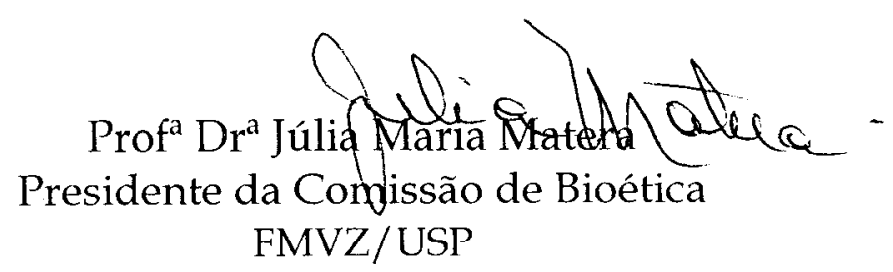

Av. Prof. Dr. Orlando Marques de Paiva, 87 - 05508-000 - Cid. Univ.. "Armando de Salles Oliveira" Fones: (011) 3091-7671/3091-7676 Fax: (011) 3032-2224 


\section{FOLHA DE AVALIAÇÃo}

Nome do autor: PALHARES, Gerson Lopes

Título: Sistema porta hepático do bagre africano Clarias gariepinus Burchell, 1822 (Clariidae, Siluriformes, Ostariophysii)

Dissertação apresentada ao Programa de Pós-graduação em Anatomia dos Animais Domésticos e Silvestres da Faculdade de Medicina Veterinária e Zootecnia da Universidade de São Paulo para obtenção do título de Mestre em Ciências

Data:

Banca Examinadora

Prof. Dr.

Assinatura:

Prof. Dr.

Assinatura:

Prof. Dr.

Assinatura:
Instituição:

Julgamento:

Instituição:

Julgamento:

Instituição:

Julgamento: 
Dedico esta obra à minha esposa Elisa Cristina Strick Palhares e à minha filha Fernanda Strick Palhares pela atenção, paciência e amor que dedicaram a mim durante todo o periodo em que este trabalho foi executado, e em todos os momentos dificeis pelos quais passei durante esse periodo, sendo sempre solícitas e cultivando em mim a calma, a fé e a perseverança. 
Agradeço, especialmente, ao Prof. Dr. Wagner Intelizano, pelo planejamento, implantação, execução e conclusão desta obra, pois sem sua indiscutivel capacidade técnica, acadêmica e cientifica e, acima de tudo, sem sua amizade, lealdade, presteza e caráter, este trabalho não seria concluído. 


\section{AGRADECIMENTOS}

$\checkmark$ Agradeço, acima de tudo, a "Deus", a "Jesus Cristo" e à Mãe Amada "Maria de Nazaré", pois sem essa força espiritual o trabalho não seria concluído;

$\checkmark$ Agradeço aos meus pais, Claudio Palhares e Elizabeth Lopes Palhares, por serem os responsáveis pela minha existência e pelas lições de caráter e honestidade que me passaram ao longo de toda a minha vida;

$\checkmark$ Agradeço ao meu grande tutor, Prof. Dr. Francisco Javier Hernandez Blazquez, pela amizade, presteza e orientação ao longo de toda a trajetória que envolveu este estudo;

$\checkmark$ Agradeço à $\operatorname{Prof}^{\mathrm{a}} \mathrm{Dr}^{\mathrm{a}}$ Maria de Fátima Martins, por toda a confiança depositada em mim e pelo auxílio prestado ao meu ingresso no Programa de Pós-graduação em Anatomia dos Animais Domésticos e Silvestres da Faculdade de Medicina Veterinária e Zootecnia da Universidade de São Paulo;

$\checkmark$ Agradeço ao Prof. e amigo Edson Roberto de Oliveira pelo apoio nas traduções e nas correções ortográficas de diversas partes do trabalho e por ser uma pessoa leal e maravilhosa, sempre disponível a ajudar um amigo;

$\checkmark$ Agradeço à Prof ${ }^{a}$ e amiga Alessandra Pisani da Silva por sua ajuda na conclusão da parte gráfica e visual deste trabalho e por ser uma pessoa tão bondosa e prestativa;

$\checkmark$ Agradeço ao Prof. Paulo Meinberg e às Faculdades Cantareira por proporcionarem as instalações necessárias ao alojamento e às dissecações dos peixes utilizados neste projeto;

$\checkmark$ Agradeço ao Prof. Dr. José Roberto Machado Cunha da Silva por ceder as instalações do biotério do Instituto de Ciências Biomédicas da USP, e por toda a orientação em vários pontos controversos do trabalho; 
$\checkmark$ Agradeço ao Prof. Dr. Franklin A. Sterman por oferecer, de bom grado, as instalações e os serviços do Setor de Radiologia do Hospital Veterinário da USP, indispensáveis à execução das radiografias utilizadas neste estudo;

$\checkmark$ Agradeço ao Prof. e Mestre Nilton Pedro dos Santos pelas orientações e por auxiliar na busca dos espécimes de bagres utilizados neste trabalho junto ao CEPTA, em Pirassununga, São Paulo;

$\checkmark$ Agradeço aos professores do Departamento de Cirurgia e aos colegas pós-graduandos pelo apoio que me deram durante a execução deste trabalho. 


\section{RESUMO}

PALHARES, G. L. Sistema porta hepático do bagre africano Clarias gariepinus Burchell, 1822 (Clariidae, Siluriformes, Ostariophysii). [Hepatic portal system of the African catfish Clarias gariepinus Burchell, 1822 (Clariidae, Siluriformes, Ostariophysii)]. 2004. 101 f. Dissertação (Mestrado em Ciências) - Faculdade de Medicina Veterinária e Zootecnia, Universidade de São Paulo, São Paulo, 2004.

Estudou-se o sistema porta hepático do bagre africano Clarias gariepinus Burchell, 1822, sob o ponto de vista da anatomia macroscópica e microscópica, utilizando-se várias técnicas anatômicas, que envolveram anestesia, injeção de substâncias recomendadas ao estudo do sistema vascular (látex, nanquim, cloreto de polivinil e substância radiopaca), dissecação, corrosão ou radiografia, conforme a exigência de cada técnica, como meio de compreensão da anatomia vascular do fígado deste peixe. Foram utilizados 16 exemplares do sexo feminino, com comprimento total entre 45 e 53,5 centímetros e massa corpórea entre 575 e 1068 gramas. Para a execução dessas técnicas, os peixes foram devidamente anestesiados com benzocaína, garantindo a narcose profunda e evitando qualquer tipo de sofrimento a eles. Os resultados obtidos com essas técnicas mostram que o fígado de Clarias gariepinus ocupa a cavidade abdominal cranial e apresenta uma lobação bem definida, sendo constituído por dois grandes lobos, denominados direito e esquerdo, conectados cranialmente por uma ponte dorsal à transição entre o esôfago e o estômago. O lobo esquerdo apresenta-se ligeiramente maior que o contralateral. Em suas extremidades caudais, os lobos esquerdo e direito formam um ápice pontiagudo, de formato triangular, que continua tenuemente através de um istmo eminentemente vascular que liga esses ápices a dois outros lobos, chamados acessórios direito e esquerdo, bem menores que os demais, e que ficam seqüestrados em um recesso peritoneal, lateral à cavidade abdominal. Os resultados indicam ainda que o sistema porta hepático de Clarias gariepinus está representado por duas 
veias portas principais denominadas direita e esquerda, levemente assimétricas em diâmetro, que drenam o sangue das vísceras abdominais (baço, estômago, vesícula biliar, intestino e gônadas) através dos tributários viscerais desse sistema. Ainda, devido a uma situação peculiar dos lobos acessórios, definem-se mais duas veias portas secundárias ligadas às principais e designadas igualmente por acessórias, uma esquerda e outra direita. Ambas as vv. portas principais se ramificam, atingindo o hilo da face visceral, enquanto que as vv. acessórias penetram por uma região restrita do lobo. Através de ramos interlobares, ambas as vv. portas principais se anastomosam no parênquima hepático. A v. porta esquerda, com discreto aumento de diâmetro, forma-se pela terminação da v. intestinal, concomitante à desembocadura da v. gastrointestinal e da v. porta acessória esquerda. A v. porta direita se define pela terminação da v. intestinal cranial, simultaneamente à chegada da v. porta acessória ipsilateral, drenando sangue do intestino médio, estômago e vesícula biliar. Nessa espécie, também estão caracterizados dois sítios de comunicação entre o sistema porta hepático e o sistema porta renal através de anastomoses em cada v. porta. Sob as condições em que o trabalho foi desenvolvido e considerando-se a metodologia proposta e a análise dos resultados, conclui-se que todos os métodos foram adequados ao estudo do aparelho circulatório de Clarias gariepinus, sendo recomendados para experimentos futuros sobre o mesmo assunto em outras espécies piscícolas; porém, dentre as três metodologias utilizadas para análises macroscópicas, a injeção de cloreto de polivinil seguida de corrosão das peças e subseqüente obtenção de moldes vasculares mostrou-se mais eficiente na marcação e identificação dos vasos que compõem o sistema porta hepático deste peixe. Concluise também que, devido à presença dos lobos acessórios, a lobação hepática é peculiar nesta espécie, em virtude da posição ocupada por estes lobos, assim como a circulação porta, em função das duas veias porta acessórias, e ainda a anastomose entre as duas veias porta principais, 
característica que deve ser considerada em trabalhos que envolvam cirurgia hepática no bagre africano.

Palavras-chave: Anatomia. Sistema porta hepático. Fígado. Bagre africano. 


\begin{abstract}
PALHARES, G. L. Hepatic portal system of the African catfish Clarias gariepinus Burchell, 1822 (Clariidae, Siluriformes, Ostariophysii). [Sistema porta hepático do bagre africano Clarias gariepinus Burchell, 1822 (Clariidae, Siluriformes, Ostariophysii)]. 2004. 101 f. Dissertação (Mestrado em Ciências) - Faculdade de Medicina Veterinária e Zootecnia, Universidade de São Paulo, São Paulo, 2004.
\end{abstract}

The hepatic portal system of the African catfish Clarias gariepinus Burchell, 1822, was studied considering the macroscopic and microscopic anatomy, by means of several anatomic techniques, including anesthesia, injection of substances recommended to the study of the vascular system (latex, Indian ink, polyvinyl chloride and radiopaque substance), dissection, corrosion or radiography, according to the requirement of each technique, as a way of understanding the hepatic circulatory pathway in the African catfish. Sixteen female specimen were used, being the entire length between 45 and 53.5 centimeters and the corporal mass between 575 and 1068 grams. To perform these techniques, the fishes were adequately anesthetized with benzocaine, assuring the deep narcosis and preventing them from any suffering. The results obtained through such techniques show that the liver of Clarias gariepinus occupies the cranial abdominal cavity and shows a clear lobation, the liver consisting of two large lobes, called right and left, cranially connected by a bridge dorsal to the transition between the esophagus and the stomach. The left lobe is slightly larger than the contralateral lobe. At their caudal ends, the left and the right lobes form a sharp triangle-like apex that tenuously passes through a strip eminently vascular that links these apexes with two other lobes, called right and left accessories, much smaller than the others, these lobes being wrapped in a peritoneal recess, situated at the side of the abdominal cavity. The results still show that the hepatic portal system of Clarias gariepinus is represented by two main portal veins named right and left, slightly asymmetric in diameter, that empty the blood out of the 
abdominal viscera (spleen, stomach, gall bladder, intestine and gonads) through the visceral tributaries of this system. Furthermore, due to a peculiar situation of the accessory lobes, two other secondary portal veins were defined; they are connected to the main veins and are equally called right and left accessories. Both the main portal veins branch, reaching the hilum of the visceral face, whereas the accessory veins go into a restricted region of the lobe. Through interlobar branches, both the main portal veins anastomose in the hepatic parenchyma. The left portal vein, with a slight increase in diameter, is formed by the terminatio of the intestinal vein, accompanying the discharge of the gastrointestinal vein and the accessory left portal vein. The right portal vein is defined by the terminatio of the cranial intestinal vein, simultaneously with the accessory ipsilateral portal vein, emptying the blood out of the medial intestine, stomach and gall bladder. In this species it is also possible to distinguish two connecting sites between the hepatic portal system and the renal portal system by means of anastomoses in each portal vein. Under the conditions in which the experiment was carried out and considering the methodology suggested and the analysis of the results, it is concluded that all the methods were suitable for the study of the circulatory system of Clarias gariepinus, being recommended for future tests on the same subject in other fish species; however, among the three methodologies used in the macroscopic analyses, the injection of polyvinyl chloride followed by the corrosion of pieces and subsequent getting of vascular moulds was believed to be more efficient at the marking and identification of the vessels that compose the hepatic portal system of this fish. It was also concluded that, due to the presence of the accessory lobes, the hepatic lobation is peculiar in this species because of the position occupied by these lobes, as well as the portal circulation, caused by the two accessory portal veins, in addition to the anastomose between the two main portal veins, a characteristic that must be thought of in studies of hepatic surgery in the African catfish. 
Key words: Anatomy. Hepatic portal system. Liver. African catfish. 


\section{SUMÁRIO}

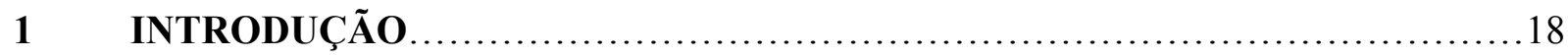

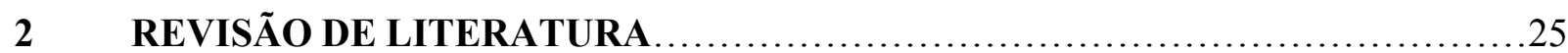

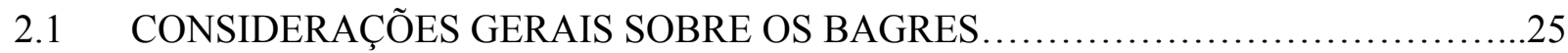

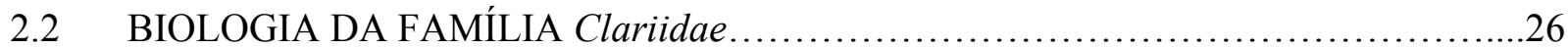

2.3 BIOLOGIA, HÁBITAT E REPRODUÇÃO DE Clarias gariepinus.........................27

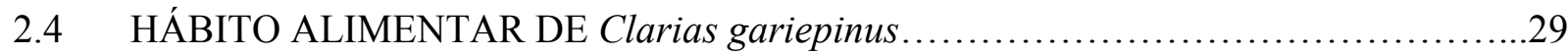

2.5 ETIMOLOGIA DE Clarias gariepinus (Burchell, 1822) ................................29

2.6 FÍGADO (FUNÇÕES E ASPECTOS MACROSCÓPICOS)..............................29

2.7 FÍGADO (ASPECTOS MICROSCÓPICOS) .........................................

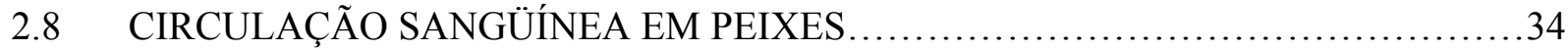

2.9 SISTEMA PORTA HEPÁTICO EM PEIXES EM GERAL E EM Clarias gariepinus...36

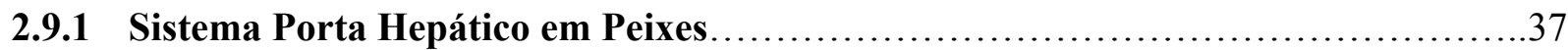

2.9.2 Sistema Porta Hepático em Clarias gariepinus.........................................42

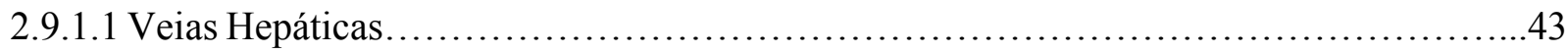

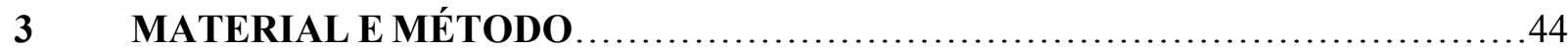

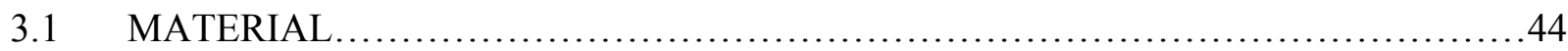

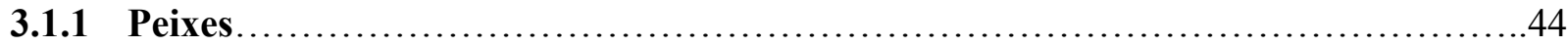

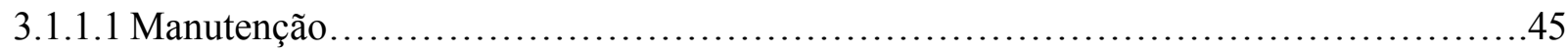

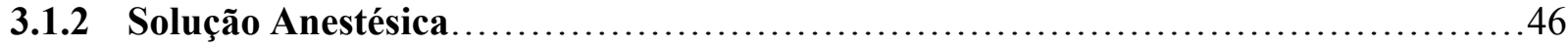

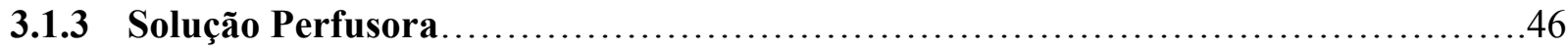

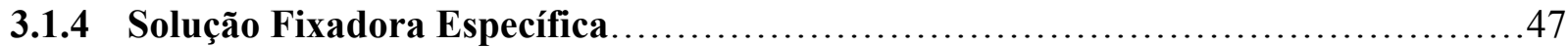

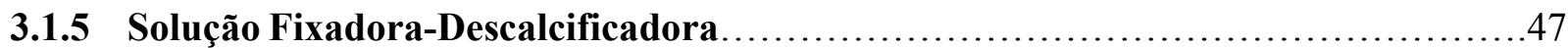




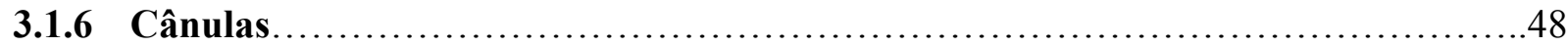

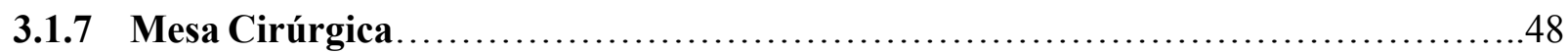

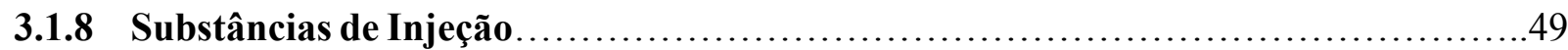

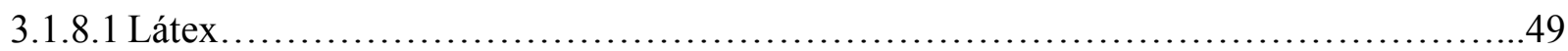

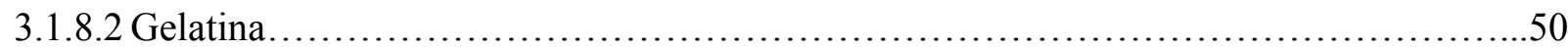

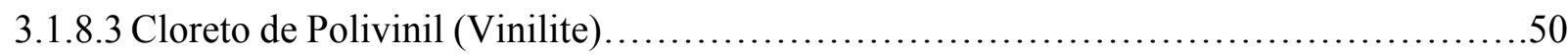

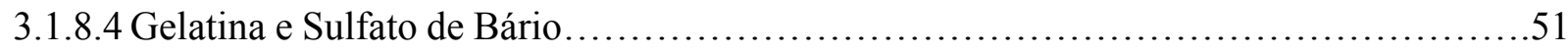

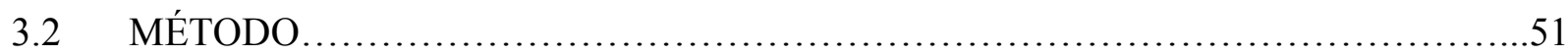

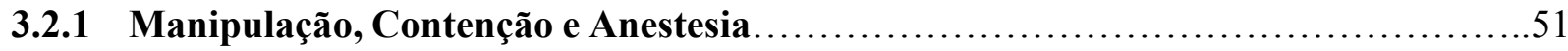

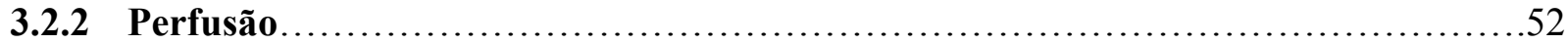

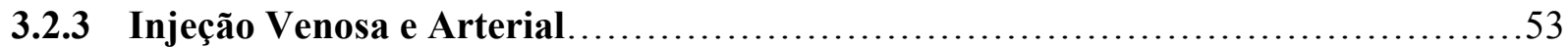

3.2.4 Preparo das Peças para Dissecação........................................... 55

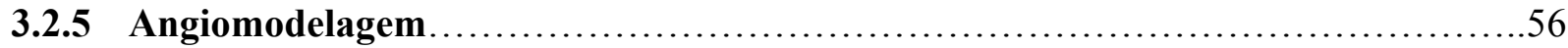

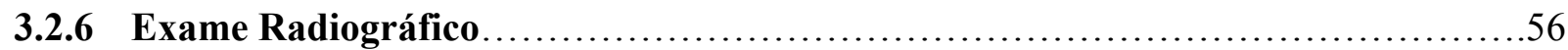

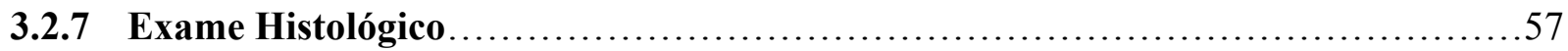

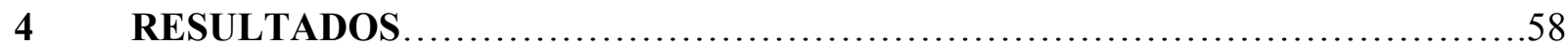

4.1 CONFIGURAÇÃO EXTERNA DO FÍGADO ......................................58

4.2 CIRCULAÇÃO PORTA............................................................63

4.3 V. PORTA ESQUERDA.................................................... 65

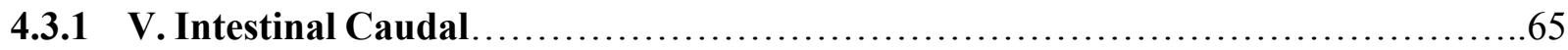

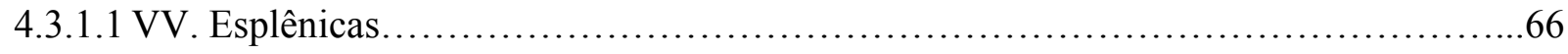

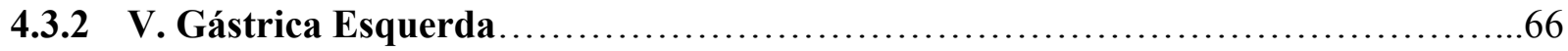

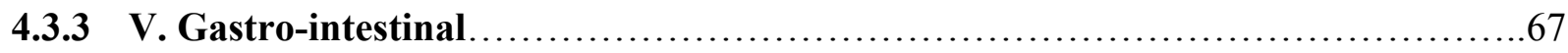

4.3.3.1 V. Gástrica Direita................................................................ 


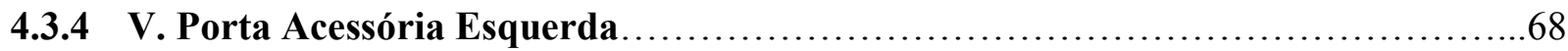

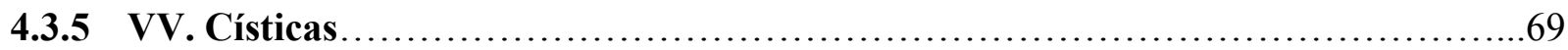

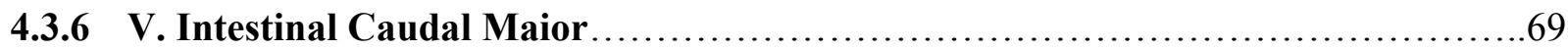

4.3.6.1 Ramo Anastomótico com a V. Caudal..........................................70

4.3.6.2 VV. Gonadais..................................................................... 70

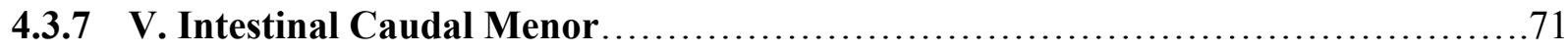

4.4 V. PORTA DIREITA ......................................................... 71

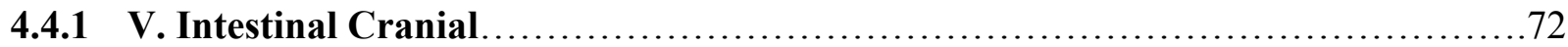

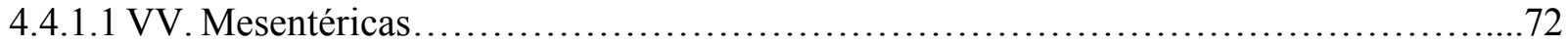

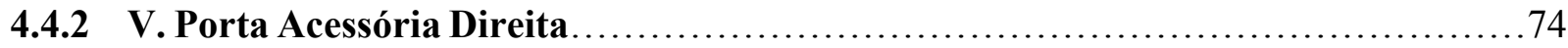

4.4.2.1 Ramo Anastomótico com a Veia Porta Renal Direita....................................74

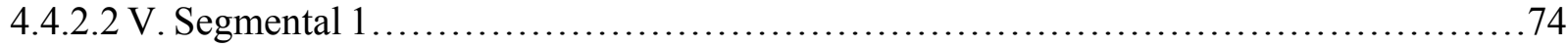

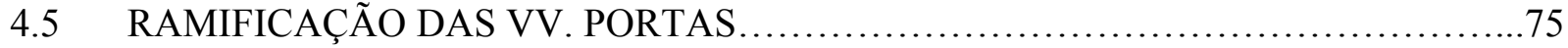

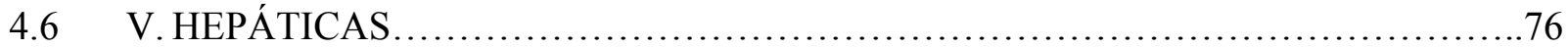

4.7 HISTOLOGIA DO FÍGADO DE Clarias gariepinus.............................. 77

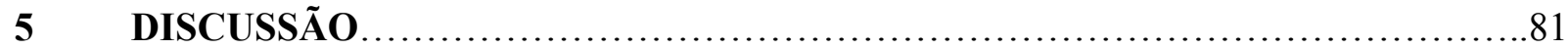

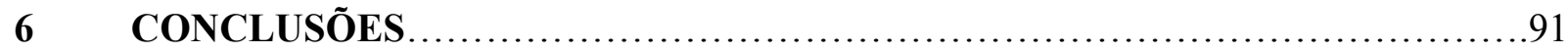

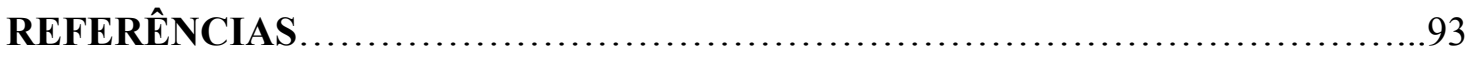

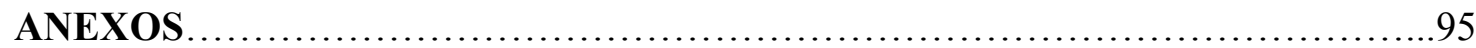




\section{INTRODUÇÃO}

Há mais peixes no mundo do que animais de qualquer outro grupo de vertebrados, tanto em termos individuais, como em número de espécies. Cohen (1970), em sua revisão sobre espécies recentes, fornece as seguintes cifras referentes às principais classes: 50 espécies de Agnatha, de 515 a 555 de Chondrichthyes e de 19.135 a 20.980 de Osteichthyes. O número total de espécies supera aquele encontrado em todos os grupos de vertebrados juntos, o que não é de se espantar, considerando-se que, aproximadamente, 4/5 da superfície terrestre é coberta por água.

A classe Osteichthyes compreende tanto os peixes ósseos, como as diversas espécies familiares de peixes de água doce e de ambiente marinho (UZUNIAN; CALDINI JR., 2002). Hildebrand (1995) comenta que os peixes ósseos evoluíram de ancestrais obscuros há pouco mais de 400 milhões de anos. Por volta de 150 milhões de anos depois estes peixes eram superados em número, primeiro pelos placodermes, depois pelos condríctes, mas, desde o início do Permiano, os peixes ósseos têm dominado as águas do planeta. Segundo o mesmo autor, desde o fim da era Mesozóica estes peixes têm sido os mais abundantes de todos os vertebrados. Seus hábitats e estruturas parecem ser tão diversos quanto permite a adaptação comum à vida aquática.

Hildebrand (1995) relata que a maioria dos peixes da classe Osteichthyes tem crânio, vértebras, cinturas, raios das nadadeiras e escamas ósseos. Alguns têm cartilagem, que substitui secundariamente o osso presente nos ancestrais, já que estes peixes retêm mais osso no esqueleto interno do que os outros peixes das outras classes. O autor refere-se ainda aos peixes ósseos como sendo os únicos vertebrados que possuem as brânquias, de cada lado do corpo, no interior de uma câmara comum recoberta por um opérculo ósseo móvel. Estes peixes têm vários tipos de nadadeiras, escamas e vértebras e, sem dúvida, diferem das dos 
outros peixes das outras classes. A cintura escapular ou peitoral está conectada ao crânio por uma série de ossos. Geralmente apresentam pulmão ou bexiga natatória.

Grande parte dos peixes ósseos pertence à subclasse Actinopterygii, ou peixes de nadadeiras raiadas. As membranas das nadadeiras pares são suportadas pelos raios ósseos que irradiam da base da nadadeira. Conseqüentemente, as nadadeiras não têm hastes carnosas, como as dos peixes da próxima subclasse (Sarcopterygii). O padrão dos ossos cranianos e a anatomia do sistema venoso e ductos reprodutivos também são distintos e mostram, claramente, que estes peixes não incluem os ancestrais dos vertebrados terrestres. Os actinopiterígios são classificados em três grupos denominados Chondrostei, Holostei e Teleostei, os quais são considerados como formando uma seqüência evolutiva pela ordem dos nomes (HILDEBRAND, 1995).

A maioria dos peixes atuais são Teleostei; apresentam muitas variações na estrutura caudal e craniana e são agrupados em quatro clados de tamanho e diversidade variáveis, os Osteoglossomorpha, os Elopomorpha, os Clupeomorpha e os Euteleostei, que constitui o maior grupo dentre os Teleostei. O estoque basal dos Euteleostei é representado atualmente pelos Ostariophysi (super-ordem à qual se enquadra a ordem Siluriformes) e pelos Salmoniformes (POUGH, 1999).

O maior número de espécies de peixes é observado no mar, mas há muitas outras que são encontradas na água doce. Entre estas, os maiores são os peixes-espátula (Polyodon spathula; ordem Acipenseriformes), certos bagres (ordem Siluriformes) e os esturjões (Acipenser sp; ordem Acipenseriformes); alguns bagres da Europa e da Ásia chegam a medir cerca de três metros. Calcula-se que $58,2 \%$ das espécies viventes de peixes são marinhas e 41,2\% são de água doce.

Os bagres enquadram-se em uma ordem com grande número de representantes denominada Siluriformes, que está dividida em, aproximadamente, 31 famílias catalogadas. 
Dentre as famílias que compõem a ordem Siliriformes uma das que mais se destaca, pela importância comercial e pelo número de representantes, é a família Clariidae, caracterizada pela capacidade de locomoção fora d'água e pela presença de um aparato de respiração auxiliar denominado órgão suprabranquial (Anexos A e B), o que possibilita que os peixes utilizem ar atmosférico durante o trajeto percorrido fora d'água, permitindo ainda que os animais sobrevivam em água pobremente oxigenada por um longo período. Os Clarídeos são peixes muito vigorosos e que sobrevivem bem em cativeiro; são extremamente vorazes, sendo que várias espécies são consideradas predadores agressivos, que tentam escapar dos tanques no período noturno em busca de comida (BURGESS, 1989).

O gênero Clarias é o mais numeroso dentro da família Clariidae, contando com 45 espécies que se distribuem, naturalmente, da África às Filipinas. Uma boa parte das espécies que compõem esse gênero é considerada de ocorrência comum, e comercialmente importante, sendo utilizada como alimento em diversas áreas (BURGESS, 1989).

Devido principalmente à importância comercial que algumas espécies de bagres do gênero Clarias passaram a representar dentro do mercado de produtos piscícolas, especialmente naqueles países em que a pesca predatória e a criação comercial de peixes assumem um papel relevante em suas balanças comerciais, iniciou-se, no começo do século vinte, na África, e por iniciativa dos vários colonizadores do continente, a criação em cativeiro de algumas espécies do referido gênero. Por cerca de meio século, o interesse pela produção comercial dividiu-se com a exploração de tilápia que apresentava melhores resultados (TEUGELS, 1986). Mais recentemente, com a definição taxonômica das espécies de interesse zootécnico, surgiram alguns movimentos para a criação racional de bagres em algumas partes do mundo, destacando-se, na Holanda, o Centro Gerador de Tecnologia de Cultivo da Espécie Clarias gariepinus, criado pelo Departamento de Piscicultura e Pesca da Universidade de Wageningen (CLARIAS, 1994). 
No Brasil, a inexistência de técnicas para a propagação artificial de peixes nativos fez com que, entre o final do século 19 e boa parte do século 20, fossem importadas espécies de outros países, com técnicas de criação já bem conhecidas: os órgãos oficiais de incentivo à aqüicultura trouxeram de início a carpa (Cyprinus carpio) e a truta-arco-íris (Oncorhynchus mykiss), e mais recentemente (na década de 80), foi introduzido no país o bagre africano Clarias gariepinus (VIEIRA, 2001).

A partir de sua introdução e disseminação no Brasil, iniciou-se uma exaustiva trajetória de fatos conflitantes que fizeram com que surgissem duas frentes com pontos de vista bastante distintos: de um lado, alguns ambientalistas que o descrevem como um grande inimigo da biodiversidade nativa, capaz de trazer sérios problemas à ictiofauna brasileira; do outro, os aqüicultores, que o vêm como um peixe excelente para se cultivar (VIEIRA, 2001). O fato é que o bagre africano já está perfeitamente adaptado às condições climáticas brasileiras, e toda a discussão deveria ter sido feita antes de 1986, ano em que foi introduzido no país (CLARIAS, 1994). Provavelmente, a principal razão para trazer Clarias gariepinus para o país foi pela tentativa de utilizá-lo em peixamentos (as chamadas introduções artificiais), na expectativa de que ele se estabelecesse em um novo ambiente natural; isso de fato aconteceu, porém, sob o ponto de vista da manutenção da integridade dos ambientes aquáticos brasileiros, talvez não tenha sido uma atitude acertada, devido a uma série de problemas de ordem ambiental que eles passaram a ocasionar em alguns ecossistemas aquáticos brasileiros (VIEIRA, 2001).

Vieira (2001) comenta que, embora os peixamentos possam aumentar a disponibilidade de peixes, fato raramente demonstrado no Brasil, eles não têm sucesso na manutenção da biodiversidade ou na recuperação das funções ecológicas, pois não são direcionados para isso. É interessante notar ainda que, embora tenham em geral o objetivo de recuperar populações e/ou incrementar a pesca, os peixamentos estão vinculados diretamente 
a duas importantes causas da redução de populações de peixes: introdução de espécies exóticas e hibridização com outras espécies ou subespécies.

Para corroborar as palavras de Vieira (2001), é interessante relatar os fatos atribuídos à inclusão do bagre africano (Clarias gariepinus) em nossa fauna aqüícola. A introdução dessa espécie exótica no Brasil a partir de 1986, sem ter sido feito um estudo para prever as conseqüências que isso poderia causar, teve um desfecho negativo a ponto de se observar, em pouco tempo, a invasão de bacias hidrográficas até então não habitadas por esse peixe, devido à sua capacidade de caminhar e respirar fora d'água. Além disso, seu poder de proliferação e a facilidade de adaptação em condições adversas facilitaram sua disseminação, tornando-o uma ameaça às espécies nativas. A partir dessa observação, o Instituto Brasileiro do Meio Ambiente e dos Recursos Naturais Renováveis (1994) (órgão responsável pelo monitoramento da fauna e da flora no Brasil), tomou uma atitude importante lançando a Portaria $n^{\circ}$ 142/94, de 22 de dezembro de 1994, determinando, em seu artigo $1^{\circ}$, a proibição da introdução, transferência, cultivo e comercialização de formas vivas de Clarias gariepinus nas áreas abrangidas pela bacia dos rios Amazonas e Paraguai (compreendendo seus afluentes, lagos e lagoas marginais).

Diante de todas essas considerações é fácil perceber como se torna relevante um estudo mais acurado dos aspectos relacionados à biologia, ao comportamento, à adaptação e ao cultivo do bagre africano (Clarias gariepinus), uma vez que, sua introdução no Brasil acarretou sérios problemas, embora tenha apresentado características zootécnicas muito interessantes em nossas condições ambientais.

Além disso, conhecer as características morfofisiológicas e comportamentais de Clarias gariepinus reveste-se de grande importância para que se possa utilizá-lo como objeto de estudo em situações mais específicas e objetivas, levando em consideração sua brilhante capacidade de sobrevivência fora d'água por longos períodos, característica essa atribuída à 
existência do órgão suprabranquial, e também pelo seu surpreendente poder regenerativo de diversos tecidos, em especial, o tecido hepático, como demonstrado por Santos (2003), podendo ser utilizado como excelente modelo biológico nos estudos de regeneração hepática. E para que se conheça um ser vivo a fundo, é fundamental partir de um estudo anátomofuncional desse organismo, contemplando as variações anatômicas e fisiológicas que são constantemente observadas em exemplares de uma mesma espécie, quanto mais as encontradas entre diferentes espécies de um mesmo gênero. Dentre as variações mais comuns estão àquelas relacionadas às particularidades do sistema circulatório, apesar de os peixes apresentarem, muitas vezes, características muito primitivas e bastante simplificadas quanto a sua estrutura vascular.

A partir das considerações feitas acerca da alta capacidade de regeneração de tecidos lesados, e ainda devido à rusticidade e facilidade de adaptação em cativeiro, elegeu-se o bagre africano Clarias gariepinus como espécie suporte para os procedimentos experimentais preconizados nesta pesquisa.

A proposta do estudo baseou-se principalmente na observação e no registro das particularidades do sistema vascular do fígado do bagre africano (Clarias gariepinus), sob o ponto de vista da anatomia macroscópica e microscópica, utilizando-se várias técnicas anatômicas que envolveram anestesia, injeção de substâncias recomendadas ao estudo do sistema vascular (látex, nanquim, cloreto de polivinil e substância radiopaca), dissecação, corrosão ou radiografia, conforme a exigência de cada técnica, e ainda, a composição histológica do fígado desse animal, como meio de compreensão das diferentes funções que esse órgão pode desempenhar para o peixe.

Através da metodologia proposta, o trabalho revela, detalhadamente, a distribuição vascular do sistema porta hepático do bagre africano (Clarias gariepinus) levando-se em consideração seu sistema de irrigação e drenagem sangüínea; além disso, define o número de 
veias porta, quantifica os tributários viscerais que formam o sistema porta, evidencia a união entre o sistema porta hepático e o sistema porta renal e rediscute a nomenclatura vascular desse sistema, disponível na literatura científica. 


\section{REVISÃO DE LITERATURA}

Para melhor sistematização dos assuntos pesquisados, utilizou-se a conduta da descrição fracionada dos aspectos gerais, biológicos, anatômicos etc., com respeito ao bagre africano Clarias gariepinus.

\subsection{CONSIDERAÇÕES GERAIS SOBRE OS BAGRES}

Os bagres fazem parte de uma ordem com grande número de representantes denominada Siluriformes, que foi redefinida por Fink e Fink (1981). De acordo com as informações citadas por Burgess (1989), essa ordem está dividida em, aproximadamente, 31 famílias.

Estima-se que existam, aproximadamente, 2211 espécies em apenas 400 gêneros de bagres catalogados para a ordem inteira, dos quais somente 1300 habitam as águas do Novo Mundo. Os remanescentes estão disseminados nos outros continentes do Mundo, com a concentração mais abundante nas regiões tropicais da África e da Ásia. A distribuição dos bagres parece ser parcialmente limitada pela temperatura, em algumas áreas das porções do extremo sul da América do Sul ou do norte da América do Norte e Eurásia. Os bagres mais primitivos perduram como sobreviventes na América do Sul (NELSON, 1994).

A grande maioria dos bagres habita as águas doces, mas duas famílias, a Plotosidae e a Ariidae, têm considerável representação em todos os ambientes marinhos, tanto quanto, algumas espécies em águas salobras e costais (BURGESS, 1989). 


\subsection{BIOLOGIA DA FAMÍLIA Clariidae}

Burgess (1989), comenta que a capacidade de locomoção fora d'água e o aparato de respiração auxiliar são importantes para a sobrevivência dos Clarídeos. Teugels (1986), considera o aparato de respiração auxiliar como sendo um órgão suprabranquial; esse órgão permite aos peixes utilizar ar atmosférico, e assim, sobreviver em água probremente oxigenada, e até fora d'água, por um longo período. Além disso, são capazes de abandonar a água e caminhar sobre a terra (como mencionado acima) por centenas de metros, usando suas espinhas peitorais e fazendo movimentos sinuosos com seus corpos.

De acordo com Burgess (1989), a transição da água para a terra seca ocorre à noite em busca de alimento, e os peixes podem permanecer fora da água por longos períodos de tempo, desde que, permaneçam suficientemente úmidos. Para auxiliá-los a esse respeito, a pele é relativamente fina e provida com numerosos poros mucosos, para mantê-los lubrificados. Na época de seca, algumas espécies são capazes de enterrarem-se no fundo lamacento, permanecendo ali até que as chuvas retornem. Variações na estrutura do aparato de respiração acessória são muito úteis aos cientistas na identificação de alguns dos Clarideos mais similares.

Os Clarídeos são peixes muito vigorosos e que sobrevivem bem em cativeiro. São, até certo ponto, sensíveis às alterações na qualidade da água, porém são considerados animais de vida longa. São tidos como peixes extremamente vorazes, sendo que, várias espécies qualificam-se como predadores agressivos que vagam ao redor do tanque no período noturno, procurando por comida. Eles prosperam sobre todos os tipos de alimentos vivos e petiscos carnudos, confirmando a característica de voracidade (BURGESS, 1989).

O gênero Clarias é, de longe, o maior gênero da família, contando com 45 espécies, distribuídas da África às Filipinas. Uma boa parte das espécies que compõem esse gênero é 
considerada bastante comum e comercialmente importante, sendo utilizada como alimento em diversas áreas (BURGESS, 1989).

O corpo dos Clarídeos, em geral, é alongado e em formato de torpedo (subcilíndrico) na região das nadadeiras ventrais e então, achatado posteriormente. A cabeça é achatada (Anexo C) e coberta com placas ósseas que são superficialmente rugosas. Em seu hábitat natural, os Clarias reproduzem-se nos primeiros meses da época chuvosa do verão. Os reprodutores preferem as áreas gramadas e inundadas, onde, após uma chuva pesada, observase o macho e a fêmea pareados para desovar, sendo vistos contorcendo-se sobre a grama em água pouco profunda, apenas o bastante para cobri-los. Durante esse período, ambos ficam extremamente expostos e muito vulneráveis aos predadores. A postura dos ovos e a fase larval ocorrem em um período de tempo muito curto (BURGESS, 1989).

\subsection{BIOLOGIA, HÁBITAT E REPRODUÇÃO DE Clarias gariepinus}

Burgess (1989) comenta que, Clarias gariepinus habita uma variedade muito grande de águas na África, onde pode alcançar um comprimento superior a $140 \mathrm{~cm}$, e um peso de 60 kg (atualmente com os indivíduos vivendo sob pressão de pesca, os de, aproximadamente, 70 cm são os mais comuns). Apesar de que a maioria deles é encontrada em água doce, alguns indivíduos também podem ser vistos em águas salobras de alcance superior aos estuários (BURGESS, 1989). Embora Clarias gariepinus seja encontrado, algumas vezes, em águas abertas, é mais comum em áreas marginais rasas. Gosta de águas relativamente fechadas, podendo sobreviver em situação de baixa disponibilidade de oxigênio. $\mathrm{O}$ autor comenta ainda que sua sobrevivência é possível em lama úmida, devido à presença do órgão suprabranquial, não tendo, todavia, capacidade de viver por longos períodos em lama seca, como alguns peixes pulmonados. Teugels (1986), por sua vez, afirma que a espécie Clarias gariepinus é 
encontrada principalmente em águas calmas, em lagoas e em pequenos lagos, podendo também ocorrer em rios profundos e calmos e em rios rápidos. Sua vasta distribuição indica sua habilidade para sobreviver em várias condições ambientais; isso é atribuível, entre outras, à presença do órgão suprabranquial, como já foi dito anteriormente.

Os indivíduos da espécie Clarias gariepinus consomem uma grande variedade de alimentos, mas gostam, particularmente, de pequenos peixes quando adultos. Em ambiente natural, desovam em correntes temporárias pequenas que são originadas durante a estação chuvosa, quando ocorrem as inundações. Um grande número de espécimes migra rio acima ou para as margens de lagos para desovar, usualmente no verão precoce, uma vez que, as primeiras chuvas pesadas da estação chuvosa já começaram. A desova, normalmente, acontece à noite em água rasa. A incubação ocorre em 23 a 30 horas, sob temperatura entre $22^{\circ}$ e $28^{\circ} \mathrm{C}$. Após a incubação, os jovens bagres permanecem nas águas rasas escondidos sob as plantas, onde vivem por cerca de seis meses, migrando em seguida rio abaixo (BURGESS, 1989). Assim como os de Burgess (1989), os relatos de Teugles (1986) indicam que a reprodução acontece durante a estação chuvosa. O autor cita que os peixes migram para os planos inundados para reproduzirem-se; em seguida, retornam ao rio ou lago, enquanto que os jovens permanecem na área inundada. A partir desse momento, os pais não se responsabilizam mais pela prole.

Clarias (1994) comenta que os reprodutores de cativeiro costumam ter entre 1 e $3 \mathrm{~kg}$ de peso vivo, pois animais maiores podem dificultar o manejo. Nas fêmeas, são utilizadas as mesmas técnicas de injeção de hormônios utilizadas para outros peixes e, uma fêmea de $1 \mathrm{~kg}$, pode fornecer cerca de 80.000 ovos. O texto cita ainda que é preciso sacrificar o macho e dissecar os testículos para obtenção do sêmen, que é colocado sobre os óvulos, para que sejam fecundados na presença de água. Os ovos ficam aderentes em poucos segundos após a fecundação. 


\subsection{HÁBITO ALIMENTAR DE Clarias gariepinus}

Clarias gariepinus é uma espécie noturna que se alimenta no crepúsculo, aprisionando uma grande variedade de objetos. Os relatos indicam que eles comem, praticamente, qualquer coisa que se mova, não somente as presas usuais como caracóis, insetos, crustáceos, peixes e mesmo os plânctons, mas também itens não usuais como frutas, plantas, pássaros jovens e carne podre (BURGESS, 1989).

Todos os trabalhos que lidam com análise de alimento de Clarias gariepinus indicam sua característica onívora. Alguns consideram ainda a espécie como um animal necrófago onívoro, comendo tudo o que encontra. Na maioria dos trabalhos, Clarias gariepinus é descrita como um comedor de fundo, que, ocasionalmente, alimenta-se na superfície (TEUGELS, 1986).

2.5 ETIMOLOGIA DE Clarias gariepinus (Burchell, 1822)

Clarias gariepinus: nomeado a partir de sua localidade de origem, o rio Gariep, o nome Hottentot para o rio Laranja, África do Sul (TEUGELS, 1986).

\subsection{FÍGADO (FUNÇÕES E ASPECTOS MACROSCÓPICOS)}

Storer et al. (1998) comentam que todos os vertebrados têm duas grandes glândulas digestivas: o fígado e o pâncreas, ligados por ductos à parte inicial do intestino delgado. $\mathrm{O}$ fígado, a maior "glândula" do corpo, realiza, além da secreção da bílis, diversas outras funções relacionadas com o aparelho digestório e com outras partes do corpo. Em resumo: armazena glicose (em forma de glicogênio) e a fornece ao corpo de modo controlado, 
conforme as necessidades; trabalha na síntese de proteínas, regulando a concentração de aminoácidos no sangue; auxilia na eliminação de venenos, funcionando na decomposição e liberação de produtos de excreção nitrogenada, transformando amônia (produto tóxico do metabolismo de proteínas) em uréia; produz uma substância (fator antianêmico) que auxilia na produção de hemácias - mas ele também destrói hemácias velhas; produz a heparina, um anticoagulante do sangue; armazena vitaminas; e está implicado no metabolismo hormonal.

Romer e Parsons (1985) comentam que todos os vertebrados possuem um fígado definido, a víscera mais volumosa que sempre ocupa uma área considerável na parte mais ventral e anterior do abdome. Como se observa na história embrionária, o fígado se desenvolve a partir de uma evaginação do tubo digestivo, no mesentério ventral, abaixo da parte do intestino e, portanto, é revestido pelo epitélio celomático. Os autores citam que o fígado permanece ligado ao estômago por uma parte do mesentério ventral que nos mamíferos é denominado de omento menor. Na superfície inferior do fígado, uma parte remanescente do mesentério ventral, o ligamento falciforme, liga-o à parede ventral do corpo. A sua principal fixação, contudo, situa-se na superfície anterior.

Nos vertebrados inferiores desenvolve-se um septo transversal separando a cavidade pericárdica do celoma remanescente; nos mamíferos este septo é incorporado ao diafragma em toda a sua extensão ou por um estreito ligamento coronário - de onde se projeta para trás expandindo-se na cavidade abdominal (ROMER; PARSONS, 1985).

Morfologicamente, o fígado apresenta pouco interesse. Não possui forma constante; uma quantidade suficiente de massa e um arranjo interno adequado, ao nível microscópico, de suas células e vasos sangüíneos, é tudo o que é necessário para seu funcionamento (ROMER; PARSONS, 1985). Hildebrand (1995) relata que o fígado tende a ser lobulado e que são freqüentes dois lobos principais. Entretanto, os lobos podem estar um ao lado do outro, ou um em frente ao outro e o órgão pode não ser lobulado ou apresentar muitos arranjos, numa 
variedade de padrões que não têm funcionalidade conhecida ou significado sistemático. Romer e Parsons (1985), por sua vez, comentam que na maioria dos casos desenvolvem-se lobos direito e esquerdo mais ou menos distintos, mas, nas cobras e nos animais de forma semelhante, muitas vezes este órgão não é dividido e possui forma alongada. As particularidades quanto ao arranjo e disposição dos lobos variam grandemente de espécie para espécie e mesmo em indivíduos da mesma espécie. Os autores afirmam ainda que o fígado acomoda a sua forma àquela das outras vísceras, expandindo-se em qualquer parte da cavidade abdominal não utilizada por outras estruturas.

Em peixes, a partir de uma visão anatômica macroscópica, a forma do fígado é extremamente variável, assim como em outros animais, não somente inter-especificamente, mas também em diferentes indivíduos da mesma espécie (ROUX, 1922). De acordo com o mesmo autor, o tecido do fígado costuma ocupar o espaço intracavitário entre a parede do corpo, o intestino, o baço, a vesícula biliar e o pâncreas; ele forma um molde do espaço que ocupa. Essa afirmação pode ser considerada exagerada, pois, na verdade, o fígado acomoda-se entre os órgãos da parte anterior da cavidade do corpo, como citado anteriormente por Romer e Parsons (1985); sua forma, especialmente em peixes, parece ser, pelo menos parcialmente, determinada pelos órgãos que o cercam, porque a extremidade anterior de diversas dobras intestinais e às vezes um grande número de apêndices pilóricos são forçados profundamente contra ele.

$\mathrm{Na}$ carpa (Cyprinus carpio), o fígado apresenta dois lobos principais. O lobo direito (lobus principalis dexter) que cerca a vesícula biliar e é denominado de "fóvea da vesícula biliar"; e o lobo principal esquerdo (lobus principalis sinister), localizado do lado oposto ao direito, que empurra o baço, formando uma depressão nesta parte do fígado, a "impressão lienal", possibilitando a acomodação do baço nessa depressão. Este lobo é, portanto, designado "lobo do baço". O esôfago e a origem do intestino delgado encontram-se entre os 
lobos principais do fígado. Nesse ponto, uma secção relativamente larga do intestino corre em direção à parede ventral da cavidade corpórea e os "lobos do fígado" unem-se dorsalmente a ela, formando assim o centro hepático ou lobo central. Caudalmente, o fígado forma dois lobos adicionais, "lobos menores", o lobo ventrolateral e o lobo caudal. No lobo principal esquerdo do fígado da carpa, todavia, duas porções são quase sempre desligadas do resto do órgão pelas alças intestinais, cujo curso é pouco variável (AMLACHER, 1954). O autor designa estas porções como "lobos secundários"; esta variação anatômica demonstra a irregularidade na forma do fígado, o que também é observado no bagre africano (Clarias gariepinus) (NAWAR, 1955). Dados precisos ainda não estão disponíveis no que diz respeito à forma que este órgão assume em outros peixes.

\subsection{FÍGADO (ASPECTOS MICROSCÓPICOS)}

De forma geral, o fígado em peixes é, histologicamente, uma glândula retículo-tubular. Seus tubos glandulares não estão dispostos paralelos entre si, mas geralmente formam uma rede emaranhada com aspecto de uma tela. As células do fígado são arranjadas para formar esses tubos; existem cinco a seis células em cada secção transversal de um tubo, e cada célula, individualmente, assume a forma de um setor de um círculo. As paredes nas extremidades das células, isto é, no centro do tubo, não estabelecem contato uma com a outra, mas sim deixam um espaço livre entre si, caracterizando o capilar da bile. A bile flui através desse lúmen em sua saída do fígado (HARDER, 1975).

Cada tubo é circundado por um número de capilares sangüíneos que derivam das veias-porta; eles interpenetram a massa inteira do fígado. A rede de capilares sangüíneos é, portanto, inter-emaranhada com a rede formada pelos tubos do fígado. Os capilares fundem-se simultaneamente para dar origem aos vasos sangüíneos maiores, que finalmente formam a 
veia hepática. O sangue que é filtrado através do fígado flui para o coração nessas veias (HARDER, 1975).

Hampton et al. (1988) e Hampton, Lantz e Hinton (1989) comentam que nos peixes, os hepatócitos formam túbulos associados a células biliares. Entre os ductos biliares e os túbulos de hepatócitos existem canais intermediários que são denominados pré-dúctulos biliares. As células que os compõem são chamadas células epiteliais pré-ductulares biliares ou CEPDBs, comparáveis aos canais de Hering, mas que se situam no interior dos túbulos dos hepatócitos. Acredita-se que as CEPDBs sejam as células-fontes de hepatócitos e de células de ductos biliares em fígado de peixes e sejam equivalentes às células ovais de mamíferos, sendo facilmente diferenciadas das outras células do parênquima por expressarem citoqueratinas AE1/AE3 (BUNTON, 1993; OKIHIRO; HINTON, 2000).

Santos (2003), em sua dissertação de mestrado conclui que o fígado do Clarias gariepinus é revestido pelo epitélio pavimentoso simples (mesotélio) apoiado sobre uma lâmina de tecido conjuntivo denso, formando uma cápsula serosa. No interior do parênquima hepático, os aglomerados maiores de fibras colágenas são encontrados apenas ao redor de vasos maiores ou ductos biliares, sem perceber-se tecido conjuntivo interlobular delimitando os lóbulos, como nos mamíferos. Os ramos da veia porta, da artéria hepática e do ducto biliar raramente são encontrados formando um conjunto; assim, não há uma estrutura comparável ao espaço-porta dos mamíferos. Devido à ausência de um espaço-porta bem definido, o autor adotou outros critérios já sugeridos na literatura para diferenciar a veia central, ou o ramo da veia hepática, além dos ramos da veia porta. Santos (2003), comenta ainda que os ramos da veia porta geralmente são maiores, apresentando sangue em sua luz, e possuem mais tecido conjuntivo em sua camada adventícia, sendo este o seu aspecto mais típico. A veia porta parece estar no centro das irradiações dos cordões de hepatócitos, ao contrário do que ocorre 
em mamíferos, nos quais essa irradiação acaba na veia central, também chamada, veia hepática.

Os hepatócitos formam cordões delimitados por vasos sinusóides que irradiam da veia porta. Entre os cordões, ocasionalmente, pequenos ductos biliares podem ser observados. Estes não são freqüentes no parênquima hepático. Os cordões de hepatócitos e os vasos sinusóides se dirigem para várias veias hepáticas dispersas pelo parênquima. Os hepatócitos são células grandes, com núcleo grande e arredondado apresentando um nucléolo evidente. $\mathrm{O}$ citoplasma apresenta-se vacuolizado e ligeiramente basófilo; os vacúolos provavelmente representam gotículas de lipídios ou material energético de reserva. Entre os hepatócitos podem ser observados núcleos menores e alongados que podem formar um canal arredondado de parede delgada. Os ductos biliares são formados por epitélio cúbico circundado por tecido conjuntivo; melanomacrófagos podem ser encontrados próximos a estas estruturas (SANTOS, 2003).

\subsection{CIRCULAÇÃO SANGÜÍNEA EM PEIXES}

Embora a literatura disponível (nacional e internacional) sobre as atividades aqüícolas seja abundante, principalmente as que se referem aos aspectos da biologia e cultivo de peixes de água salgada e doce, muitas espécies piscícolas ainda necessitam de estudos mais acurados, principalmente relacionados às variações anátomo-funcionais que são constantemente observadas em exemplares de uma mesma espécie, quanto mais as encontradas entre diferentes espécies de um mesmo gênero.

Dentre as variações mais comuns estão àquelas relacionadas às particularidades do sistema circulatório, apesar de que, por vezes, os peixes podem apresentar características muito primitivas e bastante simplificadas quanto à distribuição vascular desse sistema. 
Segundo Orr (1986), dos ciclóstomos aos teleósteos, com exceção dos dipnóicos, o sistema circulatório dos peixes é essencialmente um sistema simples, no qual apenas o sangue não-oxigenado passa pelo coração. Em seguida, é bombeado para as brânquias, oxigenado, e distribuído para o corpo. O coração possui quatro câmaras, mas somente duas delas (o átrio e o ventrículo) correspondem às quatro câmaras (átrios pares e ventrículos pares) dos vertebrados superiores. A primeira câmara do coração de um peixe, ou câmara receptora, é chamada de seio venoso. Tem uma parede fina como a câmara seguinte, o átrio, para o qual o sangue passa. Do átrio, o sangue passa para o ventrículo, que tem paredes espessas, e é bombeado para fora, passando do cone arterioso para a aorta ventral. O sangue da aorta ventral vai para a região branquial para ser oxigenado, passando pelos vasos branquiais aferentes, depois disso, sai das brânquias através das alças coletoras eferentes e vai para a aorta dorsal. Estes vasos são derivados dos arcos aórticos, que ligam as aortas ventral e dorsal. Bond (1996) comenta que o coração (Anexo D) dos peixes normalmente está localizado em uma cavidade pericárdica sob ou logo atrás das brânquias.

Há vários sistemas venosos importantes nos peixes. Entrando no seio venoso de cada lado, há um vaso conhecido como veia cardinal comum ou ducto de Cuvier, que é formado pela fusão das cardinais anteriores e posteriores. O sangue da cabeça é coletado pelas cardinais anteriores e o sangue dos rins e das gônadas é coletado pelas cardinais posteriores. As veias abdominais laterais pares, que recebem o sangue da parede do corpo e dos apêndices pares, também entram nos ductos de Cuvier (ORR, 1986). O autor comenta ainda que nos teleósteos, as veias abdominais não existem, de forma que o sangue das subclávias, que drenam os apêndices peitorais, entra no seio venoso e o sangue proveniente das veias ilíacas, que drenam os apêndices pélvicos, passa para as pós-cardinais.

Em linhas gerais, para que a circulação em peixes seja complementada existem ainda dois sistemas de extrema importância: o sistema porta hepático e o sistema porta renal. Harder 
(1975), comenta que o sistema porta hepático é bem desenvolvido em peixes assim como em outros vertebrados. Todo o sangue que é fornecido para os órgãos da cavidade corpórea pela artéria intestinal e suas artérias tributárias é recebido através das veias porta-hepática e precisa passar através do fígado. Não existe nenhum desvio ao redor desse órgão, tal como aquele que ocorre no sistema porta-renal. Do fígado, o sangue é conduzido pela veia hepática ao seio venoso. Nos Elasmobrânquios existe um seio hepático em cada veia hepática, que se localiza entre o fígado e o coração. O sangue da bexiga natatória e das gônadas também é conduzido para o sistema porta hepático. Os peixes não têm uma única veia porta hepática, mas, preferivelmente, existem duas ou três conexões venosas entre a rede circulatória do trato digestivo e do fígado. Nos Ciprinídeos existe uma variação difusa do sistema porta hepático em que numerosas veias correm entre várias porções do trato digestivo e do fígado. O sistema porta hepático às vezes comunica-se secundariamente com as veias caudais. Nesse caso, parte do sangue das veias caudais passa através do sistema porta hepático e parte do sistema portarenal (HARDER, 1975).

\subsection{SISTEMA PORTA HEPÁTICO EM PEIXES EM GERAL E EM Clarias gariepinus}

Para facilitar a compreensão dos leitores e proporcionar um estudo comparativo entre o sistema porta hepático padrão em peixes e aquele encontrado em Clarias gariepinus, procurou-se relatar os dados bibliográficos acerca deste sistema da maneira mais aprofundada possível dentro das possibilidades que a bibliografia relacionada ao assunto nos proporcionou, conforme as subseções abaixo. 


\subsubsection{Sistema Porta Hepático em Peixes}

O sistema porta de Ophiodon elongatus foi estudado por Allen (1905) através da dissecação em vasos injetados com gelatina corada. Segundo o autor, esse sistema de veias retorna a maior parte do sangue venoso do estômago, baço, ceco e intestino. Todavia, parte do sangue da região posterior do estômago e intestino, alcança a veia cardinal direita através da veia mesentérica posterior. Esta veia se anastomosa com o sistema porta em pelo menos dois lugares. Em Ophiodon, existem duas veias porta distintas, que terminam nos lobos esquerdo e direito do fígado. A porta direita retorna o sangue do lado direito do estômago, baço, e uma porção do intestino, enquanto a porta esquerda drena o ceco, a porção ventral do estômago, e uma porção do intestino. Em Ophiodon, esses dois sistemas permanecem bem separados; todavia, seus ramos anastomosam-se em diversos lugares na região da terminação posterior do estômago, mas, dentro do fígado, nenhum de seus ramos se une. Cada uma das veias porta fragmenta-se em capilares em seu respectivo lobo, que se reúnem formando as veias hepáticas, esquerda e direita, e estes vasos unem-se em um seio antes de desembocar no seio venoso.

Em Ophiodon, o tronco-porta direito é caracteristicamente um vaso muito curto sendo sua fonte originária de dois troncos principais: um deles a própria veia gástrica direita vinda do estômago, e o outro ramo, uma veia formada pela união da veia intestinal com a veia esplênica. A veia gástrica direita tem sua origem na porção cardíaca ou posterior do estômago, onde se anastomosa com um ramo " $z$ " da veia mesentérica posterior, e com a veia gástrica posterior, que é um ramo da porta esquerda. O curso da veia gástrica direita é cefálico, sob a artéria gástrica direita e o ramo gástrico direito do vago. Por toda a extensão de seu curso ela recebe numerosos ramos das camadas musculares do estômago. Saindo da parte anterior do estômago ela cruza sobre a artéria e o nervo correspondentes, e a artéria celíaca, e 
quando alcança a metade do caminho entre o estômago e a extremidade caudal do lobo direito do fígado, diretamente atrás de um corpo com aparência de glândula marcado como "g”, ela se une com a veia intestinal. Esta usualmente origina-se na região do reto para anastomosar-se com o ramo "y" da veia mesentérica posterior. Em seu curso cefálico no tecido adiposo ao redor do intestino, abaixo da artéria correspondente, ela ordinariamente envia de um a três ramos, que são drenados na veia cecal direita ou em seu ramo gástrico posterior. No espécime que originou a figura 1 do estudo de Ophiodon, esses 3 vasos estavam presentes. Os dois vasos posteriores foram drenados na veia gástrica posterior direita e o vaso anterior, na veia cecal direita. A veia intestinal, por todo o seu percurso, recebe numerosos ramos do intestino, e uma grande veia daquele órgão. A veia esplênica origina-se no centro do baço vinda de um sistema de vasos flabeliformes, que se unificam em uma haste comum, que deixa a parte anterior do baço com a artéria esplênica e logo se drena na veia intestinal. Imediatamente após receber a veia esplênica, a veia intestinal geralmente envia ou recebe uma veia de conexão que se une com a veia duodenal ou veia intestinal anterior, um ramo da porta esquerda. Foi observado em outro espécime que esta veia se origina da esplênica, em vez da veia intestinal. A veia intestinal termina unindo-se à veia gástrica direita, na região do lobo direito do fígado, para formar o tronco-porta direito principal. Como havia sido relatado anteriormente, este vaso é, em si mesmo, um tronco muito curto que penetra o ápice do lobo direito do fígado, e se esgota naquela glândula e fragmenta-se em numerosas veias interlobulares, que finalmente terminam em numerosos capilares venosos (ALLEN, 1905).

Em poucas palavras, antes de entrar no fígado, todavia, a porta direita recebe uma veia de um corpo com aparência de glândula, assinalado como "g" na figura I, e uma veia da vesícula biliar anterior. Este vaso se origina da parte anterior da vesícula, e, semelhante à artéria correspondente, anastomosa-se com a veia da vesícula biliar posterior (ALLEN, 1905). 
Em alguns casos, como já havia sido notado na artéria correspondente, a veia intestinal não apresenta sempre sua origem no reto, anastomosando-se com a veia mesentérica posterior e com os vasos que a constituem, e esvaziando-se na veia cecal direita; mas, às vezes, originase muito mais cefálica, e a parte do intestino usualmente drenada por este vaso, é despejada na veia mesentérica posterior, com as veias que a compõem drenando-se na veia cecal direita (ALLEN, 1905).

Em Ophiodon, a veia porta esquerda é um pouco maior dentre as duas portas; ela tem sua fonte principalmente nas veias ceco-pilóricas esquerda e direita e na veia intestinal. Das duas veias ceco-pilóricas, a direita é a maior. Além de receber três ou quatro ramos maiores vindos do ceco, recebe uma veia gástrica posterior esquerda e uma direita. $\mathrm{O}$ vaso direito vem do lado ventral e direito da porção cardíaca ou posterior do estômago, onde seus ramos anastomosam-se com os da veia gástrica direita, e com o ramo " $z$ " da veia mesentérica posterior. No espécime que originou as figuras 1 e 6 do estudo de Ophiodon a veia gástrica posterior direita recebeu dois ramos da veia intestinal, e a veia ceco-pilórica direita recebeu um terceiro. Em outros espécimes em que esses vasos se unem tanto com a veia intestinal como com a veia ceco-pilórica direita, ou com seu ramo gástrico posterior, seria possível que o sangue fluisse em uma das direções, mas é provável que a menor resistência seja concernente à veia ceco-pilórica. Em poucas palavras, antes que a veia ceco-pilórica direita se una à esquerda em frente ao piloro, ela recebe uma veia pequena do piloro. Usualmente, a veia ceco-pilórica esquerda é a menor de todas. Ela recebe cerca de dois ramos do ceco e um ou dois pequenos ramos do piloro. Tanto as veias ceco-pilóricas correm fora de suas artérias correspondentes quanto se unem na formação do tronco-porta esquerdo diretamente em frente o ponto de bifurcação da artéria celíaca. Perto de sua origem na união das duas veias cecopilóricas, a porta esquerda, ou, ocasionalmente, a veia ceco-pilórica direita, recebem a veia intestinal. Esta veia tem, usualmente, sua fonte do lado ventral do intestino, nas proximidades 
do reto. Seu curso é cefálico no tecido adiposo sob o intestino. Antes de ir tão longe, todavia, ela cruza para o lado superior do intestino, mudando de posição com a veia intestinal. Então, prosseguindo cefálica sobre a artéria até o duodeno ser alcançado, ela cruza sobre o intestino, a artéria intestinal, a veia intestinal, a parte anterior do duodeno, a artéria celíaca, e drena-se na porta esquerda nas proximidades de sua origem nas duas veias ceco-pilóricas. Continuando cefálica, por uma curta distância, entre o estômago e o fígado e à esquerda da artéria celíaca, a porta esquerda recebe a veia duodenal ou intestinal anterior, que retorna o sangue da alça anterior. $\mathrm{O}$ curso deste vaso é, em princípio, imediatamente atrás da artéria correspondente; então, depois de passar por baixo da artéria intestinal e da veia intestinal, ela, ordinariamente, emite ou recebe a veia conectora, uma pequena veia que usualmente se anastomosa com a veia intestinal, um ramo da porta direita. Então, depois de passar sobre o braço anterior do duodeno, de quem recebe um ramo, cruza a artéria celíaca e, depois de seguir por trás da artéria hepática por uma curta distância, termina na porta esquerda. A porta esquerda penetra a superfície dorsal do fígado por meio de cinco grandes ramos, terminais ou radicais, designados pelas letras de "a" até "e". Estes vasos penetram imediatamente o grande lobo esquerdo do fígado e se fragmentam em veias interlobulares que, por sua vez, fragmentam-se em capilares venosos. Usualmente, diversas veias da superfície ventral do estômago, designadas como veias gástricas ventrais, drenam-se em alguns destes radicais, e, algumas das veias gástricas ventrais freqüentemente penetram a superfície dorsal do fígado e fragmentamse em capilares venosos não sendo drenadas diretamente no sistema porta. A veia da vesícula biliar posterior, que se origina na superfície dorsal superior da vesícula e se anastomosa com a veia anterior da vesícula biliar, drena-se no radical "a" da porta esquerda. Este radical pode também receber uma veia similar, mas menor, da superfície ventral da vesícula (ALLEN, 1905). 
Um vaso interessante em Ophiodon é a veia gástrica esquerda, visto que ela não é conectada ao sistema porta, mas termina diretamente na pré-cava. Esta veia tem sua origem em dois ramos do lado esquerdo do estômago, em um dos lados da artéria gástrica esquerda. O ramo ventral é usualmente o maior; originando-se da terminação posterior extrema do estômago, seus ramos anastomosam-se com os do ramo "z" da veia mesentérica posterior. Quando a porção anterior do estômago é alcançada, o ramo gástrico esquerdo menor cruza sobre a artéria gástrica esquerda, e se une ao tronco principal da veia gástrica esquerda, e o combinado avança sobre o ramo gástrico do vago e drenam-se na pré-cava. Uma outra pequena veia gástrica origina-se da superfície dorsal anterior do estômago e termina na précava, sobre a veia gástrica esquerda principal (ALLEN, 1905).

Como em outros vertebrados, a veia intestinal, a gástrica e a cecal originam-se de capilares nas camadas de tecido conjuntivo das criptas e os ramos maiores correm nas camadas musculares. Dentro do fígado, os ramos terminais ou radicais das duas portas esgotam-se a si próprios nas veias interlobulares, que se fragmentam em capilares venosos, que se reúnem na formação das veias interlobulares ou centrais, das quais as veias sublobulares têm sua origem. Estes vasos são os radicais que, unindo-se, formam as duas veias hepáticas, que procedem dos lobos esquerdo e direito, respectivamente, e desembocam em um seio hepático que penetra o seio venoso posterior. No fígado, os troncos principais do sistema hepático situam-se sob àqueles do sistema porta (ALLEN, 1905).

Como nas artérias, a maioria das variações das veias neste grupo ocorre nas vísceras. Independentemente disso, todas as espécies examinadas tinham uma porta esquerda e uma direita distinta que se fragmentam nos lobos esquerdo e direito, respectivamente. Em Sebastodes, ambas as portas terminam em uma porta comum. Em Hexagrammos, a porta direita anastomosa-se com o radical "a" da porta esquerda. Em Scorpaenichthys, esta união algumas vezes ocorre, mas com o Ophiodon, ela nunca foi observada. Todavia, tanto em 
Ophiodon como em Scorpaenichthys, existe uma veia de conexão que interliga estes dois sistemas na região do baço (ALLEN, 1905).

\subsubsection{Sistema Porta Hepático em Clarias gariepinus}

Nawar (1955) estudou o sistema porta hepático em Clarias lazera (sinonímia de Clarias gariepinus) utilizando a técnica de injeção de celoidina, obtendo moldes do sistema vascular. Segundo o autor, a veia porta hepática origina-se no mesentério, dorsal ao reto, como a veia retal (rc), drenando o reto através de numerosos pequenos vasos (d). Ela anastomosa-se com a veia porta renal pelas veias $(\mathrm{j}, \mathrm{k}, \mathrm{e} \mathrm{l})$, que atravessam o tecido renal. Ela avança e curva-se para a esquerda, e então levemente para a direita, para unir-se à veia mesentérica (mes.), formando, assim, a veia porta hepática (hp. pr.).

A veia mesentérica (mes.) situa-se dorsal ao intestino, no mesentério, que a une à superfície ventral do rim mediano. Ela recebe cerca de 15 veias intestinais (a . int.), que drenam o intestino. Sua extremidade posterior curva-se para a esquerda, e então corre anteriormente para unir-se à veia retal, enquanto sua extremidade anterior recebe a veia comum (g) dos primeiros dois vasos intercostais direitos, que, parcialmente, distribuem seu sangue ao rim por um ramo (h). Ele envia uma veia ao lobo separado direito do fígado, em que é dividido em quatro ramos principais. Então continua seu trajeto adiante, penetra o lobo mediano direito do fígado, em que ela se ramifica em alguns pequenos vasos (f), e anastomosa-se com a veia porta hepática no tecido do fígado através da veia anastomótica (as) (NAWAR, 1955).

A veia porta hepática (hp. pr.) corre anteriormente e passa sobre a superfície ventral do baço, do qual recebe 5 veias esplênicas (sp.), e então, 5 pequenas veias (c.) da parte pilórica do estômago e uma grande veia gástrica (gs) da parte cardíaca do estômago e da vesícula 
biliar. Ela envia uma veia (b.) ao lobo separado esquerdo do fígado em que é dividida em 4 ramos principais. Ela então penetra o lobo mediano esquerdo do fígado, em que é dividida em muitos ramos (a .) (NAWAR, 1955).

A circulação no sistema porta hepático ocorre, principalmente, através da veia porta hepática do lado esquerdo e, parcialmente, através da veia mesentérica do lado direito. O ciclo é completado através da veia anastomótica (as) (NAWAR, 1955).

\subsubsection{Veias Hepáticas}

De acordo com Nawar (1955), a veia hepática (hp) em Clarias lazera origina-se em cada lado do lobo separado do fígado, de quem coleta o sangue por cerca de 8 vasos (b). Ela recebe dois ramos da tira de tecido do fígado que liga o lobo separado ao fígado mediano. Ela então corre, antero-medianamente, sobre a superfície dorsal do lobo mediano do fígado, de quem recebe 5 vasos pequenos e um maior (a .). Próximo à sua extremidade anterior, recebe 3 veias (c) que coletam o sangue do corno anterior do lobo mediano do fígado. Centenas de vênulas (d) abrem-se diretamente nele. As duas veias hepáticas passam através do septo pericárdico-peritonial e abrem-se diretamente no seio venoso. 


\section{MATERIAL E MÉTODO}

Para melhor compreensão dos materiais utilizados neste trabalho de pesquisa, bem como, da metodologia adotada para o uso destes materiais e a execução das diversas técnicas anatômicas preconizadas pelo projeto, descrevemos os materiais separadamente da metodologia adotada.

\subsection{MATERIAL}

Todos os insumos necessários à execução das técnicas que foram utilizadas nesse trabalho estão discriminados e descritos nas subseções abaixo:

\subsubsection{Peixes}

Para o estudo do sistema porta hepático de Clarias gariepinus, conhecido popularmente como bagre africano, foram utilizados 16 exemplares adultos da referida espécie, todos do sexo feminino, com idade aproximada de um ano e meio, que apresentaram comprimento total entre 45 e $53,5 \mathrm{~cm}($ mediana $=48,64 \mathrm{~cm})$ e massa corpórea entre 575 e 1068 gramas (mediana $=812,67$ gramas).

Os peixes foram identificados a partir da chave proposta por Teugels (1986); a classificação atual é a seguinte:

Superordem - Ostariophysi

Ordem - Siluriformes

Família - Clariidae

Gênero - Clarias 
Subgênero II - Clarias (Clarias) Scopoli, 1777.

\section{Espécie - gariepinus}

Todos os espécimes provieram do Centro Nacional de Pesquisa em Peixes Tropicais (CEPTA), na cidade de Pirassununga, SP, e foram trazidos ao biotério do Instituto de Ciências Biomédicas (ICB) da Universidade de São Paulo, onde aguardaram a execução de diferentes técnicas anatômicas.

As técnicas envolveram anestesia, injeção de substâncias recomendadas ao estudo do sistema vascular (látex, nanquim, cloreto de polivinil $^{1}$ e substância radiopaca), dissecção, corrosão ou radiografia, conforme exigência de cada técnica, e ainda, o estudo da composição histológica do fígado desse animal.

Os 16 exemplares utilizados na experimentação foram submetidos às diferentes técnicas supracitadas. Deste contingente, 14 receberam injeções vasculares via sistema arterial ou venoso, sendo 10 de látex e/ou nanquim, um de contraste radiopaco e três de vinilite (Anexo Z). Outros dois foram utilizados para coleta de material para o exame histológico.

\subsubsection{Manutenção}

Os bagres foram mantidos em tanques de fibra de vidro, com capacidade de $1000 \mathrm{~L}$. Os tanques receberam aeração e filtragem adequadas a uma lotação máxima de cinco indivíduos. O cuidado referente à manutenção adequada da densidade de animais por tanque foi indispensável, pois, com uma lotação compatível à indicada evitou-se problemas com a adaptação dos animais, como alteração da pigmentação corpórea, lesões cutâneas, tentativas de fuga e perda de apetite.

\footnotetext{
${ }^{1}$ Vinilite $\mathrm{VMCH}^{*}$ Union Carbide
} 
A alimentação dos peixes constou, exclusivamente, no uso de ração peletizada ${ }^{2}$ (Nutripeixe Terminação SI), atendendo as exigências nutricionais da espécie. O alimento foi fornecido diariamente, e em quantidade aproximada de $100 \mathrm{~g}$, o suficiente para garantir o suprimento alimentar dos animais em função da demanda diária observada em cada tanque.

\subsubsection{Solução Anestésica}

Os peixes foram sedados e anestesiados com etil-aminobenzoato (benzocaína). Para os procedimentos de manipulação, sem intervenção cirúrgica, utilizou-se a concentração de 25 $\mathrm{mg} / \mathrm{L}$; porém, durante as atividades de manuseio com intervenções cirúrgicas, elevou-se para $50 \mathrm{mg} / \mathrm{L}$, alcançando-se o estágio de narcose profunda. Tal medida objetivou impedir que os peixes sofressem estresses circulatórios que prejudicassem os resultados das angiotécnicas.

Os cuidados com a preparação da benzocaína foram aqueles preconizados por Green (1979), enfatizando a necessidade de os peixes serem jejuados por 24 a 48 horas antes da anestesia, pois, do contrário, eles poderiam vomitar, prejudicando a higiene do sistema de circulação de água utilizada na mesa cirúrgica.

\subsubsection{Solução Perfusora}

Para contribuir com a retirada do sangue e facilitar o processo de perfusão cada exemplar recebeu, após sedação leve com benzocaína em recipiente específico, uma injeção intraperitoneal com 500 UI de heparina sódica ${ }^{3}$.

\footnotetext{
${ }^{2}$ Cargill, Incorporated - Purina ${ }^{\circledR}$

${ }^{3}$ Liquemine ${ }^{\circledR}$ Roche
} 
Cada animal foi perfundido com cerca de $200 \mathrm{ml}$ de solução fisiológica contendo 20 $\mathrm{UI} / \mathrm{ml}$ de heparina. Todos esses cuidados garantiram a isenção total de sangue no sistema vascular dos peixes.

\subsubsection{Solução Fixadora Específica}

Os peixes destinados à coleta de fragmentos do fígado para exame histológico também foram perfundidos com a solução perfusora, e, na mesma seqüência, com as soluções fixadoras de Bouin ou McDowell.

A solução fixadora de Bouin foi preparada para que atingisse uma concentração de 2,5\% de formol. Para cada $100 \mathrm{ml}$ dessa solução, foram utilizados $75 \mathrm{ml}$ de ácido pícrico, 25 $\mathrm{ml}$ de formol a $40 \%$ e $5 \mathrm{ml}$ de ácido acético glacial. Os fragmentos do fígado coletados para análise permaneceram nessa solução por 24 horas e, em seguida, foram mantidos em álcool $70 \%$ até o momento do processamento.

A solução de Mc Dowell foi composta de glutaraldeído a 1\% e paraformaldeído a 4\%, em tampão fosfato $(0,1 \mathrm{M}$ e pH 7,2); após a perfusão do peixe submetido a essa técnica, os fragmentos do fígado foram extraídos e incluídos em historesina.

\subsubsection{Solução Fixadora-Descalcificadora}

Os espécimes destinados à dissecação foram fixados e descalcificados em uma solução contendo $30 \mathrm{ml}$ de ácido acético, $40 \mathrm{ml}$ de ácido clorídrico, $80 \mathrm{ml}$ de formaldeído, $100 \mathrm{ml}$ de clorofórmio, $100 \mathrm{ml}$ de água de torneira e $200 \mathrm{ml}$ de álcool a 95 GL, Behmer et al. (1976), onde permaneceram por 15 a 20 dias até que seus ossos, especialmente aqueles da cabeça, adquirissem consistência mole, com aspecto de tecido tendíneo. 


\subsubsection{Cânulas}

As cânulas utilizadas para perfusão e injeção foram distintas quanto às dimensões. A perfusão foi realizada utilizando-se uma sonda uretral $n^{\circ} 6$ introduzida na veia (v.) caudal do peixe, conduzindo, em fluxo contínuo, a solução perfusora, enquanto o sangue era eliminado via artéria (a .) caudal. Para a injeção do sistema arterial usou-se um tubo de polietileno flexível com diâmetro externo de $1 \mathrm{~mm}$, com uma das extremidades adaptadas a uma agulha hipodérmica, facilitando a manipulação.

Os procedimentos de injeção do sistema venoso foram executados utilizando cânulas do tipo sonda uretral $\mathrm{n}^{\mathrm{o}} 6$, acopladas a uma seringa hipodérmica de material plástico com capacidade de $10 \mathrm{ml}$ de volume total (para as injeções com látex, nanquim ou sulfato de bário).

Para as injeções com vinilite, utilizou-se uma cânula metálica constituída de agulha hipodérmica não-descartável (sem bizel), com diâmetro externo de 1,4 mm, engatada a uma seringa de vidro com capacidade de $10 \mathrm{ml}$ de volume total, lembrando que os peixes preparados por essa técnica também foram perfundidos previamente, seguindo o mesmo procedimento utilizado para os espécimes injetados com látex.

\subsubsection{Mesa Cirúrgica}

A mesa cirúrgica (Anexo E), indispensável aos procedimentos de canulação e injeção vascular dos peixes, foi dimensionada de tal forma que permitisse a acomodação do animal em decúbito dorsal, possibilitando sua manipulação fora d'água, em estado de narcose profunda. 


\subsubsection{Substâncias de Injeção}

Para melhor compreensão das pessoas que consultarem esse trabalho, procurou-se descrever, detalhadamente, as substâncias de injeção utilizadas nas diferentes técnicas preconizadas nesse projeto.

\subsubsection{Látex}

A principal substância utilizada para injeção dos bagres com o objetivo de distinguir seus vasos sanguíneos, e, após sua polimerização, permitir o preenchimento vascular identificado depois da dissecação dos peixes, foi o látex natural centrifugado.

Essa substância, utilizada para as injeções do sistema arterial e venoso, foi coada, em gaze, antes de cada aplicação, e corada com pigmentos azul, vermelho ou amarelo vendidos em casas comerciais na forma de bisnaga como corantes líquidos para tinta à base de $\mathrm{PVA}^{4}$. $\mathrm{A}$ variação na cor do látex foi determinada em função do sistema a ser injetado, bem como do tipo de contraste a ser dado em determinada peça anatômica.

Em geral, foram utilizados cerca de 4 a $13 \mathrm{ml}$ de látex em cada peixe dependendo do sistema a ser injetado; ele foi aplicado com seringa hipodérmica de material plástico, com capacidade de 5 a $10 \mathrm{ml}$ de volume total.

\footnotetext{
${ }^{4} \mathbf{X a d r e z}$ - Empresa Globo Tintas.
} 


\subsubsection{Gelatina}

A gelatina ${ }^{5}$ utilizada foi do tipo comestível sob a forma de pó incolor e sem aditivos. Inicialmente foi embebida e dissolvida em água destilada, na proporção de uma parte de pó para 25 partes de água. Posteriormente, a massa foi fundida em banho-maria a $60^{\circ} \mathrm{C}$. Em decorrência dessa fusão, a mistura apresentou o aspecto de gel. Em seguida, foi resfriada ao ar livre até chegar ao estado de solidificação. Manteve-se o estado sólido, em geladeira, a $4{ }^{\circ} \mathrm{C}$, durante 10 horas. Novamente, a gelatina foi fundida a $40^{\circ} \mathrm{C}$ e adicionada ao nanquim, até atingir 5\% do volume deste (INTELIZANO, 1999).

Para aplicação do sulfato de bário e posterior estudo radiográfico de Clarias gariepinus, utilizou-se uma solução composta por $50 \%$ de sulfato de bário ${ }^{6}$ e $50 \%$ de gelatina (preparada da mesma forma descrita no parágrafo anterior), que foi injetada através da veia caudal do peixe escolhido para a técnica de radiografia. Foram utilizados seis $\mathrm{ml}$ dessa solução para a injeção do peixe $n^{\circ} 8$ (Anexo Z).

\subsubsection{Cloreto de Polivinil (Vinilite)}

As veias que compõem todo o sistema venoso dos peixes foram modeladas por meio da injeção de vinilite solubilizado em acetona, respeitando a proporção de uma parte de vinilite para três de acetona, corado com pigmento azul de laca nitrocelulose ${ }^{7}$, compatível ao utilizado pela indústria automotiva.

Em todas as injeções com vinilite utilizou-se, em média, entre cinco e $10 \mathrm{ml}$ de volume dessa substância, aplicado com o equipamento indicado no item 3.1.6.

\footnotetext{
${ }^{5}$ Gelatina em pó - Dr. Oetker (Rebière Gelatinas Ltda)

${ }^{6}$ Celobar - Laboratórios Beecham Ltda

${ }^{7}$ Empresa Sherwin Williams do Brasil Indústria e Comércio Ltda - Divisão Lazzuril
} 


\subsubsection{Gelatina e Sulfato de Bário}

Utilizou-se como substância radiopaca o sulfato de bário em suspensão aquosa a 50\% preparada de acordo com as orientações do item 3.1.8.2, acrescentado-a ao bário e constituindo $10 \%$ de seu volume.

\subsection{MÉTODO}

Para cada procedimento executado com os peixes que foram submetidos à experimentação, procurou-se descrever, de forma clara, a metodologia utilizada.

\subsubsection{Manipulação, Contenção e Anestesia}

Para possibilitar os procedimentos de manipulação e contenção, os bagres foram inicialmente sedados conforme recomendações previstas no item 3.1.2.

A aplicação do anticoagulante (heparina sódica) (Anexo F) foi possível a partir da sedação leve dos peixes. Para tanto, após o jejum, os animais foram retirados do tanque de manutenção e colocados em um recipiente graduado contendo parte da água do tanque, como recomendado por Jolly, Mawdesley-Thomas e Bucke $^{8}$ (1972 apud GREEN, 1979, p. 232), com concentração de $25 \mathrm{mg} / \mathrm{L}$ de benzocaína.

Após 15-20 minutos, os sinais clínicos da anestesia se tornaram aparentes: desequilíbrio postural, movimentos natatórios menos freqüentes, aumento da freqüência respiratória, diminuição da amplitude dos movimentos respiratórios, suspensão dos reflexos aos estímulos sonoros e perda do tônus muscular, como proposto por (BROWN, 1993).

\footnotetext{
${ }^{8}$ JOLLY, D. W.; MAWDESLEY-THOMAS, L. E.; BUCKE, D. Anaesthesia of fish. Veterinary Record, v. 91, p. 424-426, 1972.
} 
Nessas condições, os peixes receberam a injeção de heparina na dosagem mencionada em 3.1.3, retornando ao tanque de manutenção para reversão da anestesia obtida através da irrigação da cavidade orobranquial, imergindo o peixe na água do tanque e movimentando-o para trás e para frente com sua boca aberta, até que retomassem os sentidos. Os bagres permaneceram cerca de 45 minutos nesse local para readquirirem totalmente os reflexos e metabolizarem a heparina.

Para permitir a injeção, os animais foram novamente colocados no recipiente graduado com anestésico, agora com o dobro da concentração inicial, e depois da observação dos sinais clínicos da anestesia citados acima, os peixes foram deslocados para a mesa cirúrgica (Anexo G), onde o mesmo anestésico foi forçado a irrigar as brânquias, em sistema de fluxo contínuo, mantendo o animal em estado de narcose profunda, como preconizado por (BROWN, 1987).

\subsubsection{Perfusão}

A perfusão foi feita através do vaso sangüíneo denominado veia caudal.

$\mathrm{O}$ vaso $($ Anexo $\mathrm{H})$ situa-se imediatamente dorsal à coluna vertebral, ventral à artéria caudal, disposto paralelamente a esta.

Para alcançar a veia caudal, os peixes foram colocados sobre uma bancada de material não-poroso para que tivessem a cauda seccionada (Anexo I) com o auxílio de um bisturi, na altura de sua porção mediana, próximo aos raios distais da nadadeira dorsal.

O corte transversal foi feito de forma a garantir o rompimento da cute, do peritônio, e dos tecidos musculares, até alcançar a coluna vertebral, procurando-se encaixar a lâmina do bisturi em um dos espaços intervertebrais para romper a medula, retirando-se, dessa forma, a porção médio-distal da cauda tornando visível sua veia caudal, cujo lume era observado a olho desarmado. 
Em seguida, o animal foi colocado em decúbito dorsal sobre a mesa cirúrgica para facilitar a canulação do vaso.

A cânula utilizada para esse procedimento foi a do tipo sonda uretral $n^{\circ} 6$, acoplada a um equipo com soro fisiológico e heparina sódica, na proporção de 20 UI de heparina/ml de soro. Controlando-se o fluxo do soro heparinizado injetado no sistema venoso do peixe, todo o sangue circulante foi substituído, o sistema higienizado e a coagulação sanguínea evitada pela presença da heparina sódica.

Nos peixes destinados à coleta de material para fins histológicos seguiu-se à solução perfusora, a solução fixadora de Bouin ou McDowell.

O ponto de sangria ocorreu através da artéria caudal por sua fácil identificação após a secção completa da cauda do peixe (Anexo J).

Concomitante à perfusão, evidenciou-se um forte empalidecimento da tonalidade vermelha das brânquias. Após 40-45 minutos de descanso, o peixe estava apto a ser injetado.

\subsubsection{Injeção Venosa e Arterial}

Os sítios de canulação e injeção para garantir o preenchimento das veias e das artérias estudadas no trabalho foram, respectivamente, a veia e a artéria caudal.

A veia caudal (Anexo L), como mencionado em 3.2.2, foi de fácil identificação e canulação, devido à posição que ocupa, ao grosso calibre e à resistência de suas paredes, aumentando as chances de preservação da integridade dos vasos sangüíneos que receberiam as substâncias injetadas e diminuindo os riscos de vazamento. O território alcançado por essa via compreendeu basicamente todas as vísceras abdominais.

A artéria caudal, de menor calibre e de paredes menos resistentes foi de fácil identificação, porém de difícil canulação, devido à fragilidade apresentada por este vaso. $\mathrm{O}$ 
volume das substâncias injetadas e a pressão exercida sobre o sistema arterial foram bem menores do que no sistema venoso para minimizar os riscos de vazamento, que são freqüentes naquele sistema. O território alcançado por essa via compreendeu o sistema branquial eferente, a cabeça e as vísceras abdominais mais craniais, além dos vasos que estabelecem uma relação direta com a musculatura do corpo.

Para acompanhar de forma mais acurada as injeções evitando-se o rompimento dos vasos e o refluxo das substâncias, o peixe foi mantido em decúbito dorsal e o abdome incidido (Anexo M) ao longo da linha mediana, desde a base das nadadeiras peitorais até próximo ao ânus. Com o auxílio de pinças, de grampos afastadores metálicos (Anexos N, O e P) e de gaze, aumentou-se o raio de visão sobre as vísceras abdominais observando-se, com clareza, o fluxo das substâncias injetadas. Essa visualização serviu de base para o controle da pressão exercida durante as injeções, aumentando as chances de sucesso.

No sistema venoso foram injetadas três substâncias: látex corado de azul (para posterior fixação e dissecação do animal), vinilite (para subseqüente fixação e corrosão das peças, confeccionando-se moldes anatômicos), e sulfato de bário (como substância radiopaca para exames radiográficos).

No sistema arterial foi injetado o látex corado de vermelho ou de amarelo, ou mesmo o nanquim, sendo também necessárias, a fixação e a dissecação dos peixes.

Para a injeção das veias hepáticas com látex foi usada a via cardíaca retrógrada. Após a perfusão sangüínea o bagre foi colocado em decúbito dorsal. O assoalho da cavidade orobranquial foi tracionado ventralmente aumentando-se a dimensão vertical da cavidade. Os ossos operculares e branquiostegais direitos foram excisados completamente, abrindo-se assim uma via de acesso mais ampla lateralmente. Após a dissecação da mucosa o músculo esterno-hioídeo foi transeccionado transversalmente ao seu ventre que se encontrava distendido. Aprofundando a incisão adentrou-se na cavidade pericárdica. O coração foi 
cortado no sulco átrio-ventricular, expondo seu óstio, que foi prontamente canulado em direção ao átrio, para então ser preenchido com a massa. A seqüência de preenchimento das câmaras foi retrógrada, portanto, seguiu-se ao átrio o seio venoso, onde através dos óstios das v. hepáticas, completou-se a luz das mesmas.

Para qualquer um dos casos, exceto para os peixes injetados com sulfato de bário, após a fixação feita em formalina a $10 \%$ por 72 horas, as peças foram descalcificadas em solução fixadora-descalcificadora por 15 dias para garantir o amolecimento das estruturas ósseas, especialmente dos ossos da cabeça, facilitando as dissecações.

\subsubsection{Preparo das Peças para Dissecação}

Depois de descalcificados, os bagres injetados com látex ou com nanquim, foram preservados em solução alcoólica a 70\%, onde aguardaram o início das dissecações.

No primeiro estágio da dissecação (Anexo Q) os animais sofreram a retirada das paredes laterais e da ventral do corpo (formadas por tecido muscular), das gônadas, das nadadeiras peitorais e dos ossos que protegem ventralmente a cavidade pericárdica, expondo as vísceras de forma geral.

Num estágio posterior, as peças foram reduzidas ainda mais, evidenciando-se, principalmente, o fígado mediano e seus lobos adjacentes, os chamados lobos separados (ou acessórios).

A dissecação propriamente dita, com a exposição dos vasos do fígado, objeto deste estudo, ocorreu num terceiro momento, quando todas as peças injetadas pela mesma via de acesso foram comparadas, na expectativa de identificar possíveis variações anatômicas. 
A maior parte da dissecação ocorreu a olho desarmado, sendo usada uma lupa estereoscópica apenas para elucidar o trajeto dos vasos de menor calibre, que, em alguns casos, se apresentaram após a distribuição dos vasos de maior calibre.

\subsubsection{Angiomodelagem}

A modelagem dos vasos hepáticos foi obtida após a injeção do vinilite via veia caudal.

A contenção e a canulação dos peixes foi aquela descrita no item 3.2.3.

Após o preenchimento das veias, os peixes foram fixados em formalina a 10\% por 72 horas, e, logo em seguida, imersos em solução de ácido acético e ácido clorídrico a 20\%, onde permaneceram por 10 dias, sendo os dois ácidos utilizados na mesma proporção. Essa solução foi usada para promover a corrosão dos tecidos (Anexo R) e a obtenção dos moldes vasculares.

Essa técnica anatômica foi de grande valia para localizar topograficamente os vasos hepáticos, tornando clara a relação estabelecida entre o lobo hepático mediano e os lobos adjacentes.

É importante ressaltar que a precisão dos desenhos esquemáticos sobre a vascularização do fígado só pôde ser alcançada após a comparação das peças injetadas com a análise radiográfica e com os moldes vasculares (Anexo S).

\subsubsection{Exame Radiográfico}

Após a injeção da substância radiopaca, os peixes foram fixados em formalina a 10\% por 24 horas. Em seguida, foram levados ao Setor de Radiologia do Ambulatório Veterinário da Faculdade de Medicina Veterinária e Zootecnia da Universidade de São Paulo, e 
submetidos a dois planos de incidência radiográfica, uma vista dorso-ventral (distância de 1,2 metros; $40 \mathrm{KV}$; 10 ms, e $100 \mathrm{~mA}$ ) (Anexo T), e outra látero-lateral (distância de 1,2 metros; $42 \mathrm{KV} ; 10 \mathrm{~ms}$, e $100 \mathrm{~mA}$ ) (Anexo U).

As radiografias foram utilizadas para avaliar a capacidade de preenchimento do território vascular pelas substâncias de injeção e evidenciar os principais vasos sangüíneos relacionados à circulação hepática.

\subsubsection{Exame Histológico}

Os fragmentos do fígado utilizados para exame histológico (desenvolvido através da imersão destes fragmentos nas soluções fixadoras de Bouin ou Mc Dowell), foram extraídos a partir de três regiões distintas desse órgão: o lobo principal, os lobos separados (ou acessórios) e o istmo (Anexo V), que liga essas duas regiões.

Do lobo principal, foram retiradas duas amostras a partir dos cortes longitudinal e transversal desse lobo. Os lobos separados (Anexo X) e o istmo sofreram um mesmo plano de corte, em sentido transversal, o que proporcionou a composição de mais quatro amostras, sendo duas de cada lado.

O material fixado em Bouin seguiu a rotina de inclusão em parafina e corte em micrótomo Spencer de secções de $5 \mu \mathrm{m}$, corados por hematoxilina-eosina. O material fixado em Mc Dowell foi incluído em historresina (Historesin; marca Leica); deste material foram obtidos cortes de $2 \mu \mathrm{m}$, corados pela hematoxilina e floxina. As imagens foram obtidas no sistema Q-Win, no microscópio de luz DMR LEICA light microscope. 


\section{RESULTADOS}

De acordo com as técnicas e a metodologia preconizadas pelo projeto, os resultados foram obtidos e descritos conforme os subitens abaixo relacionados:

\subsection{CONFIGURAÇÃO EXTERNA DO FÍGADO}

O fígado de Clarias gariepinus ocupa a cavidade abdominal cranial. Esta região da cavidade abdominal é pequena devido a duas características morfológicas peculiares. A primeira, é que a cabeça desta espécie é comprimida dorso-ventralmente e alongada caudalmente. Os ossos do neurocrânio são espessos e formam um teto alongado para a cavidade orobranquial. Com a presença de uma câmara suprabranquial bem desenvolvida que aloja em seu interior estruturas especiais, os órgãos arborescentes (também chamados suprabranquiais), que, por sua vez, permitem uma respiração aérea acessória, reduz-se ainda mais a dimensão vertical da cavidade (Anexo A). E a segunda deve-se ao fato de a cintura peitoral ser composta por ossos bem reforçados e fundidos entre si. O osso escápulocoracóide une-se ao cleitro, e todo o conjunto une-se com o par contralateral, definindo o limite cranial e o lateral da cavidade abdominal, e comprimindo ainda mais o fígado aí alojado.

Existe uma lobação bem definida para o fígado. Ele está constituído por dois grandes lobos, direito e esquerdo, conectados entre si cranialmente por uma ponte dorsal à transição entre o esôfago e o estômago. O lobo esquerdo apresenta-se ligeiramente maior que o contralateral (Anexo V). Ambos os lobos evidenciam uma separação representada por uma profunda fissura interlobar mediana, ocupada pelo septo sagital, que se apresenta como uma lâmina conjuntiva avascular, unindo o septo transverso ao assoalho da cavidade abdominal. A separação interlobar não é completa, a não ser pela porção de tecido hepático dorsal que 
circunda a transição entre o esôfago e o estômago, já mencionada. Neste ponto, esta transição produz uma acentuada incisura, denominada de incisura esofágica, que determina para ambos os lobos uma extremidade caudal de forma triangular e ápice pontiagudo (Figura 1).

Estes ápices são caracterizados também por um aumento de tecido hepático. Em metade dos espécimes observados, houve a distinção de um processo a partir da margem lateral do ápice, e preferencialmente do lobo esquerdo.

Ambos os ápices continuam tenuemente através de um istmo eminentemente vascular, visto que conspícuas veias se colocam longitudinalmente, circundadas por escasso parênquima hepático. Os ápices ligam-se aos lobos hepáticos acessórios.

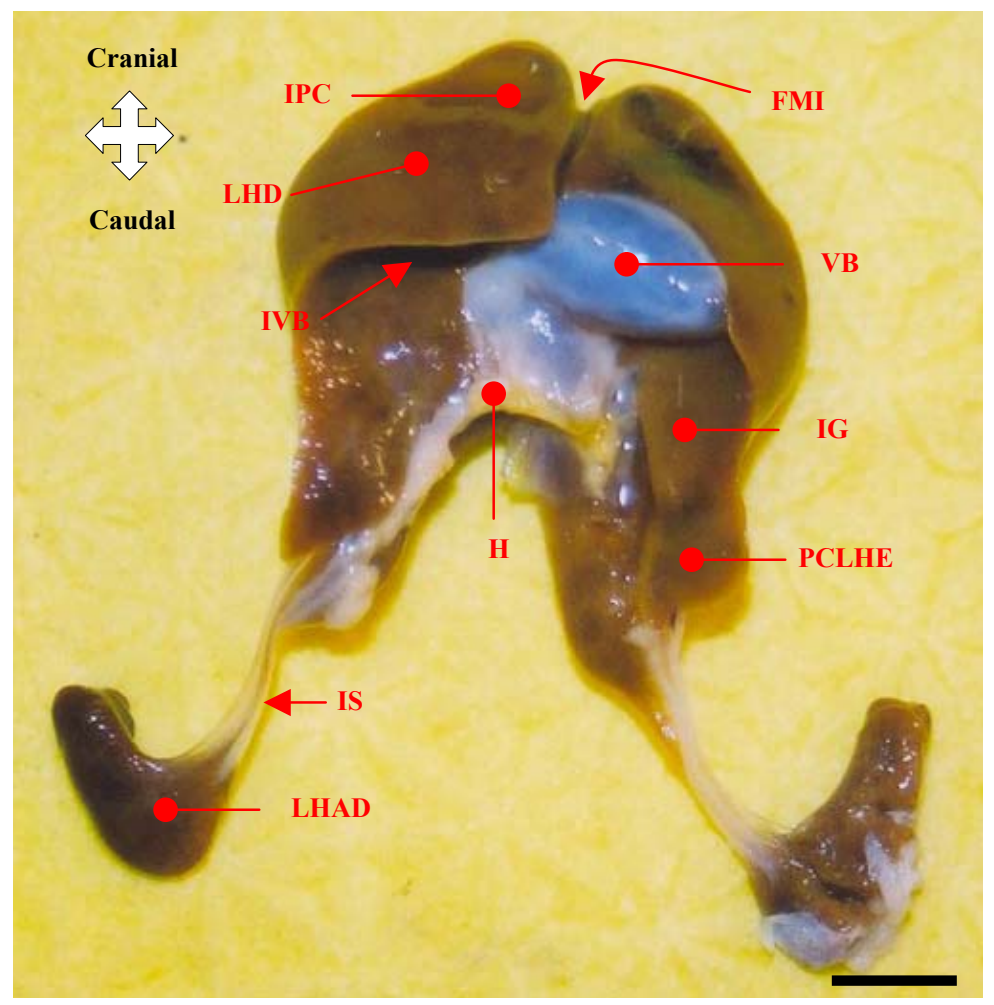

Figura 1- Face ventral do fígado a fresco, mostrando seus elementos descritivos. FMI - fissura mediana interlobar; $\mathrm{H}$ - hilo; IG - impressão gástrica; IPC - impressão do processo coracóide; IS - istmo; IVB - impressão da vesícula biliar; LHAD - lobo hepático acessório direito; LHD - lobo hepático direito; PCLHE - processo caudado do lobo hepático esquerdo (pouco desenvolvido); VB - vesícula biliar (com ápice e corpo deslocados para esquerda). Barra $=14,8 \mathrm{~mm}$ 


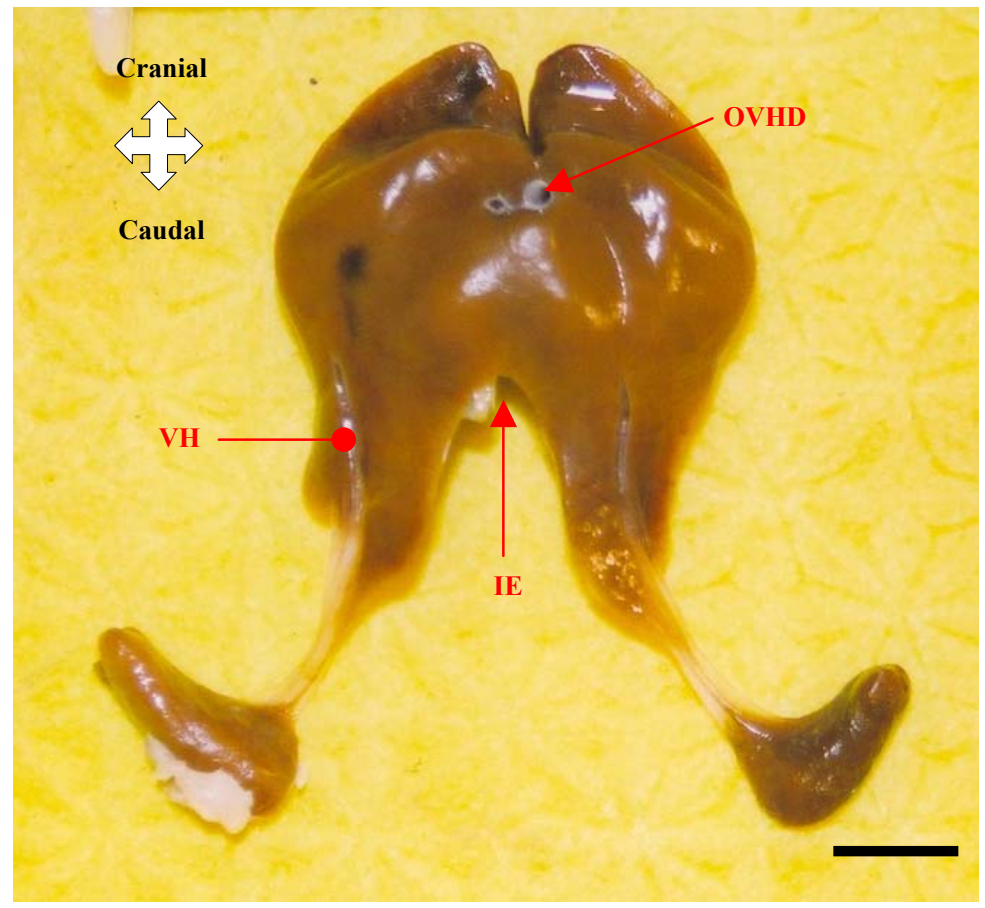

Figura 2- Face dorsal do fígado a fresco, mostrando seus elementos descritivos. IE -incisura esofágica; OVHD - óstio da v. hepática direita; $\mathrm{VH}-\mathrm{v}$. hepática. Barra $=13,5 \mathrm{~mm}$

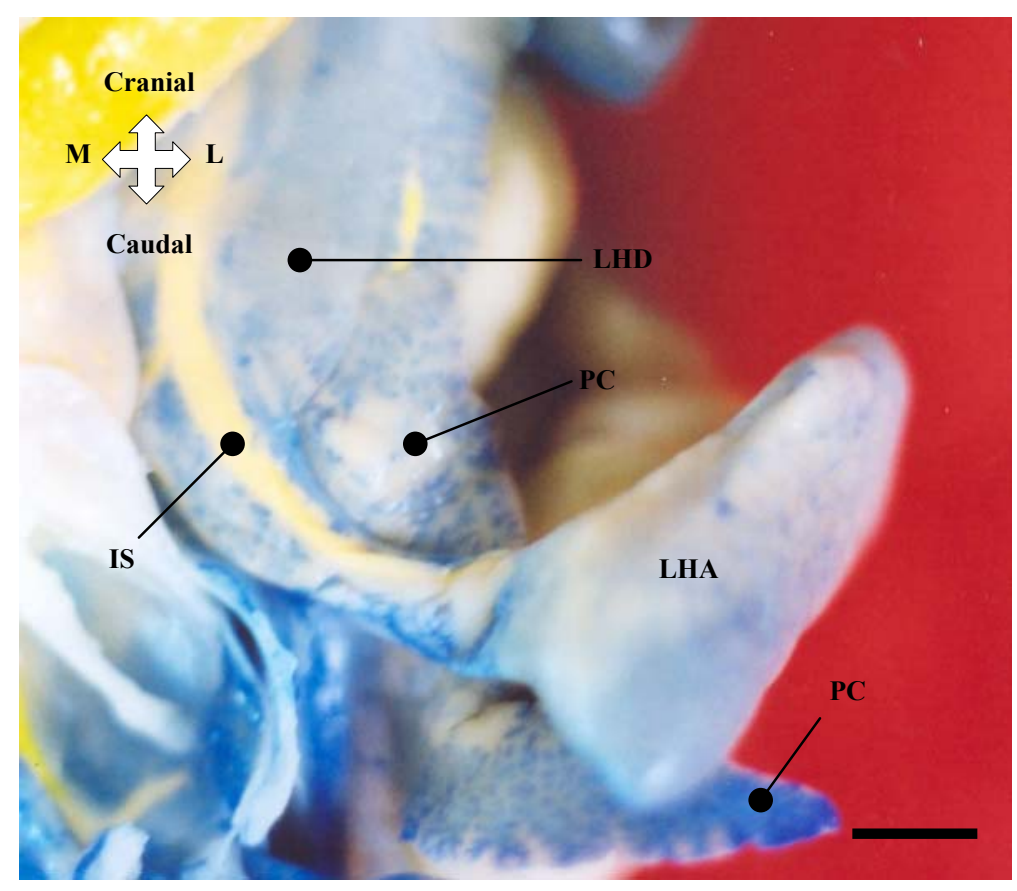

Figura 3- Vista dorsal do lobo hepático acessório (LHA) e do processo caudado (PC) do lobo hepático direito (principal). IS - istmo com a v. hepática injetada. Barra $=20 \mathrm{~mm}$ 
Os lobos hepáticos acessórios (Figuras 2 e 3) direito e esquerdo são bem menores e representam aproximadamente um quinto do tamanho dos lobos principais. Após uma ampla incisão longitudinal na parede abdominal ventral, expondo as vísceras, não há como se observar a presença dos lobos acessórios. Eles estão seqüestrados em um recesso peritoneal lateral à cavidade. Apenas se nota a presença do istmo penetrando em um orifício estreito cranial à primeira costela.

Estes lobos são elipsóides e se relacionam com a musculatura do tronco e com a cute adjacente. Há um pequeno depósito de tecido adiposo, que, uma vez retirado, evidencia o lobo imediatamente caudal ao osso pós-tempôro-supracleitro, bem como um lobo renal, com aspectos topográficos semelhantes.

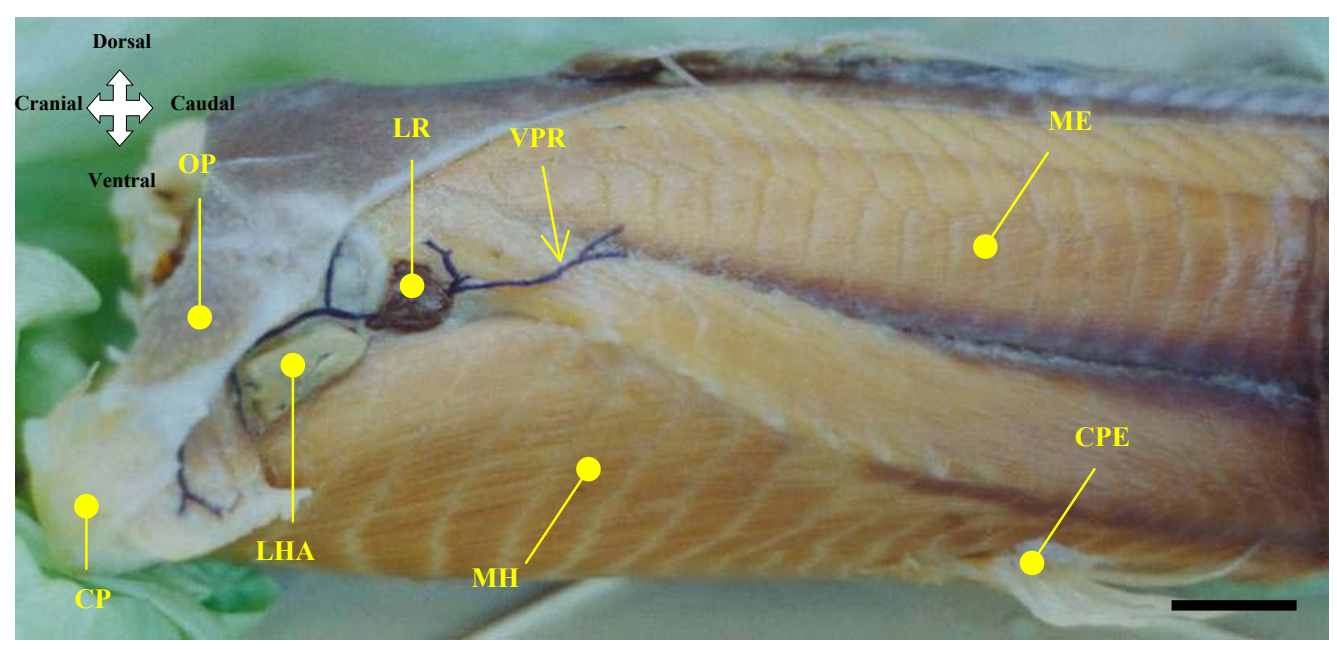

Figura 4- Vista lateral de parte da cabeça e do tronco de Clarias, após dissecação do tegumento para expor os lobos hepáticos acessórios. $\mathrm{CP}$ - cintura peitoral; $\mathrm{CPE}-$ cintura pelvina; LHA - lobo hepático acessório; LR - lobo renal com alguns vasos da circulação porta renal (VPR - Veia porta renal); ME - musculatura epaxial; MH musculatuta hipaxial; OP - osso pós-têmporo-supracleitro. Barra $=7 \mathrm{~mm}$ 


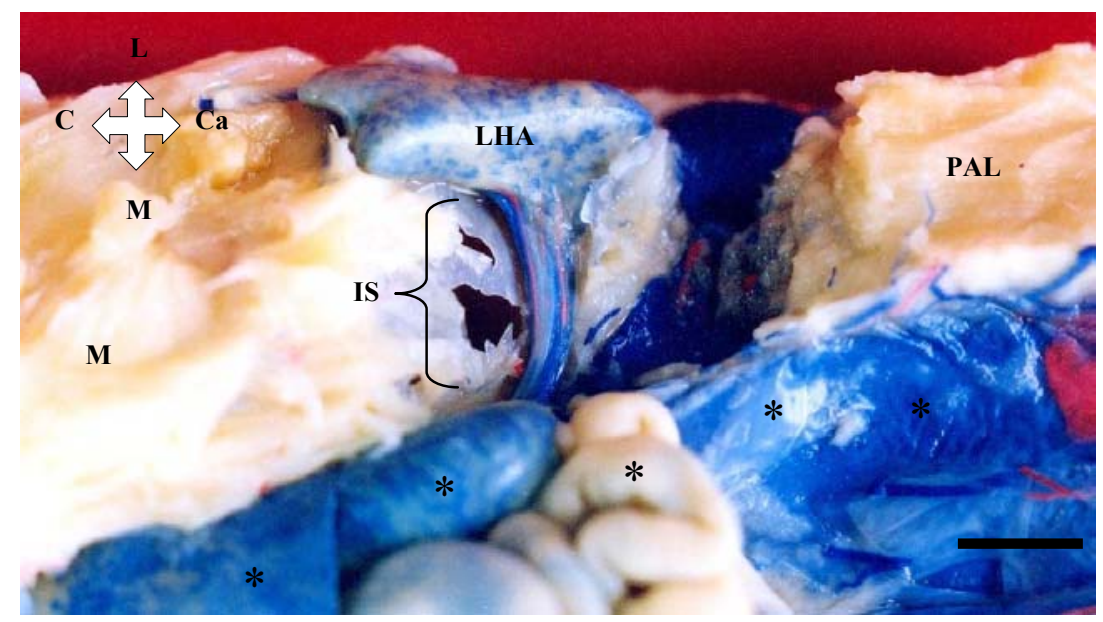

Figura 5- Vista ventral do lobo hepático acessório após ampla dissecação da musculatura adjacente mostrando o istmo, a comunicação com a cavidade peritoneal, e as vísceras abdominais (*). IS - istmo; LHA - lobo hepático acessório; PAL - parede abdominal lateral; M musculatura da cintuta peitoral. Barra $=14 \mathrm{~mm}$

As relações sintópicas dos lobos principais ocorrem entre as faces parietal e visceral e as vísceras circunjacentes. A circulação porta se estabelece na vinculação da drenagem sangüínea destas vísceras e o fígado.

A face visceral é fortemente côncava possuindo a maior área de relação de proximidade com o estômago, onde se nota que o cárdia, a parte pilórica e a curvatura ventricular menor conferem uma profunda impressão gástrica (Fig. 1, IG). Esta impressão é contínua com a impressão da alça proximal do intestino médio, que se estende para o lobo direito. Se a vesícula biliar estiver distendida com conteúdo, compete com um maior contato com o lobo direito, caso contrário, se justapõe entre a alça e o lobo direito com mínima modificação da superfície hepática.

A face parietal é bem maior que a visceral, relacionando-se dorsalmente com o teto da cavidade abdominal até as primeiras vértebras, com o septo transverso, e com os ossos da cintura escapular coracóide. Estes ossos provocam uma profunda impressão horizontal (Fig. 1, IPC).

A face parietal estende-se pela parede abdominal (que é muscular), pelo septo transverso (que é fibroso) e pela parede abdominal dorsal que é óssea. 
Os lobos acessórios não apresentam uma face visceral devido ao relacionamento sintópico com os músculos da parede do tronco e o tegumento, elementos de natureza somática (Figuras 4 e 5).

\subsection{CIRCULAÇÃO PORTA}

O fígado do bagre apresenta dois hilos, um aferente e outro eferente. O hilo aferente é longo (Fig. 1, H), cruzando toda a face ventral em ambos os lobos e formando um sulco raso arqueado com concavidade ventral. As veias portas alojam-se parcialmente neste sulco, podendo ser observada a maior parte de sua extensão. Também suas ramificações mais próximas à superfície são notadas. $\mathrm{O}$ ramo anastomótico é mais profundo, sendo apenas observado nas dissecações, e liga as duas portas mais profundamente. A a. hepática penetra nesse hilo.

O hilo dos lobos acessórios é confinado a um ângulo caudo-medial, e difere em relação aos lobos principais, pois há mais um elemento eferente, a v. hepática. Elas ficam profundamente situadas entre a face visceral e o corpo gástrico (Figura 6). 


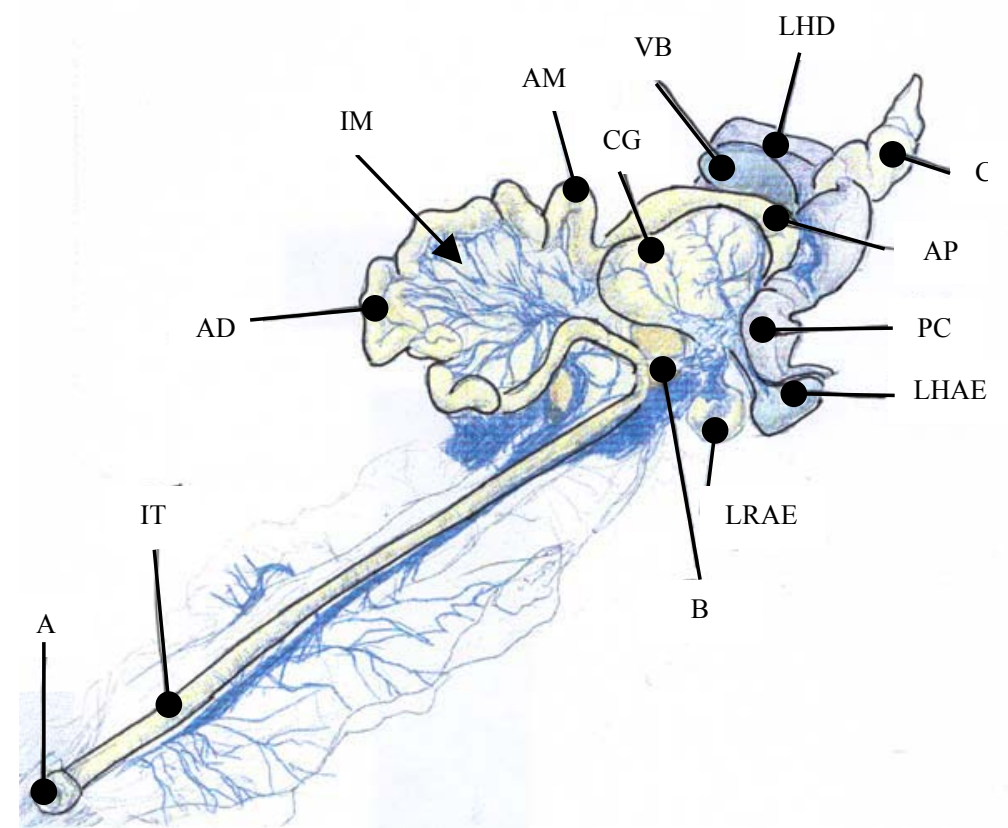

Figura 6- Disposição das vísceras abdominais. A - ânus; AD - alça distal do intestino médio; AP - alça proximal do intestino médio; $\mathrm{B}$ - baço; $\mathrm{C}$ - coração; CG - corpo gástrico; IM Intestino médio; IT - Intestino terminal; LHAE - lobo hepático acessório esquerdo; LHD - lobo hepático direito; VB - vesícula biliar; AM - alça medial do intestino médio; LRAE - lobo renal acessório esquerdo

O sistema porta hepático do bagre africano Clarias gariepinus está representado por duas veias portas principais, direita e esquerda, levemente assimétricas em diâmetro, que drenam o sangue das vísceras correspondentes através de tributários distintos. Ainda, devido a situação peculiar dos lobos acessórios, se definem mais duas veias portas secundárias, ligadas às principais, e designadas igualmente por acessórias, uma esquerda e outra direita. Ambas as vv. portas principais se ramificam atingindo o hilo da face visceral, enquanto que as vv. acessórias, diferentemente, penetram por uma região restrita do lobo. Através de ramos interlobares, ambas as vv. portas principais se anastomosam no parênquima hepático.

A v. porta esquerda, com discreto aumento de diâmetro, se forma pela terminação da v. intestinal, concomitante à desembocadura da v. gastro-intestinal e da v. porta acessória esquerda. A v. porta direita se define pela terminação da v. intestinal cranial, 
simultaneamente à chegada da v. porta acessória ipsilateral, drenando sangue do intestino médio, estômago e vesícula biliar.

Nesta espécie também estão caracterizados dois sítios de comunicação entre o sistema porta hepático e o sistema porta renal através de anastomoses para cada v. porta.

\subsection{PORTA ESQUERDA}

A v. porta esquerda é a continuação da v. intestinal caudal caracterizando uma transição homogênea e retilínea. Este ponto de origem representa também o início do trajeto em pleno lobo hepático. Como todo o hilo correspondente apresenta pouca profundidade e grande extensão, a v. porta fica parcialmente oculta percebendo-se a chegada de mais tributários e a emissão de seus ramos (Figura 7).

\subsubsection{Intestinal Caudal}

O canal alimentar do bagre-africano é curto e facilmente exposto quando examinado após uma incisão da parede abdominal ventral. Após a transição esofágico-gástrica, segue-se um estômago saculiforme dobrado sobre si. A transição para o intestino é notada por um nítido piloro. $\mathrm{O}$ intestino médio segue-se ao estômago por três segmentos bem distintos. $\mathrm{O}$ primeiro, mais proximal, e analogamente correspondente ao duodeno de um mamífero, é o mais curto. Ele é expandido e sugere nas peças observadas, a forma de um cone alongado e encurvado, diminuindo seu diâmetro em direção caudal. Relaciona-se topograficamente com o corpo gástrico, a vesícula biliar e o lobo hepático (Figura 8). Segue-se então a alça média que lembra o jejuno de um mamífero, pelas suas curvaturas e por um mesentério frouxo que lhe garante mobilidade. A alça terminal continua a seguir. Pode apresentar-se um pouco mais 
calibrosa que a média se possuir conteúdo. Ela é facilmente reconhecida pelo seu curso praticamente retilíneo e mediano, entre as gônadas. A inserção no mesentério é feita tanto dorsal como ventralmente, às respectivas paredes abdominais, só que com restrição de mobilidade. A v. intestinal caudal recebe a v. gástrica esquerda que drena grande área do corpo gástrico (Figura 7).

\subsubsection{VV. Esplênicas}

O baço é uma víscera pequena e discoidal. Aplica-se à parede da v. intestinal caudal a tal ponto de ser sustentada por ela. Drena seu sangue através de pequenas vv. esplênicas, podendo ser contadas em número de dez a quinze veias.

\subsubsection{Gástrica Esquerda}

O estômago de Clarias gariepinus apresenta-se com aspecto saculiforme, fortemente dobrado, de tal maneira a aproximar a cárdia e o piloro. O piloro é a porção mais distal da parte pilórica gástrica, e identifica-se por leve constrição.

A v. gástrica esquerda (Figura 7) é o maior vaso que drena o estômago. Atinge grande parte do corpo gástrico. Seu trajeto é em grande parte nítido e isolado, e acompanha a curvatura ventricular maior. Distancia-se da face externa da víscera, dirigindo-se para a v. intestinal caudal. Outros pequenos vasos da parede gástrica podem unir-se a ela, mas são inconstantes. 


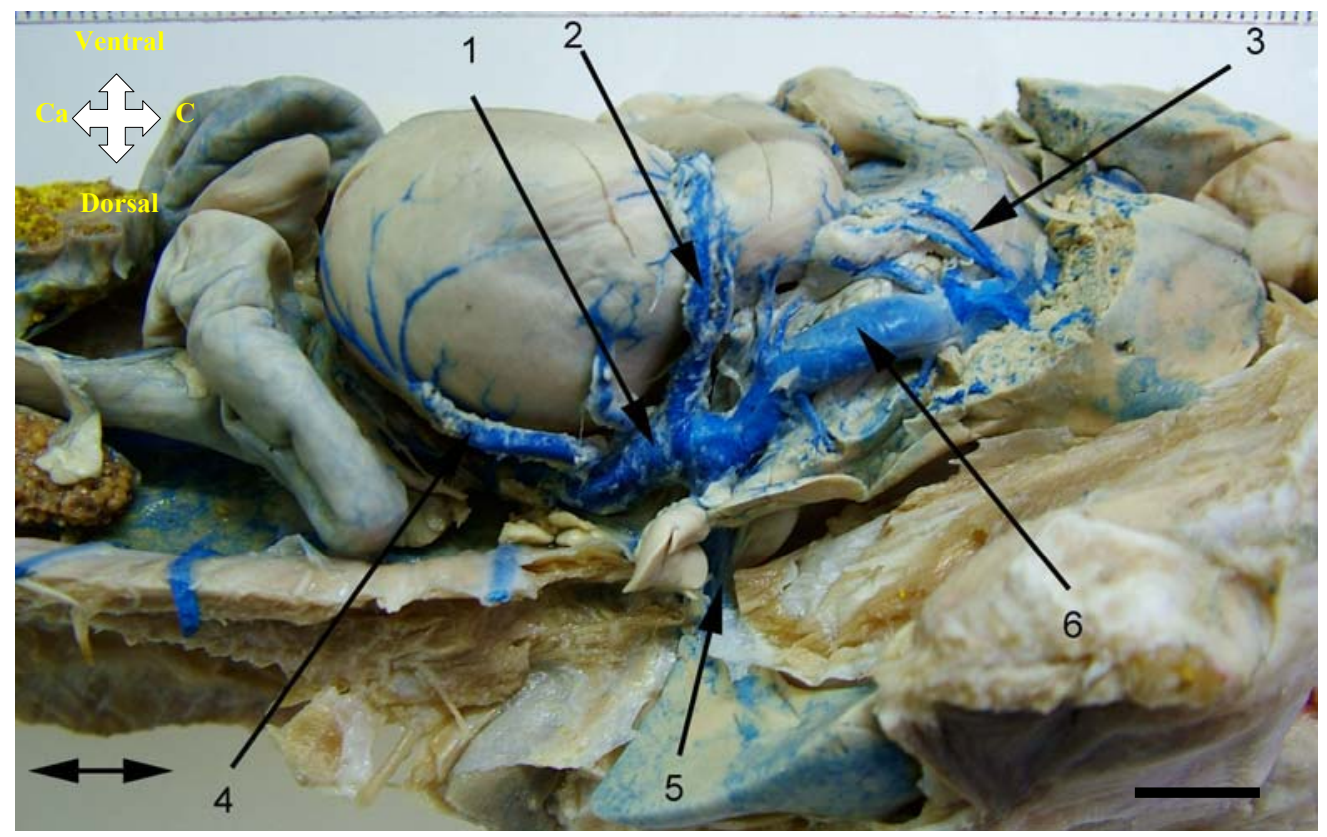

Figura 7- Exposição da v. porta esquerda e seus tributários após dissecção profunda. 1 - v. intestinal caudal; 2 - v. gastro-intestinal; 3 - v. cística; 4 - v. gástrica esquerda; 5 $-\mathrm{v}$. porta acessória esquerda; $6-\mathrm{v}$. porta esquerda. Vista lateral esquerda. Barra $=$ $10 \mathrm{~mm}$

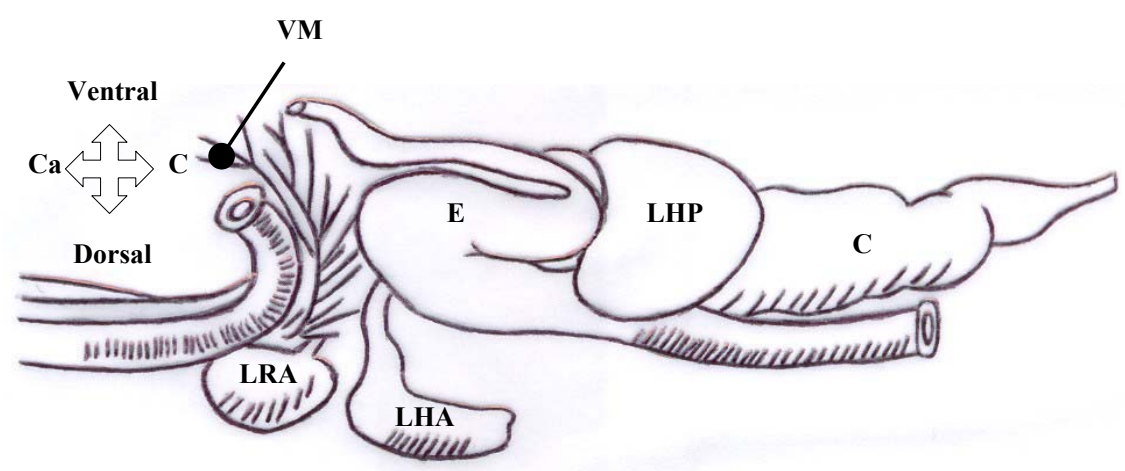

Figura 8- Desenho esquemático mostrando a relação topográfica do estômago e os lobos hepáticos principais. VM- veias mesentéricas; LRA- lobo renal acessório; LHA- lobo hepático acessório; E- estômago; LHPlobo hepático principal; C- coração. Vista lateral esquerda

\subsubsection{Gastro-intestinal}

Esta veia começa a se definir entre a alça proximal e a média. Pequenos ramos da parede intestinal da alça média drenam em toda a sua extensão. Ao se dispor entre a alça proximal e o estômago, permite que pequenos ramos gástricos também desemboquem nela. Com o seu diâmetro aumentado e se dirigindo ao piloro, recebe a v. gástrica direita. Ao 
contornar o piloro, pequenos ramos pilóricos também drenam e finamente desembocam na $\mathrm{v}$. intestinal caudal (Figura 7).

\subsubsection{V. Gástrica Direita}

Ela drena a área circunscrita pela pequena curvatura entre a cárdia e o piloro. Ele é menor e define-se apenas muito próxima a sua desembocadura na v. gastro-intestinal (Figura 9).

\subsubsection{Porta Acessória Esquerda}

A v. porta acessória esquerda origina-se na altura da formação da v. porta principal homolateral. Possui trajeto pelo istmo hepático, sendo facilmente distinta. Ao atingir o pequeno hilo hepático (do lobo acessório) desaparece completamente. Nas peças obtidas por corrosão nota-se a ramificação interna (Figura 9).

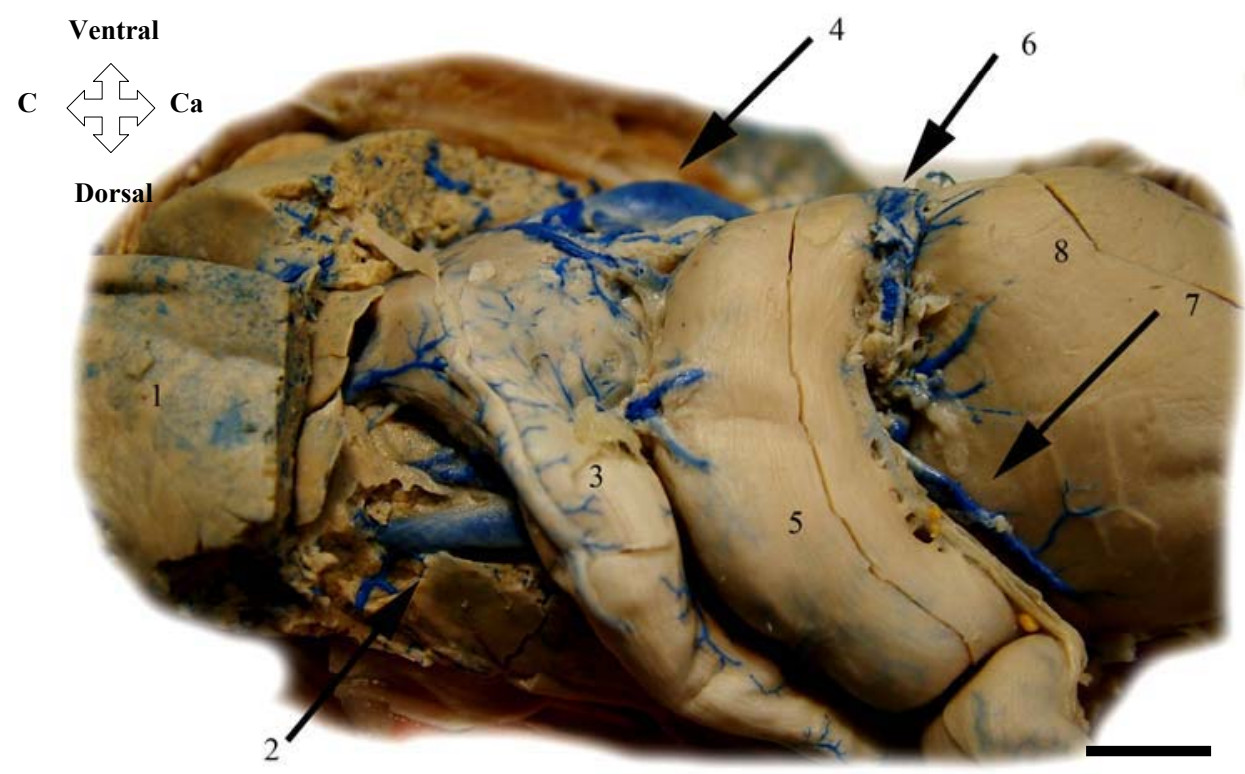

Figura 9- Peça da figura 7 sem o afastamento da vesícula biliar (3) e da alça proximal do intestino (5). 1 - lobo hepático direito; 2 - v. porta direita; $4-v$. porta esquerda; 6 - v. gastro-intestinal; 7 - v. gástrica direita; 8 - corpo gástrcico. Vista ventro-lateral direita. Barra $=10 \mathrm{~mm}$ 


\subsubsection{VV. Císticas}

A vesícula biliar é uma víscera alongada de paredes finas que se dispõem entre o fígado e o estômago. Não há formação de uma veia definida de caráter coletor, mas os pequenos ramos que se formam em sua parede drenam diretamente na v. porta por toda a sua extensão. Como o ápice da vesícula está deslocado para a direita, tem-se a impressão de que tenha relação angiológica com a v. porta direita, mas esta possibilidade não foi observada (Figuras 7 e 12).

\subsubsection{Intestinal Caudal Maior}

A v. intestinal caudal maior é formada pela confluência de duas outras veias que drenam o intestino terminal. Como elas diferem bastante em calibre e topografia, foram consideradas como unidades angiológicas distintas e diferenciadas pelos termos maior e menor (Figura 10).

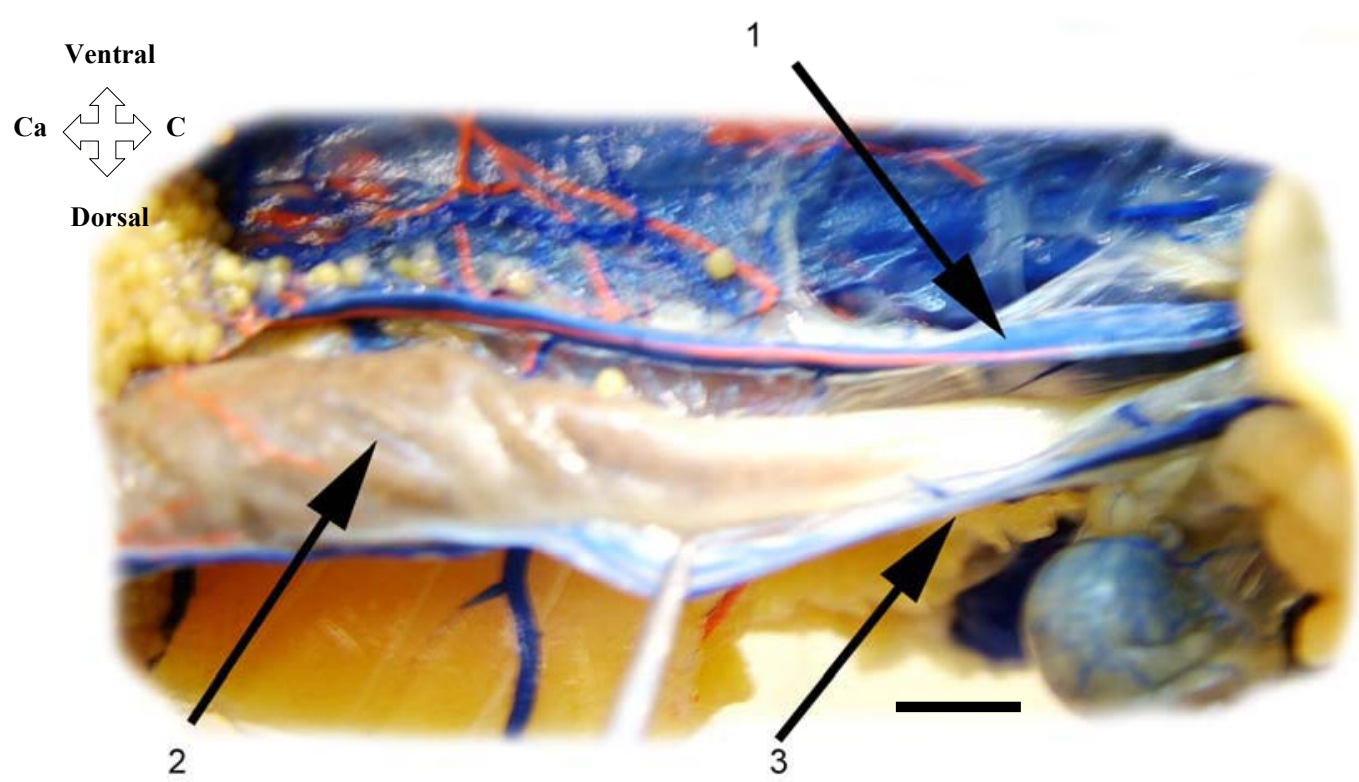

Figura 10-Exposição das veias intestinais caudais, maior (1) e menor (2), unidas à alça terminal (2) pelo mesentério adjacente. Barra $=20 \mathrm{~mm}$ 


\subsubsection{Ramo Anastomótico com a V. Caudal}

O sistema porta hepático se comunica com o sistema porta renal através de um ramo anastomótico que une a v. caudal e a v. intestinal caudal maior. A v. caudal possui seu trajeto totalmente extra-abdominal, e relaciona-se com a coluna vertebral, pois trafega no interior do canal hemal das vértebras. Ao ultrapassar a primeira vértebra caudal, emite o ramo comunicante, como um ramo visceral e intra-abdominal. Ao se aproximar do intestino terminal começa a receber várias pequenas veias de sua parede em pleno mesentério. É um vaso de trajeto retilíneo até a sua terminação (Figura 11).

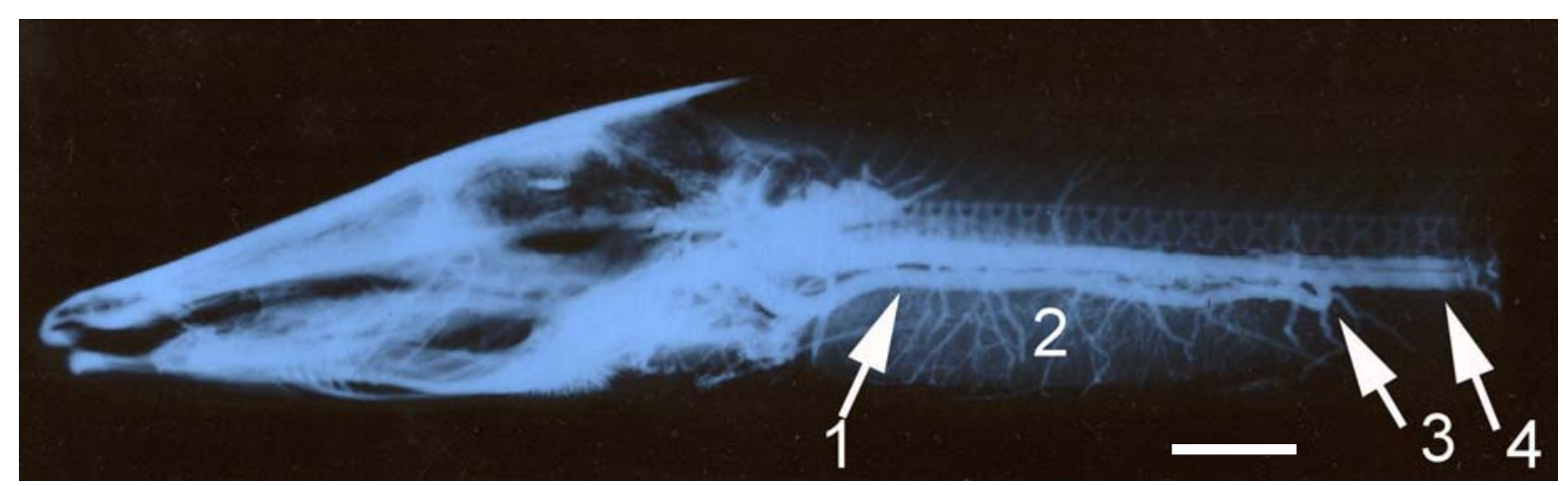

Figura 11- Radiografia látero-lateral com as veias contrastadas. 1 - v. intestinal caudal, 2 - ovário com sua drenagem tanto para o sistema porta renal como para a v. intestinal caudal (veias gonadais), 3 ramo anastomótico da veia intestinal caudal maior com a v.caudal (4). Barra $=6 \mathrm{~mm}$

\subsubsection{VV. Gonadais}

As gônadas representadas pelos espécimes estudados pertencem a fêmeas. Estes ovários são vísceras alongadas e ligam-se ao teto da cavidade abdominal através de meso próprio, o meso-urogenital. As veias que drenam os ovários são visíveis sobre a sua cápsula. Elas ocorrem em grande número e a maioria liga-se ao sistema porta renal, com exceção dos ramos mais caudais, que desembocam na v. intestinal maior (Figura 11). 


\subsubsection{Intestinal Caudal Menor}

Surge a partir de pequenos ramos que drenam a parede intestinal da alça terminal oposta aos ramos que formam a v. intestinal maior. Seu trajeto é retilíneo paralelo ao trajeto da veia caudal maior, e com secção transversal bem menor. Ela fica sustentada por um mesentério que a liga com a parede abdominal ventral (Figura 10).

\subsection{PORTA DIREITA}

A v. porta direita é a continuação da v. intestinal cranial. Este ponto de origem representa também o início do trajeto em pleno lobo hepático direito. Repetindo as características da v. porta contralateral, fica parcialmente oculta percebendo-se a chegada de mais tributários e a emissão de seus ramos (Figura 12).

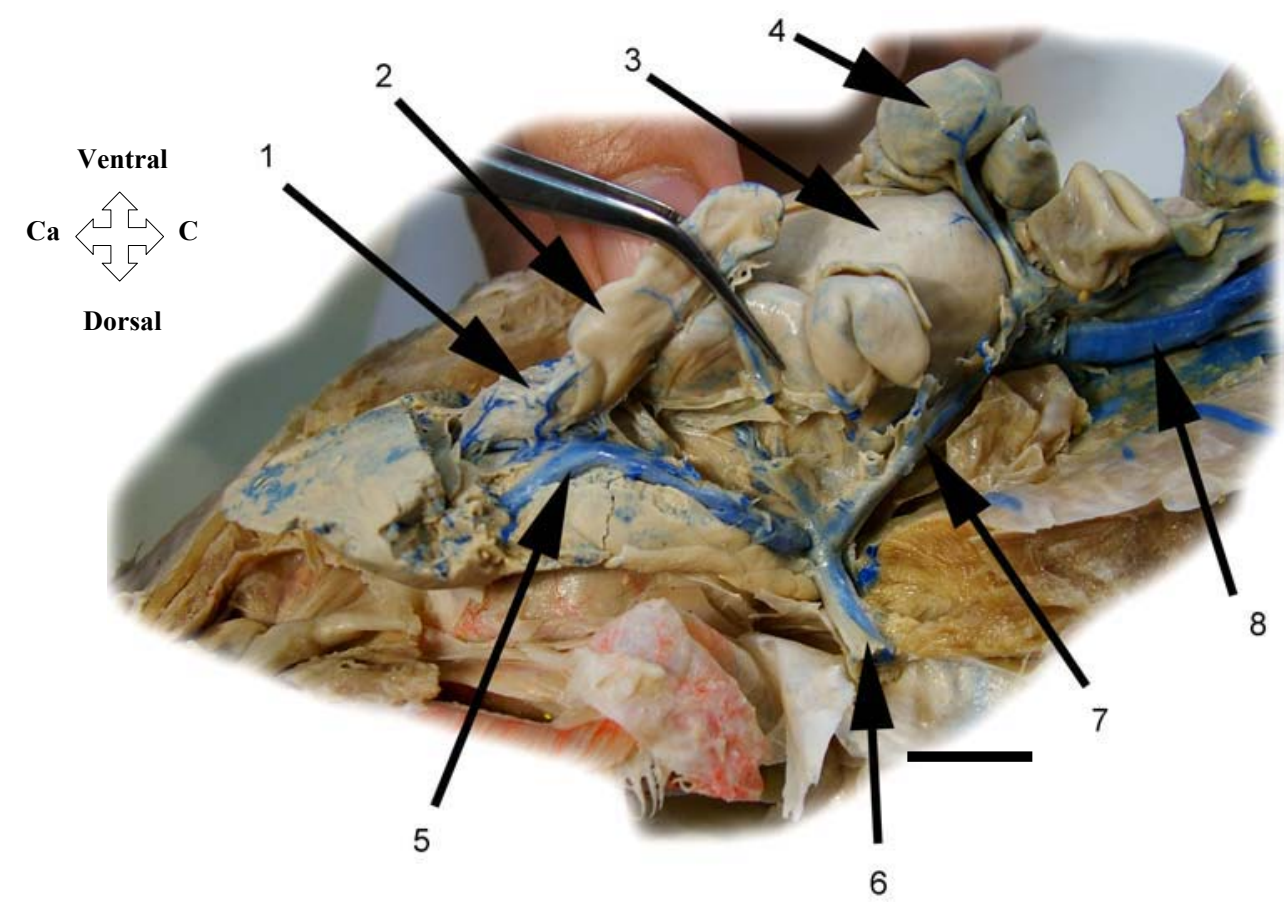

Figura 12- Exposição da v. porta direita e seus tributários após dissecação profunda. 1 vv. císticas; 2 - vesícula biliar; 3 - corpo gástrico; 4 - alça média; 5 - v. porta direita; $6-\mathrm{v}$. porta acessória direita. Vista ventro-lateral direita. Barra $=10$ $\mathrm{mm}$ 


\subsubsection{Intestinal Cranial}

A alça média segue-se à flexura proximal. É o segmento mais sinuoso assemelhandose ao jejuno dos mamíferos, que a faz dirigir-se caudalmente, num pequeno segmento mais dilatado, de aspecto infundibular, mas de paredes normais, sem espessamentos. Neste segmento abre-se o colédoco e o ducto pneumático.

O trecho distal é o mais longo e de diâmetro uniforme. Há uma sucessão de alças suavemente curvilíneas e unidas pela margem livre de um mesentério bem definido e amplo. Estas alças são bastante livres. O mesentério impõe pouca restrição. A veia intestinal cranial é o principal vaso que drena este segmento (Figura 15).

\subsubsection{VV. Mesentéricas}

As vv. mesentéricas (Figuras 13 e 14) surgem a partir de uma malha vascular sobre a parede da alça com 6 a 8 ramos afastados uns dos outros. Caminham de modo convergente na espessura do mesentério até que veias adjacentes se anastomosem para formar um arco vascular bem próximo a v. intestinal cranial. 


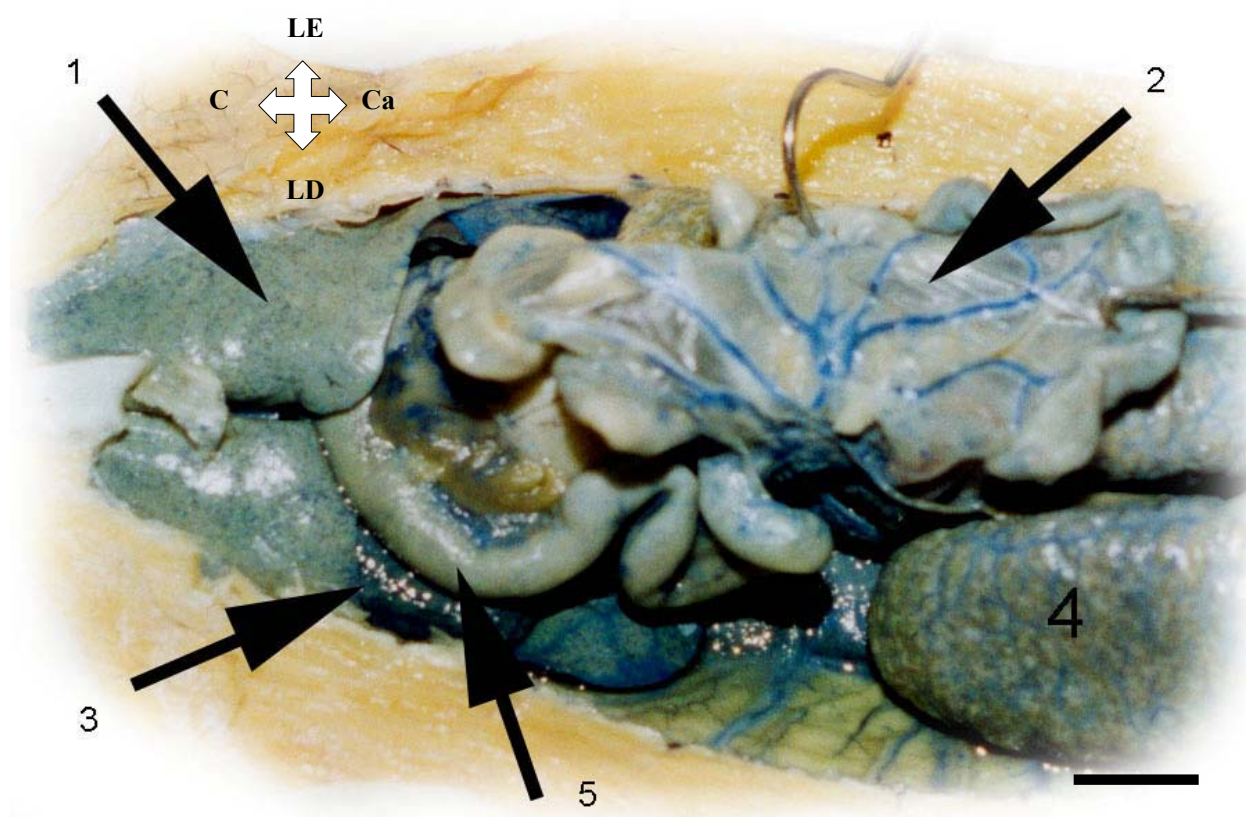

Figura 13- Disposição das vv. mesentéricas com a exposição do mesentério ligado à alça intestinal (5) média. 1 - lobo hepático esquerdo; 2 - vv. mesentéricas; 3 - vesícula biliar; 4 - ovário. Vista ventral. Barra $=10$ $\mathrm{mm}$

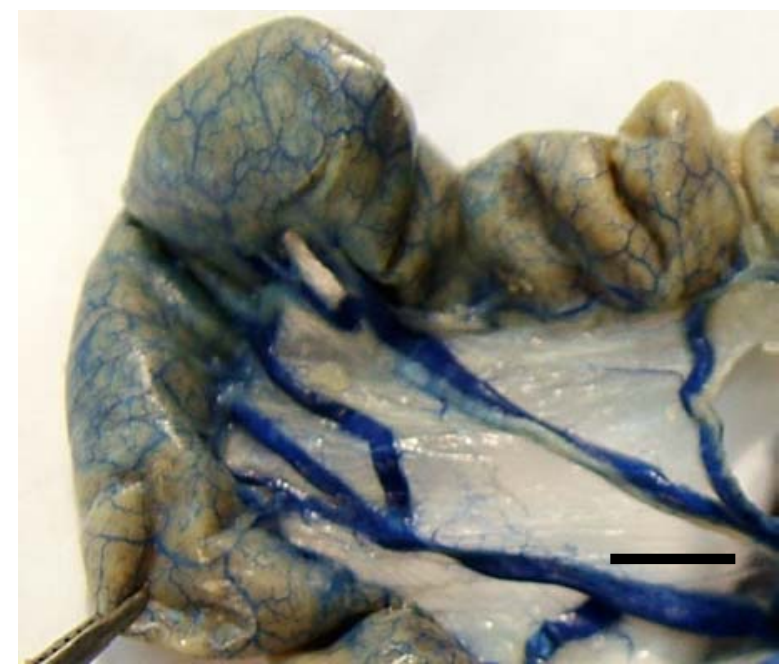

Figura 14- Detalhe da formação das vv. mesentéricas. Barra $=7,5 \mathrm{~mm}$ 


\subsubsection{Porta Acessória Direita}

Apresenta similaridade com a homóloga esquerda, sendo praticamente simétrica na origem e no trajeto. Esta veia origina-se igualmente na altura da formação da v. porta principal homolateral apresentando as mesmas características do lobo acessório oposto.

\subsubsection{Ramo Anastomótico com a Veia Porta Renal Direita}

O sistema porta renal possui uma segunda anastomose com o sistema porta hepático. A primeira é mantida com as porções mais caudais do abdome (item 4.3.6.1) e o vaso para esta finalidade é calibroso, distinto, e pertence aos tributários da v. porta esquerda. Este ramo anastomótico ostenta características opostas, ou seja, situa-se no abdome cranial próximo ao fígado, possui calibre reduzido e drena como tributário da v. porta direita (Figura 15).

\subsubsection{V. Segmental 1}

Os vasos segmentais representam as artérias e as veias de caráter metamérico e, numericamente, relacionados às vértebras. São virtualmente homólogos aos vasos intercostais e lombares dos mamíferos, mas diferem filogeneticamente destes, pois pertencem ao sistema porta renal. A v. segmental 1 é, portanto, o primeiro destes vasos, que mantém uma característica de exceção por comunicar-se com o porta hepático. A drenagem, propriamente dita, também varia, podendo ora ocorrer diretamente na v. porta acessória (4.4.2), ora no ramo comunicante (4.4.2.1) (Figura 15). 


\subsection{RAMIFICAÇÃO DAS VV. PORTAS}

As duas veias porta principais drenam o sangue das vísceras abdominais através de uma rica rede de vasos tributários que se relacionam com estes órgãos (Anexo AA). O calibre destes ramos diminui progressivamente, reduzindo-se até não serem mais observados a olho desarmado. Antes disso, há a emissão de vasos menores, que saem do ramo de maneira arboriforme e também sem apresentar anostomoses perceptíveis, sugerindo uma disposição em segmentos funcionais. É impossível contar estes ramúsculos, mas os moldes de vinilite revelam que os ramos distribuem-se em número de 7 a 8 para o lobo esquerdo e de 4 a 5 para o lobo direito (Figura 15).

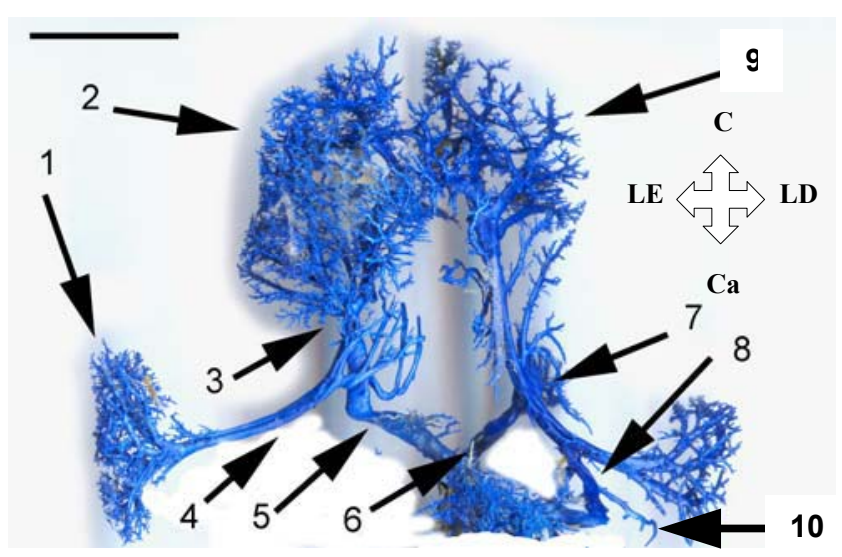

Figura 15- Ramificação das veias porta direita e esquerda obtida por injeção de vinilite e corrosão total. 1 - Ramos da v. porta acessória esquerda, 2 ramos da v. porta esquerda, 3, 7 - ponto de confluência das veias formadoras de ambas as veias portas, $4-\mathrm{v}$. porta acessória esquerda, 5 v. intestinal caudal, $6-\mathrm{v}$. intestinal cranial, 8 ramo anastomótico com a v. porta renal direita, 9- ramos da v. porta direita, 10- veias segmentais. Vista dorsal. Barra $=15 \mathrm{~mm}$ 


\subsection{HEPÁTICAS}

As v. hepáticas drenam o sangue do fígado diretamente para o seio venoso. Há a formação de duas veias, uma direita e outra esquerda, que são visíveis devido ao seu trajeto superficial pela face dorsal do figado. Cada uma delas consegue servir tanto os lobos principais como os acessórios dando um aspecto uniforme na circulação. Conforme descrição anterior, há ainda uma relação direta com a discreta assimetria dos lobos hepáticos, refletindo no óstio da v. hepática esquerda que é maior que o direito (Figura 16).

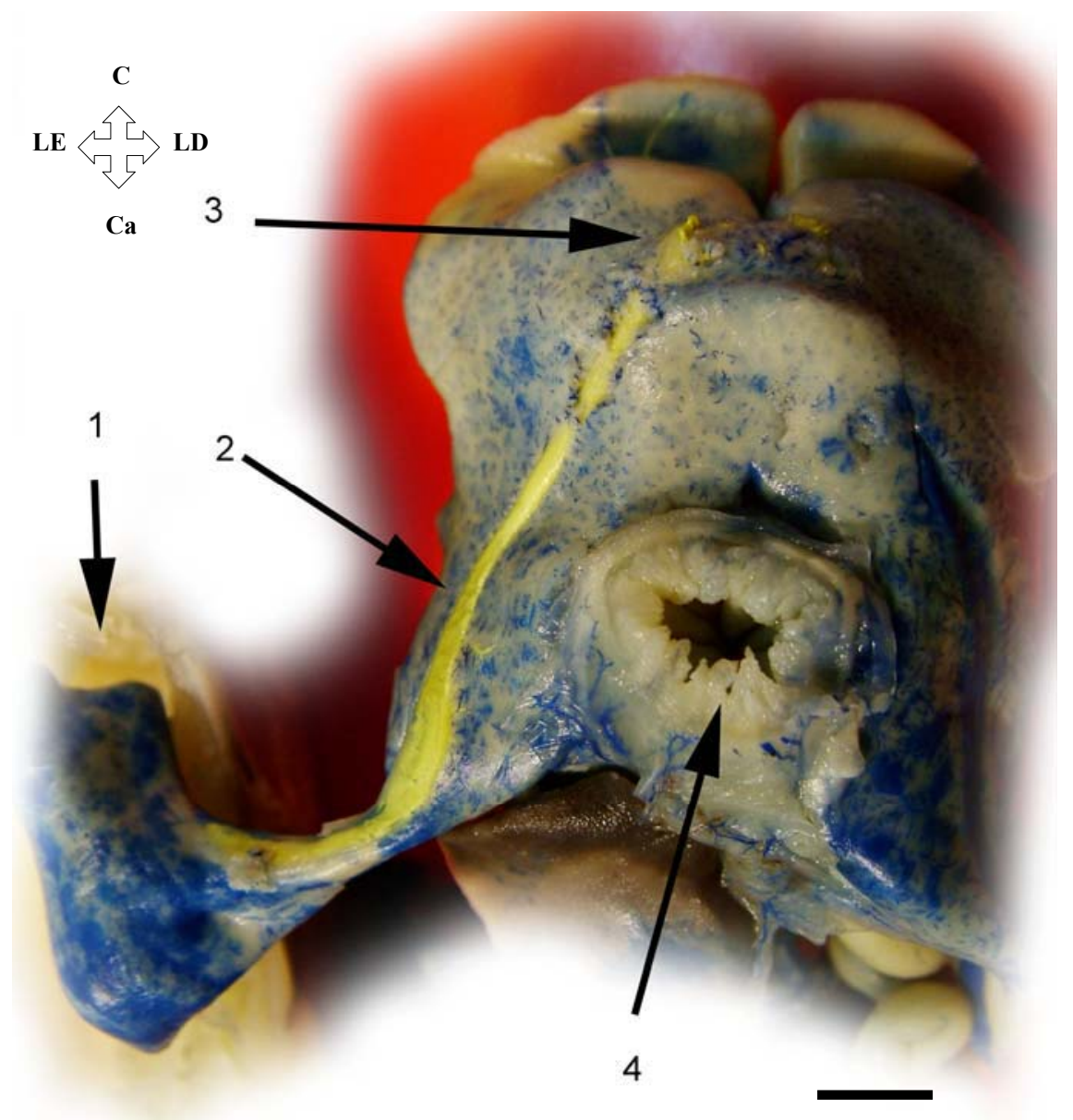

Figura 16- Vista dorsal ilustrando a disposição da v. hepática esquerda. 1 Lobo acessório, 2 - v. hepática, 3 - óstio da v. hepática, 4 esôfago. Barra $=16 \mathrm{~mm}$ 


\subsection{HISTOLOGIA DO FÍGADO DE Clarias gariepinus}

O istmo que liga o corpo principal do fígado aos lóbulos acessórios é composto por tecido hepático, tecido pancreático e ramos da veia porta, ramos da artéria hepática, ramos da via hepática e ductos biliares (Figura 17).

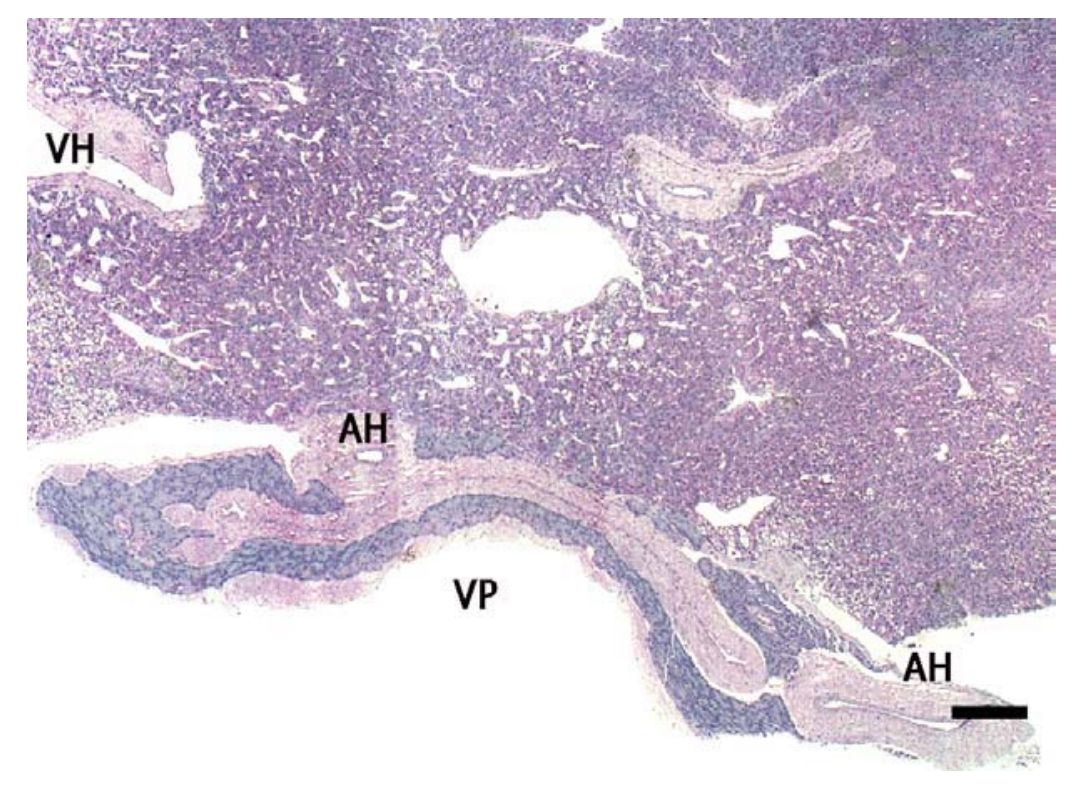

Figura 17- Secção transversal do istmo hepático, mostrando os ramos das veias portas (VP), circundadas por tecido pancreático e os ramos das artérias hepáticas (AH). No canto superior direito, observa-se um ramo da veia hepática $(\mathrm{VH})$ Historresina, hematoxilina-floxina.Barra $=120$ micrômetros

Os ramos da veia porta estão associados ao tecido pancreático (Figura 18), que os envolve. Os ramos da artéria hepática podem assumir duas posições: ao lado da veia porta, no mesmo plexo (Figura 17) ou pode formar um plexo isolado (Figura18). 


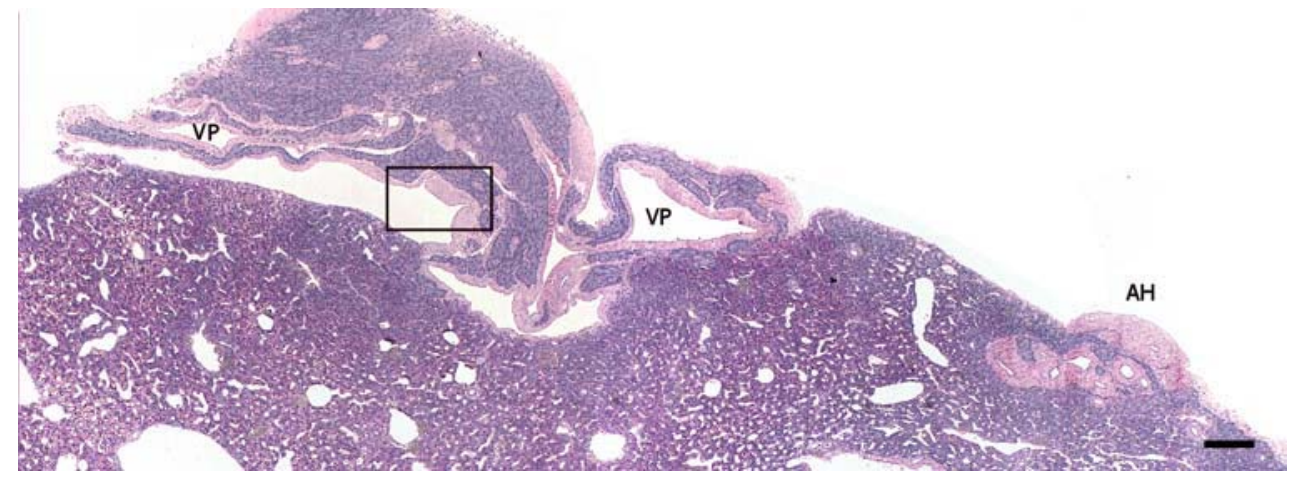

Figura 18- Secção transversal do istmo hepático, mostrando os ramos das veias portas (VP), circundadas por tecido pancreático e os ramos das artérias hepáticas (AH). O quadro mostra a área onde foi obtida a figura 17. Historresina, hematoxilina-floxina. Barra $=120$ micrômetros

O tecido pancreático e as veias portas formam um cordão que corre na superfície do istmo; este cordão é circundado externamente por uma camada de tecido conjuntivo pancreático e musculatura lisa disposta longitudinalmente. $\mathrm{O}$ conjunto é revestido por um mesotélio apoiado em uma fina camada de tecido conjuntivo frouxo (Figura 19).

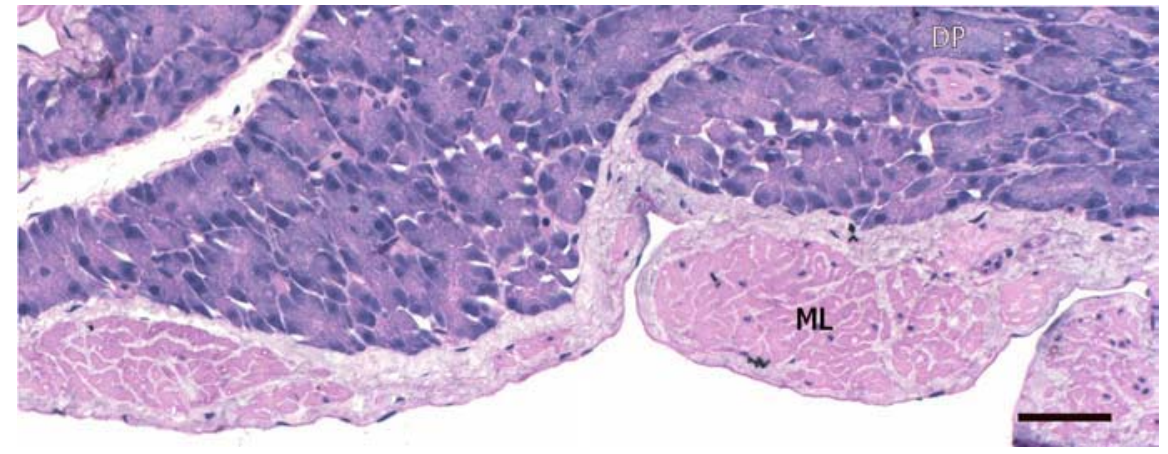

Figura 19- Ampliação da área delineada na Figura 18, onde podem ser observados os feixes longitudinais de músculo liso (ML). Alguns ductos pancreáticos (DP) podem ser observados no tecido pacreático. Historresina, hematoxilina-floxina. Barra $=60$ micrômetros

Os ductos biliares formam um cordão com um grupo de vasos circundados por tecido conjuntivo denso em uma das extremidades do istmo, mas também são encontrados no interior do tecido hepático. No cordão do istmo, são revestidos por epitélio cúbico simples baixo (Figura 20). 


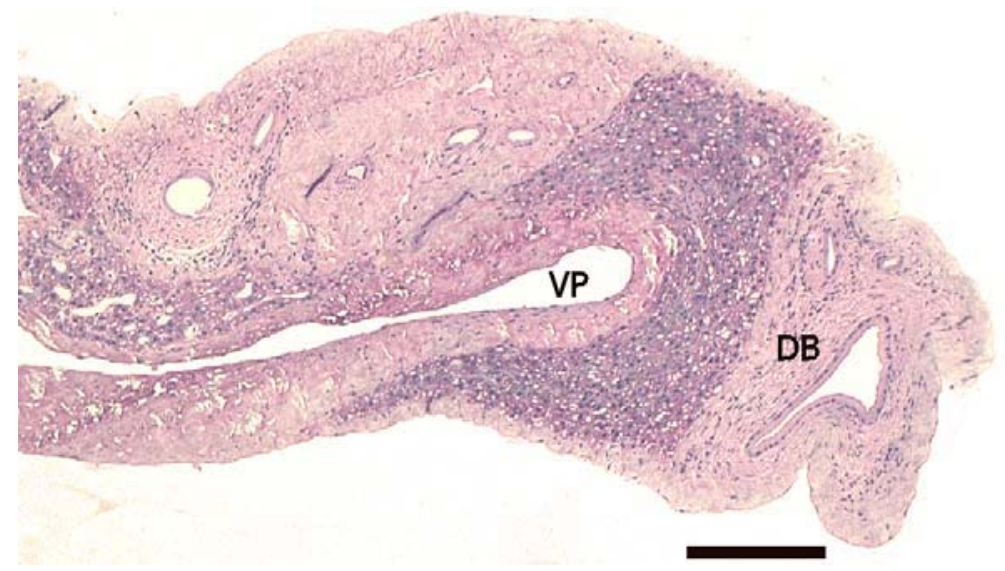

Figura 20-Secção transfersal do istmo, mostrando parte da veia porta, circundada por tecido hepático e um conjunto de ductos biliares de vários tamanhos revestidos por epitélio cúbico simples e circundados por tecido conjuntivo denso. Historresina, hematoxilina-floxina. Barra $=120$ micrômetros

A veia hepática forma um único vaso de luz ampla com uma espessa parede de tecido conjuntivo na face voltada para a cavidade abdominal e uma parede delgada na face voltada para o tecido hepático (Figura 21).
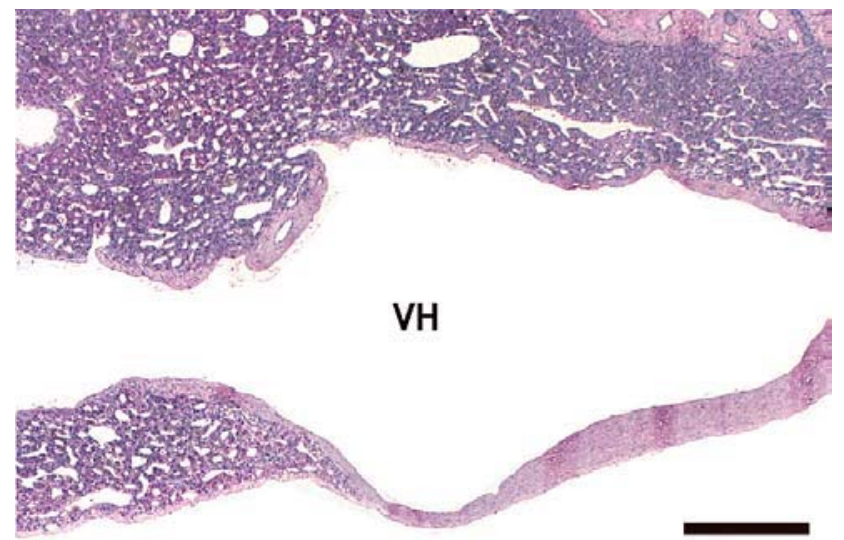

Figura 21- Corte tranversal do istmo hepático, mostrando o ramo da veia hepática (VH). Historresina, hematoxilina-floxina. Barra $=120$ micrômetros

Seguindo-se a face interna da veia hepática, é possível observar, com freqüência, a afluência de vasos sinusóides no interior da veia (Figura 22), que caracterizam este vaso como a veia hepática. 


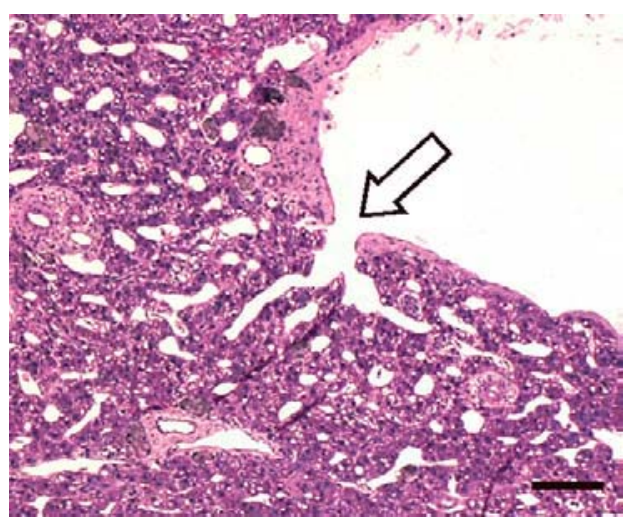

Figura 22- Em algumas áreas da parede da veia hepática observa-se a abertura de vasos sinusóides no interior da veia hepática (seta). Historresina, hematoxilinafloxina. Barra - 60 micrômetros

O lóbulo intramural é formado por cordões de hepatócitos que circunda os vasos sinusóides dilatados. Uma característica peculiar deste lóbulo é a presença de melanomacrófagos de grande tamanho (Figura 23).

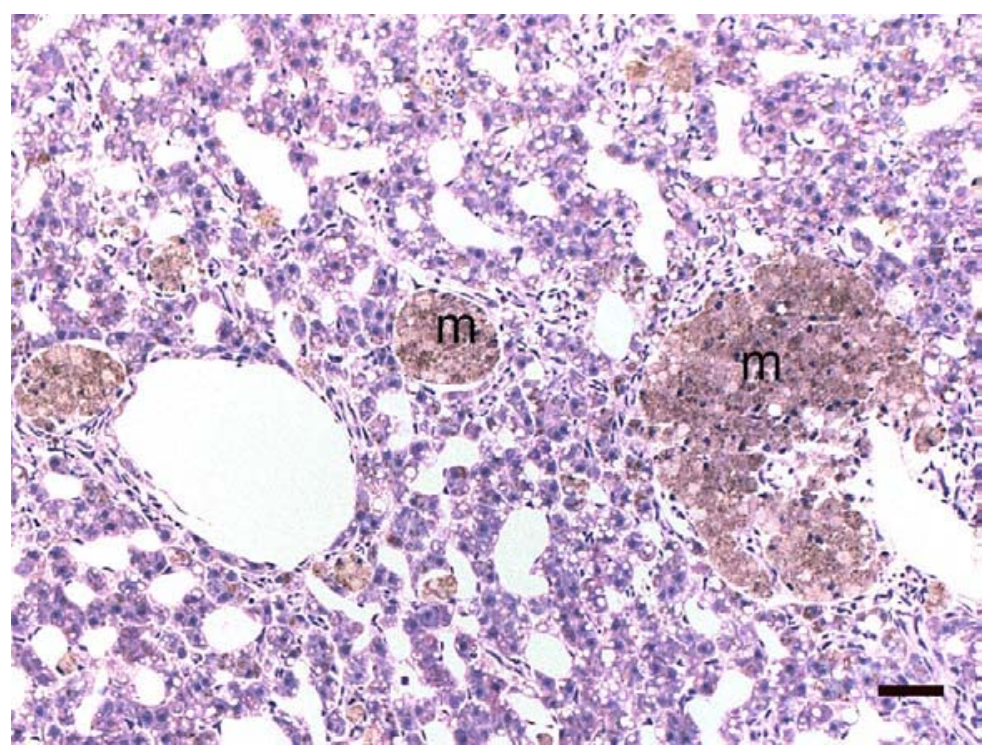

Figura 23- Aspecto histológico do lóbulo hepático intramural. Observar a presença de melanomacrófagos. Historresina, hematoxilina-floxina. Barra $=30$ micrômetros 


\section{DISCUSSÃO}

Apesar de dispormos de uma vasta literatura acerca das atividades aquícolas, em especial as que se relacionam aos aspectos da biologia e cultivo de peixes de água salgada e doce, algumas espécies carecem de estudos mais acurados, principalmente relacionados às variações anátomo-funcionais que são constantemente observadas em exemplares de uma mesma espécie. Entre diferentes espécies de um mesmo gênero estes estudos são ainda mais raros, e dentre as variações mais comuns estão àquelas relacionadas às particularidades do sistema circulatório, apesar de apresentar, muitas vezes, características muito primitivas e bastante simplificadas nos peixes.

A partir dos levantamentos bibliográficos e dos resultados obtidos através da metodologia utilizada neste trabalho, foi possível detectar diversas peculiaridades referentes à morfologia e topografia do fígado de Clarias gariepinus, bem como do sistema porta hepático desta espécie, relacionando esses resultados com os apontamentos feitos em diversos trabalhos, dentre eles, os de Romer e Parsons (1985) e de Roux (1922), que tratam, em especial, do espaço ocupado pelo fígado dos peixes na cavidade abdominal e suas relações topográficas com os órgãos circunvizinhos; os de Hildebrand (1995), que aborda a lobação do fígado em vertebrados, e ainda com os relatos de Amlacher (1954), que se refere à irregularidade no formato do fígado da carpa (Cyprinus carpio), fato também observado no fígado de Clarias gariepinus.

No que diz respeito à composição histológica do fígado, os resultados foram comparados aos descritos por Harder (1975), que relata as características observadas no fígado da carpa (Cyprinus carpio), por Hampton et al. (1988) e Hampton, Lantz e Hinton (1989), que comentam sobre os grupos celulares que se reúnem para formar o fígado dos peixes, por Bunton (1993) e Okihiro e Hinton (2000), que pormenorizam a origem dos 
hepatócitos e das células de ductos biliares, e ainda por Santos (2003), que se refere, particularmente, à histologia do fígado de Clarias gariepinus.

Com relação à circulação sangüínea em peixes os resultados descritos em capítulo precedente foram confrontados com as considerações feitas por Orr (1986), que aborda as características gerais do sistema circulatório em peixes, e com os apontamentos de Bond (1996), que cita a posição geralmente ocupada pelo coração destes animais.

Concernente ao foco deste trabalho, ou seja, ao estudo do sistema porta hepático, os resultados foram comparados às ponderações de Harder (1975), que trata das características gerais deste sistema utilizando a carpa (Cyprinus carpio) como modelo biológico, e de Allen (1905), que estudou o sistema porta hepático em Ophiodon elongatus. Já, em relação ao sistema porta hepático de Clarias gariepinus, apesar de todo esforço para identificação de trabalhos que tratassem desse assunto, foram encontrados apenas os apontamentos de Nawar (1955), que concentrou seus esforços na circulação sangüínea de Clarias lazera (sinonímia de Clarias gariepinus, segundo Teugels, 1986).

No que tange ao espaço ocupado pelo fígado dos peixes, nossos apontamentos indicam que o fígado de Clarias gariepinus ocupa a cavidade abdominal cranial posicionando-se bastante próximo à cintura peitoral a qual, por ser composta por ossos bem reforçados e fundidos entre si, isto é, pelo osso escápulo-coracóide que se une ao cleitro, e por todo o conjunto que fica unido ao par contralateral, define o limite cranial e o lateral da cavidade abdominal, comprimindo ainda mais o fígado aí alojado. Essa cintura peitoral assemelha-se em função ao septo transversal, pois ambos separam a cavidade abdominal da cavidade pericárdica, e, de acordo com a citação de Romer e Parsons (1985), o septo transversal separa a cavidade pericárdica do celoma remanescente, estando presente nos vertebrados inferiores. Ainda com respeito ao mesmo assunto, observou-se nos exemplares estudados que o fígado de Clarias gariepinus está circundado por diversos órgãos viscerais, 
dentre eles o estômago, a vesícula biliar, o baço e o intestino; além disso, verificou-se que este órgão sofre alterações morfológicas. Esse mesmo aspecto, em parte, já havia sido observado por Roux (1922) ao descrever o fígado da carpa (Cyprinus carpio) e citar que a forma desse órgão é extremamente variável em peixes, assim como em outros animais, não somente interespecificamente, mas também em diferentes indivíduos de uma mesma espécie, afirmando ainda que ele costuma ocupar o espaço intracavitário entre a parede do corpo, o intestino, o baço, a vesícula biliar e o pâncreas, formando um molde do espaço que ocupa, e acrescentando ainda que a forma do fígado, especialmente em peixes, parece ser, pelo menos parcialmente, determinada pelos órgãos que o cercam. Romer e Parsons (1985), partidários da mesma opinião, ressaltam o fato de o fígado geralmente acomodar-se entre os órgãos da parte anterior da cavidade do corpo.

No tocante aos lobos do fígado, verificou-se que, em Clarias gariepinus, a lobação é bem definida neste órgão, sendo constituído por dois grandes lobos, direito e esquerdo, conectados entre si cranialmente por uma ponte dorsal à transição entre o esôfago e o estômago, sendo que o lobo esquerdo costuma se apresentar ligeiramente maior que o direito. Observou-se ainda que esses lobos apresentam uma extremidade caudal de forma triangular e ápice pontiagudo, que continua tenuemente através de um istmo eminentemente vascular, visto que, conspícuas veias se colocam longitudinalmente, circundadas por escasso parênquima hepático, e esses ápices ligam-se aos lobos hepáticos acessórios direito e esquerdo, que são bem menores e representam cerca de um quinto do tamanho dos lobos principais, ficando seqüestrados em um recesso peritoneal lateral à cavidade, notando-se apenas a presença do istmo que penetra em um orifício estreito, logo cranial à primeira costela.

Ao ser definida, com certa clareza, a lobação do fígado de Clarias gariepinus, confirmou-se, ao menos em parte, os comentários de Hildebrand (1995), a partir de seu relato 
de que o fígado dos vertebrados tende a ser lobulado e, freqüentemente, apresentar dois lobos principais; esses lobos podem estar um ao lado do outro (como em Clarias gariepinus), ou um em frente ao outro, e o órgão pode não ser lobulado ou apresentar muitos arranjos, numa variedade de padrões que não têm funcionalidade conhecida ou significado sistemático. Essa última afirmação poderia justificar o caráter observado no fígado de Clarias gariepinus que apresenta mais dois lobos acessórios (direito e esquerdo) sem uma função aparentemente definida.

A irregularidade na forma do fígado de peixes, por sua vez, já havia sido observada por Amlacher (1954) ao estudar o fígado da carpa (Cyprinus carpio) e verificar que o mesmo apresenta, em posição caudal aos dois lobos principais esquerdo e direito, mais dois lobos adicionais, chamados de lobos menores, o lobo ventrolateral e o lobo caudal. Ele cita ainda que, do lobo principal esquerdo do fígado da carpa, geralmente se formam duas outras porções, designadas pelo autor como lobos secundários, quase sempre desligadas do resto do órgão pelas alças intestinais, cujo curso não é muito bem definido. Apesar de não se tratarem dos mesmos lobos acessórios encontrados em Clarias gariepinus, fica evidente que a irregularidade na forma do fígado de peixes é uma característica marcante, porém não exclusiva do bagre africano.

No atinente à composição histológica do fígado de Clarias gariepinus, o trabalho revela que neste peixe, de fato, os lobos principais estão ligados aos lobos acessórios através de dois istmos que, por sua vez, são formados por tecido hepático, tecido pancreático e por ramos das veias porta acessórias, das artérias hepáticas acessórias, das veias hepáticas e dos ductos biliares. O trabalho revela ainda que os ductos biliares formam um cordão com um grupo de vasos circundados por tecido conjuntivo denso em uma das extremidades do istmo, mas também são encontrados no interior do tecido hepático. Supõe-se que a relação entre os ductos biliares e o tecido hepático poderia ser explicada através das justificativas apontadas 
por Bunton (1993) e Okihiro e Hinton (2000) ao afirmarem que, em peixes, os hepatócitos formam túbulos associados a células biliares. Entre os ductos biliares e os túbulos de hepatócitos existem canais intermediários que são denominados pré-dúctulos biliares. As células que os compõem são chamadas células epiteliais pré-ductulares biliares ou CEPDBs, comparáveis aos canais de Hering, mas que se situam no interior dos túbulos dos hepatócitos. Acredita-se que as CEPDBs sejam as células-fontes de hepatócitos e de células de ductos biliares em fígado de peixes e sejam equivalentes às células ovais de mamíferos, sendo facilmente diferenciadas das outras células do parênquima por expressarem citoqueratinas AE1/AE3.

Com respeito à veia hepática de Clarias gariepinus, o trabalho revela que ela parece formar um único vaso de luz ampla com uma espessa parede de tecido conjuntivo na face voltada para a cavidade abdominal e uma parede delgada na face voltada para o tecido hepático, revelando que o fígado se abre de maneira continua através de vários óstios drenando diretamente do tecido para a veia hepática. Seguindo-se a face interna da veia hepática, é possível observar, com freqüência, a afluência de vasos sinusóides no interior da veia. Apesar da ocorrência de mais duas veias porta em Clarias gariepinus que estão ligadas aos lobos acessórios esquerdo e direito, a vascularização nestes lobos relacionada à origem das veias hepáticas parece não fugir aos padrões observados por Harder (1975) ao afirmar que na carpa (Cypriunus carpio), os capilares sangüíneos, derivados das veias porta, fundem-se simultaneamente para dar origem aos vasos sangüíneos maiores, que finalmente formam a veia hepática.

A histologia do fígado de Clarias gariepinus mostrou ainda que o lóbulo intramural é formado por cordões de hepatócitos que circunda os vasos sinusóides dilatados. A ocorrência de hepatócitos circundando os vasos sinusóides já havia sido observada por Santos (2003), em sua dissertação de mestrado, que afirmou ainda que os vasos sinusóides irradiam da veia porta 
e que, entre os cordões de hepatócitos, ocasionalmente, podem ser observados pequenos ductos biliares, sendo que estes não são freqüentes no parênquima hepático. Santos (2003) referiu-se ainda aos hepatócitos como sendo células grandes, com núcleo grande e arredondado apresentando um nucléolo evidente, com citoplasma vacuolizado e ligeiramente basófilo, e aos ductos biliares como sendo formados por epitélio cúbico circundado por tecido conjuntivo, reiterando que estes ductos podem ser encontrados próximos aos melanomacrófagos. Em nosso trabalho, verificamos como característica marcante do lóbulo intramural, a presença de melanomacrófagos de grande tamanho, que ocorrem com menor freqüência no corpo principal do fígado de Clarias gariepinus, seguindo a descrição de Santos (2003). Assim, podemos afirmar, pelos estudos histológicos que realizamos nos lóbulos intramurais, que estas estruturas são formadas por tecido hepático devido à presença de hepatócitos, sinusóides e melanomacrófagos em disposição semelhante à descrição feita por Santos (2003), no corpo principal do fígado.

Em se tratando das características gerais do sistema circulatório em peixes, os resultados observados nos espécimes de Clarias gariepinus seguem os padrões dos peixes ósseos em geral, como citado por Orr (1986) ao afirmar que, dos ciclóstomos aos teleósteos, com exceção dos dipnóicos, o sistema circulatório dos peixes é essencialmente um sistema simples, no qual apenas o sangue não-oxigenado passa pelo coração. Em seguida, é bombeado para as brânquias, oxigenado, e distribuído para o corpo. O coração possui quatro câmaras, mas somente duas delas (o átrio e o ventrículo) correspondem às quatro câmaras (átrios pares e ventrículos pares) dos vertebrados superiores. A primeira câmara do coração de um peixe, ou câmara receptora, é chamada de seio venoso. Tem uma parede fina como a câmara seguinte, o átrio, para o qual o sangue passa. Do átrio, o sangue passa para o ventrículo, que tem paredes espessas, e é bombeado para fora, passando do cone arterioso para a aorta ventral. O sangue da aorta ventral vai para a região branquial para ser oxigenado, passando 
pelos vasos branquiais aferentes, depois disso, sai das brânquias através das alças coletoras eferentes e vai para a aorta dorsal. Estes vasos são derivados dos arcos aórticos, que ligam as aortas ventral e dorsal.

Em relação à posição ocupada pelo coração observou-se que, em Clarias gariepinus, esse órgão está alojado em uma cavidade pericárdica situada em posição medial, imediatamente cranial à cintura peitoral, logo após as brânquias. Essas considerações coincidem com os comentários de Bond (1996) ao referir-se à localização que normalmente é ocupada pelo coração dos peixes, ou seja, em uma cavidade pericárdica sob ou logo atrás das brânquias.

No que diz respeito ao estudo do sistema porta hepático, verificou-se que, no bagre africano Clarias gariepinus, ele está representado por duas veias portas principais, direita e esquerda, levemente assimétricas em diâmetro, que drenam o sangue das vísceras correspondentes através de tributários distintos. Ainda, devido à situação peculiar dos lobos acessórios, definem-se mais duas veias portas secundárias ligadas às principais e designadas igualmente por acessórias, uma esquerda e outra direita. Ambas as vv. portas principais se ramificam atingindo o hilo da face visceral, enquanto que as vv. acessórias, diferentemente, penetram por uma região restrita do lobo. Através de ramos interlobares, ambas as vv. portas principais se anastomosam no parênquima hepático. Exceto pela presença das duas veias portas acessórias, no mais, o sistema porta hepático em Clarias gariepinus assemelha-se àquele observado na carpa (Cyprinus carpio) por Harder (1975) ao comentar que o sistema porta hepático é bem desenvolvido nesses peixes assim como em outros vertebrados. Todo o sangue que é fornecido para os órgãos da cavidade corpórea pela artéria intestinal e suas artérias tributárias é recebido através das veias porta-hepática e precisa passar através do fígado. Não existe nenhum desvio ao redor desse órgão, tal como aquele que ocorre no sistema porta-renal. Do fígado, o sangue é conduzido pela veia hepática ao seio venoso. 
Um dos estudos mais respeitados no que tange ao sistema porta hepático em peixes é aquele desenvolvido por Allen (1905), que utilizou como modelo biológico a espécie Ophiodon elongatus, sendo bastante criterioso na descrição desse sistema, apesar da precariedade de recursos característica da época em que o trabalho foi publicado. Já, em relação ao sistema porta hepático de Clarias gariepinus, contou-se apenas com uma referência, ou seja, o trabalho desenvolvido por Nawar (1955) que se ateve às singularidades desse sistema em Clarias lazera, considerado uma sinonímia de Clarias gariepinus por Teugels (1986). Dessa forma, seria prudente estabelecermos um paralelo entre essas duas obras e os resultados obtidos em nosso estudo, destacando o número de veias porta; a origem de cada veia porta; a ligação entre o sistema porta hepático e o sistema porta renal; a nomenclatura da veia intestinal cranial, bem como o trajeto percorrido por essa veia; a nomenclatura da veia intestinal caudal, e a possível ligação entre as veias porta.

No tocante ao número de veias porta, Nawar (1955) identificou apenas uma em Clarias lazera, enquanto que, Allen (1905) em Ophiodon elongatus, observou duas veias porta. Nosso estudo revela que Clarias gariepinus possui, na verdade, duas veias porta, diferindo do estudo de Nawar (1955). Essa divergência se caracteriza pelo fato de o autor assumir que o sangue drena do lobo hepático direito para o esquerdo, tirando a importância relativa de uma circulação separada e bilateral que o estudo no bagre revelou.

Com respeito à origem das veias porta, Nawar (1955) considerou que ela se caracteriza pela continuação da veia retal e pela chegada da veia mesentérica; em nosso trabalho, verificamos que a veia porta esquerda se forma pela continuação da v. intestinal caudal e pela confluência das veias gástrica esquerda e da v. porta acessória esquerda; já, a veia porta direita se forma pela continuação da veia intestinal cranial e pela confluência da veia porta acessória direita. 
No que tange à ligação do sistema porta hepático com o sistema porta renal, Nawar (1955) conseguiu observá-la, mas não chegou a descrevê-la com clareza, caracterizando essa ligação através das veias denominadas pelo autor como "j", "k" e "l” e da veia comum do primeiro dos dois vasos intercostais direitos. Em nosso trabalho, a ligação entre os dois sistemas foi confirmada e descrita, definindo-se um ramo comunicante com a veia caudal e outro com a veia porta renal direita, denominado de veia segmental.

Quanto à nomenclatura da veia intestinal cranial, Nawar (1955) caracterizou-a como veia mesentérica que, por sua vez, seria formada por 15 veias intestinais. Por outro lado, através de nosso estudo, a veia intestinal cranial foi caracterizada como tal, porém, formada por 7 a 8 veias mesentéricas, o que seria mais apropriado pois esses vasos se localizam especificamente no mesentério.

Concernente ao trajeto descrito pela veia intestinal cranial, Nawar (1955) definiu-o em direção à veia retal, enquanto que nós consideramos que sua direção é no sentido da veia porta direita.

Em relação à nomenclatura da veia intestinal caudal, Nawar (1955) confundiu-a com a veia porta esquerda, enquanto que nós conseguimos definir adequadamente a origem dessa veia porta e seus tributários.

No que diz respeito à ligação entre as duas veias porta principais, Nawar (1955) caracterizou-a como veia anastomosadora localizada dentro do fígado, e nós confirmamos sua presença por intermédio de molde vascular de cloreto de polivinil obtido através de corrosão.

E, finalmente, para balizar futuros trabalhos de hepatectomia parcial em Clarias gariepinus recomendamos que, para atingir hepatectomias de $30 \%$, como o proposto por Santos (2003), a remoção do tecido hepático fosse feita tanto no lobo esquerdo como no direito, uma vez que as veias portas atingem seus respectivos lobos de maneira simétrica, não 
interferindo, dessa forma, no resultado da retirada de massa hepática. Porém, seria fundamental preservar a comunicação do fígado com a alça proximal do intestino, evitandose, assim, cortar o colédoco; no entanto, este cuidado foi imaginário no trabalho de Santos (2003), pois não se sabia onde o colédoco estava situado. Nossos estudos revelaram que ele se abre, provavelmente, bem após o piloro, o que leva a uma certa segurança em se avançar o corte para o plano mediano do fígado. Um estudo anatômico mais aprofundado poderia mostrar esta relação, desde que fosse injetado todo o sistema bilífero do peixe, tentativa esta não executada por nenhum pesquisador até o presente momento. Ressalta-se ainda que as hepatectomias em Clarias gariepinus são geralmente muito seguras, pois a v. intestinal cranial funciona como um caminho de ligação (anastomose) entre os dois lobos; para confirmar este fato, poderia ser feito um estudo piloto antes de se realizar as hepatectomias, ligando os vasos seletivamente e observando in locu os efeitos da mudança de circulação.

Considera-se ainda que, pelo fato de as v. portas serem levemente assimétricas, sendo a esquerda um pouco maior em calibre e recebendo mais vasos que a direita, o efeito da ligadura ou de uma hepatectomia parcial assumiria proporções diferentes conforme o lado escolhido, pois os lobos hepáticos recebem sangue de maneira assimétrica. Além disso, vale a pena ressaltar que, em razão de o ramo anastomótico intra-hepático não ter sido muito explorado neste trabalho, seria difícil delinearmos a circulação intra-hepática antes e após as hepatectomias parciais, abrindo assim um precedente para avançarmos nestes estudos, preparando novos moldes de corrosão, seguidos de experimentos que testem diferentes níveis de hepatectomia parcial. 


\section{CONCLUSÕES}

Diante das condições sob as quais o trabalho foi desenvolvido e levando-se em consideração a metodologia proposta e a análise dos resultados, conclui-se que:

$\checkmark$ Os quatro métodos (injeção de látex seguida de dissecação; injeção de cloreto de polivinil seguida de corrosão; aplicação de contraste radiopaco para posterior radiografia, e análise histológica do fígado através dos procedimentos propostos por Bouin e Mc Dowell) utilizados para observação macroscópica ou microscópica do sistema porta hepático de Clarias gariepinus, foram adequados ao estudo do aparelho circulatório nesta espécie, sendo recomendados para outros experimentos em peixes que tratem do mesmo assunto, visto que são complementares;

$\checkmark$ Dentre as três metodologias utilizadas para análise macroscópica, a injeção de cloreto de polivinil, seguida de corrosão das peças em solução de ácido acético e ácido clorídrico, e subseqüente obtenção de molde vascular, foi a técnica que melhor demonstrou os resultados a que se propôs o trabalho, ou seja, marcar e identificar os vasos que compõem o sistema porta hepático de Clarias gariepinus;

$\checkmark$ O fígado de Clarias gariepinus apresenta uma lobação peculiar possuindo, além dos dois lobos principais (esquerdo e direito) e tradicionais em peixes, mais dois lobos acessórios (também chamados esquerdo e direito) posicionados em um recesso peritoneal lateral à cavidade abdominal, um local onde, até então, não haviam sido observados em nenhuma outra espécie;

$\checkmark$ Os lobos acessórios estão diretamente ligados ao fígado e recebem a circulação deste, portanto sofrem os mesmos estímulos através do sangue que serve as porções principais do fígado; 
$\checkmark$ A circulação porta em Clarias gariepinus apresenta uma particularidade em relação àquela encontrada em outras espécies, uma vez que, no bagre africano, além das duas veias porta tradicionais, estão presentes mais duas veias porta acessórias, que ligam os lobos acessórios aos lobos principais;

O sistema porta hepático de Clarias gariepinus apresenta uma anastomose entre as duas veias porta principais, a qual ocorre dentro do parênquima hepático, sendo que, em virtude dessa ligação, uma das veias porta poderia compensar a irrigação exercida pela outra, caso esta tenha sido removida por ocasião de uma hepatectomia parcial. 


\section{REFERÊNCIAS}

ALLEN, W. F. The blood-vascular system of the Loricati, the mail-cheeked fishes. Proceedings of the Washington Academy of Sciences, Washington, v. 7, p. 27-157, 1905. plates 1-6.

AMLACHER, E. Beitrag zur anatomie der karpfenleber (Cyprinus carpio L.). Zeitschrift für Fischerei, Berlin, v. 3, p. 311-336, 1954.

BEHMER, O. A.; TOLOSA, E. M. C.; NETO, A. G. F. Manual de técnicas para histologia normal e patológica. São Paulo: Editora da Universidade de São Paulo, 1976. 241 p.

BOND, C. E. Biology of fishes. 2. ed. Philadelphia: Saunders College Publishing, 1996. 750 p.

BROWN, L. A. Recirculation anaesthesia for laboratory fish. Laboratory animals, London, v. 21, p. 210-215, 1987.

. Anaesthesia and restraint. In: Fish medicine. Philadelphia: MK

Stoskopf, W. B. Saunders, 1993. p. 79-90.

BUNTON, T. E. The immunohistochemistry of cytokeratin in fish tissues. Veterinary Pathology, v. 30, p. 418-425, 1993.

BURGESS, W. E. An atlas of freshwater and marine catfishes: a preliminary survey of the siluriformes. Neptune City: T. F. H. Publications, 1989. 480 p.

CLARIAS. Panorama da aqüicultura, v. 4, n. 22, p. 16-18, mar./abr. 1994.

COHEN, D. M. How many recent fishes are there? Proceedings of the California Academy Sciences, v. 4, n. 38, p. 341-346, 1970.

FINK, S. V.; FINK, W. L. Interrelationships of the ostariophysan fishes (Teleostei). Zoological Journal of the Linnean Society, v. 72, n. 1-4, p. 297-353, 1981.

GREEN, C. J. Animal anaesthesia. London: The British Council, 1979. 701 p. (Laboratory Animals Handbooks, 8).

HAMPTON, J. A.; LANTZ, R. C.; GOLDBLATT, P. J.; LAUREN, D. J.; HINTON D. E. Functional units in rainbow trout (Salmo gairdneri Richardson) liver II. The biliary system. The Anatomical Record, v. 221, p. 619-635, 1988.

HAMPTON, J. A.; LANTZ, R. C.; HINTON D. E. Functional units in rainbow trout (Salmo gairdneri Richardson) liver III. Morphometric analysis of parenchima, stroma, and component cell types. The American Journal of Anatomy, v. 185, p. 58-73, 1989.

HARDER, W. Anatomy of fishes: part I - text. Stuttgart: Schweizerbart'sche Verlagsbuchhandlung, 1975. $612 \mathrm{p}$. 
HILDEBRAND, M. Análise da estrutura dos vertebrados. São Paulo: Atheneu, 1995. 700 p.

INSTITUTO BRASILEIRO DO MEIO AMBIENTE E DOS RECURSOS NATURAIS RENOVÁVEIS. Portaria $n^{\circ}$ 142/94 de 22 de dezembro de 1994. Brasília: IBAMA, 1994. Disponível em: <www.nepam. unicamp.br/legislação/portarial142_dez94.htm>. Acesso em 7/set./2004. Publicada no Diário Oficial da União de 23/12/94, seção I, artigo 1º, p. 20437.

INTELIZANO, W. Origem e distribuição das artérias coronárias em carpa-capim Ctenopharyngodon idella Valenciennes, 1884 (Cyprinidae, Ostariophysii). 1999. 120 f. Tese (Doutorado em Anatomia dos Animais Domésticos) - Faculdade de Medicina Veterinária e Zootecnia, Universidade de São Paulo, São Paulo, 1999.

NAWAR, G. On the anatomy of Clarias lazera - the vascular system. Journal of Morfology, v. 97, n. 2, Sudan, p. 179-214, set. 1955.

NELSON, J. S. Fishes of the world. 3. ed. New York: John Wiley \& Sons, 1994. 600 p.

OKIHIRO, M. S.; HINTON, D. E. Partial hepatectomy and bile duct ligation in rainbow trout (Oncorhynchus mykiss): Histologic, immunohistochemical and enzyme histochemical characterization of hepatic regeneration and biliary hyperplasia. Toxicologic Pathology, v. 28, p. 342-356, 2000.

ORR, R. T. Biologia dos vertebrados. 5. ed. San Francisco: California Academy of Sciences, 1986. p. 26-35.

POUGH, F. H. Vida dos vertebrados. 2. ed. São Paulo: Atheneu, 1999. 798 p.

ROMER, A. S.; PARSONS, T. S. Anatomia comparada dos vertebrados. São Paulo: Atheneu, 1985. $559 \mathrm{p}$.

ROUX, W. Über die entwicklung der leber. Archiv für Entwicklungsmechanik, v. 51, p. 310-314, 1922.

SANTOS, N. P. Regeneração hepática em bagre africano (Clarias gariepinus) após hepatectomia parcial. 2003. 61 f. Dissertação (Mestrado em Zootecnia) - Faculdade de Zootecnia e Engenharia de Alimentos, Universidade de São Paulo, Pirassununga, São Paulo, 2003.

STORER, T. I.; USINGER, R. L.; STEBBINS, R. C.; NYBAKKEN, J. W. Zoologia geral. 6. ed. rev. e aum. São Paulo: Companhia Editora Nacional, 1998. p. 76-103.

TEUGELS, G. G. A systematic revision of the african species of the genus Clarias (Pisces; Clariidae). Zoologische Wetenschappen: Sciences Zoologiques, v. 247, p. 2-192, 1986.

UZUNIAN, A.; CALDINI Jr, N. Biologia 2. São Paulo: Anglo, 2002. p. 292. (Coleção Anglo: livro-texto).

VIEIRA, F. Peixamentos - uma alternativa eficiente? Ciência Hoje, v. 30, n. 175, p. 28-33, set. 2001. 


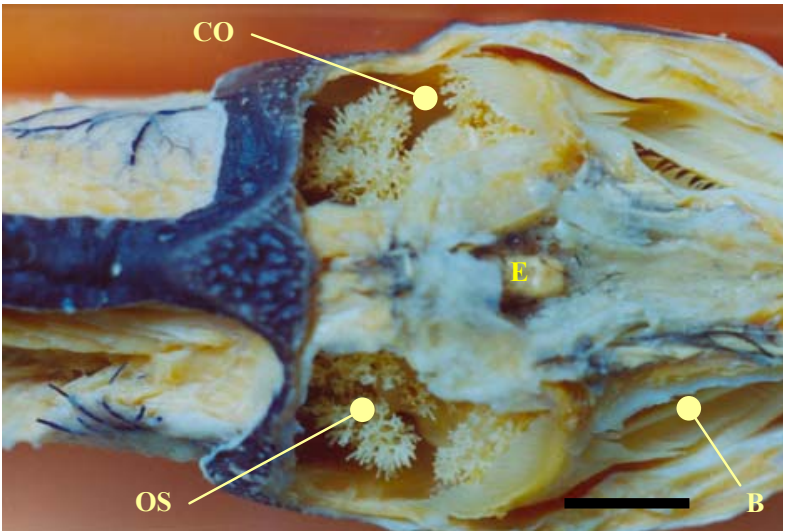

Anexo A- Vista dorso-ventral com o peixe dissecado a partir da retirada do tecido ósseo e muscular da porção dorsal da cabeça, expondo as cavidades orobranquiais $(\mathrm{CO})$, onde estão alojados os órgãos suprabranquiais (OS). E - encéfalo; B - Brânquias. Barra $=4 \mathrm{~mm}$

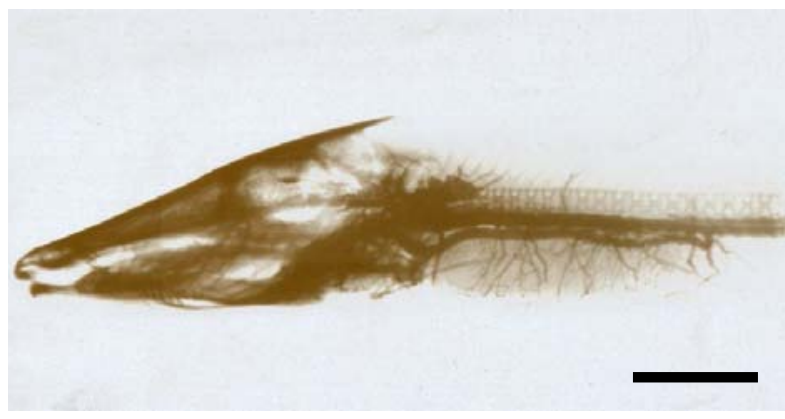

Anexo C- Vista látero-lateral do negativo da radiografia de Clarias gariepinus, obtida após aplicação de substância radiopaca. Verificar o formato achatado da cabeça de Clarias gariepinus. Barra $=3,2 \mathrm{~mm}$

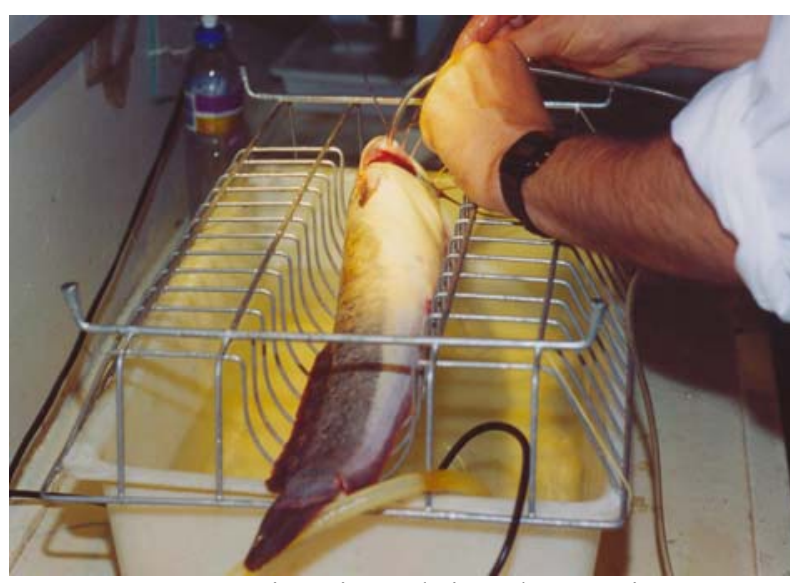

Anexo E- Mesa cirúrgica abrigando o peixe 1 em decúbito lateral (com $48 \mathrm{~cm}$ de comprimento), sendo submetido à anestesia, para preparação requerida pelos procedimentos cirúrgicos

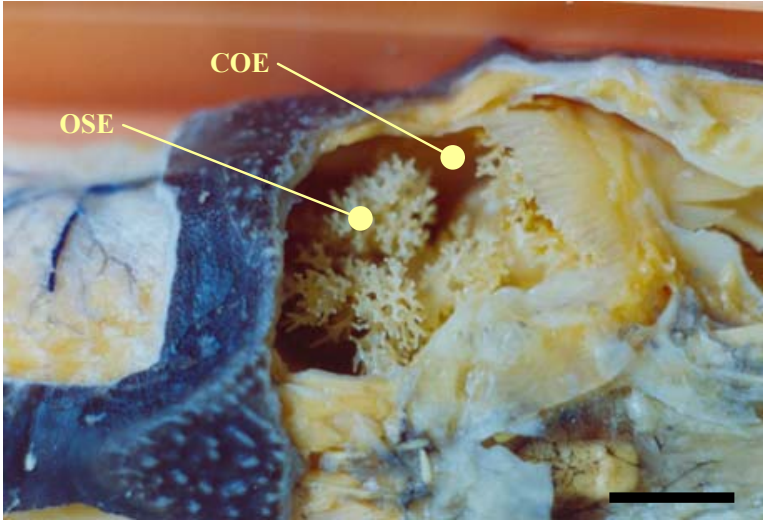

Anexo B- Vista dorso-ventral da cabeça de Clarias gariepinus, detalhando o órgão suprabranquial esquerdo (OSE). COE Cavidade orobranquial esquerda. Barra $=$ $6 \mathrm{~mm}$

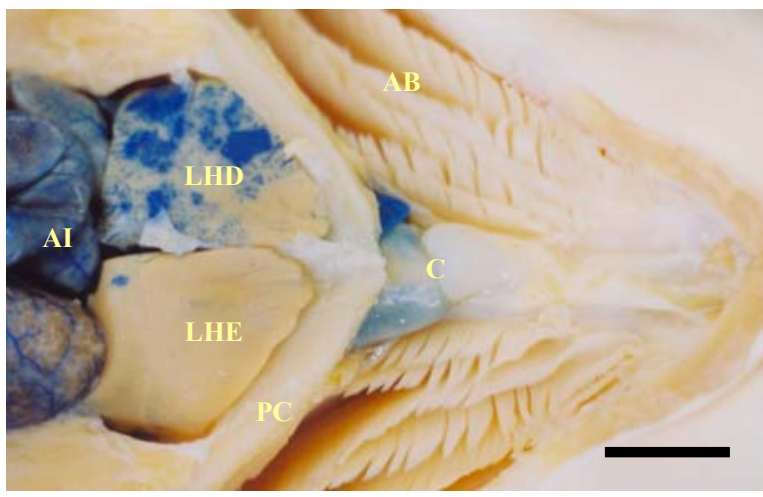

Anexo D- Vista ventro-dorsal da cabeça de Clarias gariepinus detalhando a posição ocupada pelo coração (C). AB - Arcos branquiais; PC - Processo Coracóide; LHE - Lobo Hepático Esquerdo; LHD - Lobo Hepático Direito; AI - Alças Intestinais. Barra $=5,3 \mathrm{~mm}$

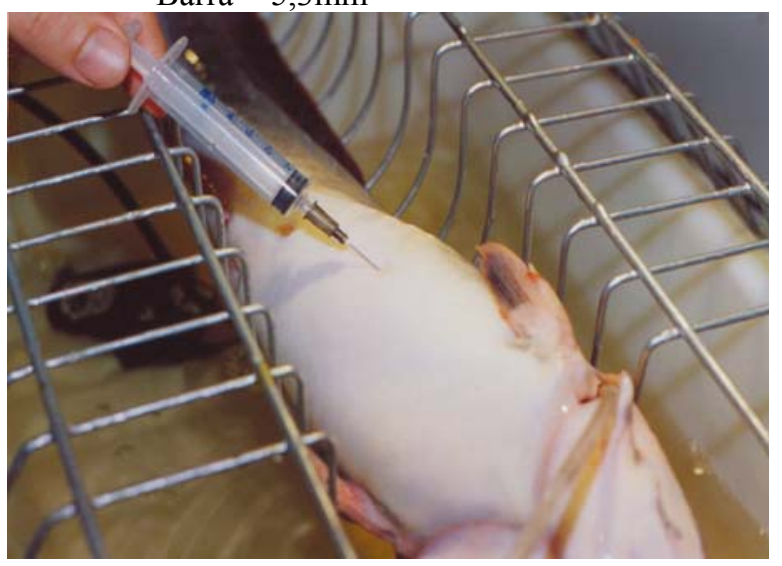

Anexo F- Detalhe da aplicação intra-abdominal de heparina sódica (anticoagulante) no peixe 1 em decúbito dorsal, após sedação leve em solução anestésica com $25 \mathrm{mg} / \mathrm{L}$ de benzocaína 


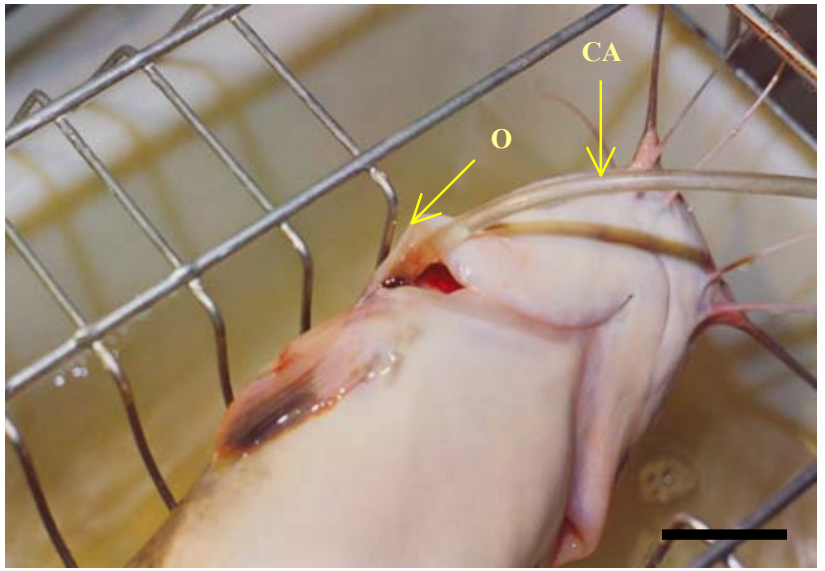

Anexo G- Detalhe da sedação profunda com benzocaína $(50 \mathrm{mg} / \mathrm{L})$ aplicada em fluxo contínuo, irrigando as brânquias do peixe, até que ele atinja o estado de narcose profunda. $\mathrm{O}-$ Opérculo; CA - Canícula com anestésico. Barra $=2,5 \mathrm{~mm}$

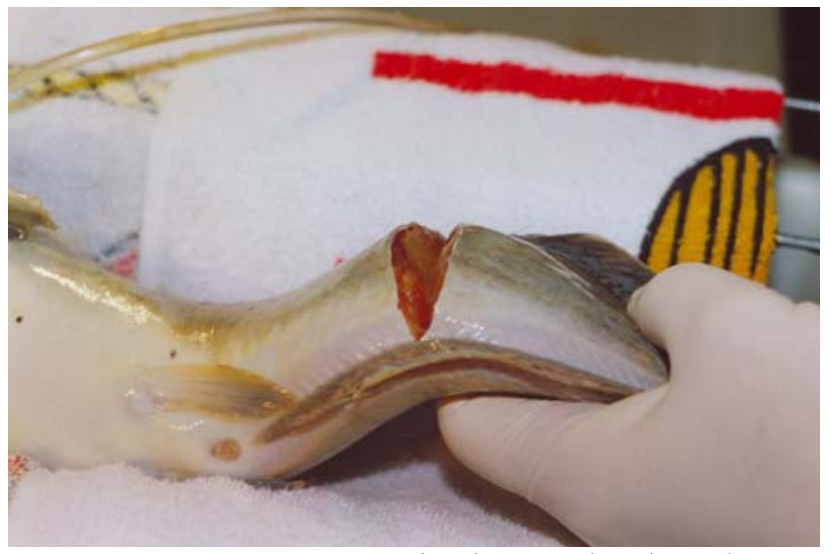

Anexo I- Secção transversal da cauda de Clarias gariepinus, feita para retirada do sangue e exposição da veia e da artéria caudal utilizadas para perfusão sangüínea e para injeção das substâncias recomendadas ao estudo do sistema circulatório

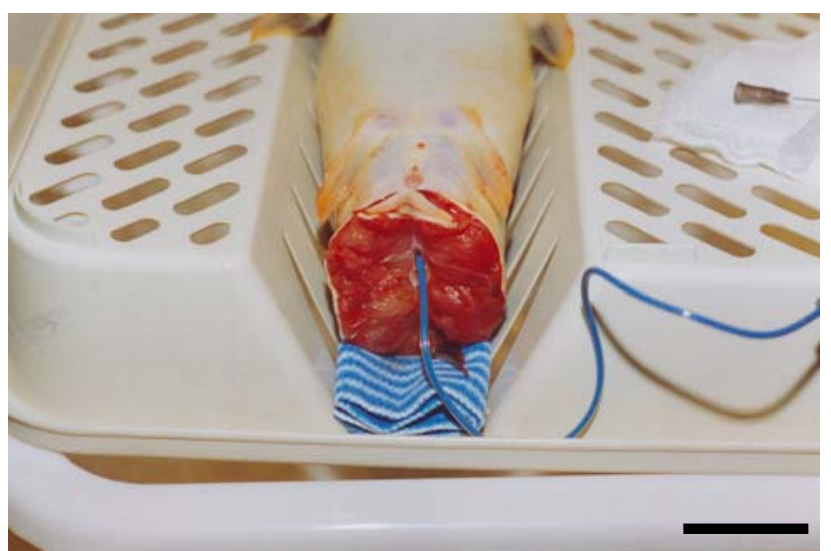

Anexo L- Detalhe da injeção de látex corado em azul aplicado através da veia caudal do peixe. Barra $=4 \mathrm{~mm}$

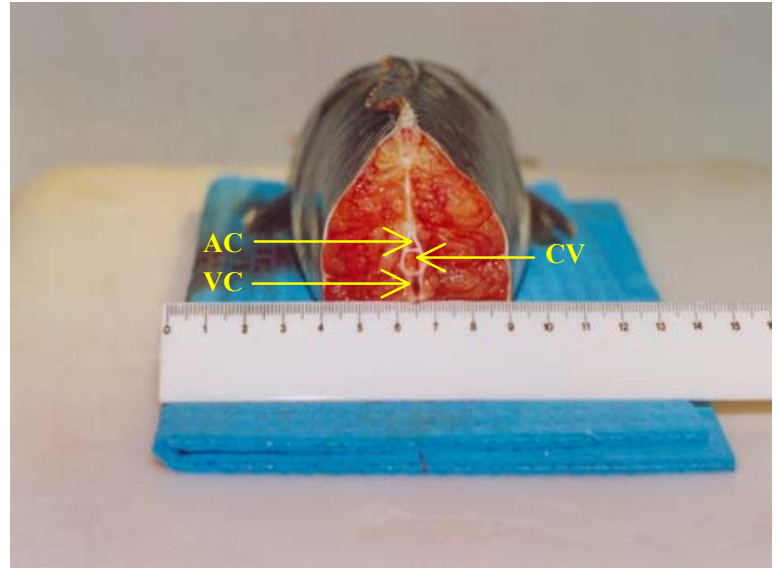

Anexo H- Detalhe da posição ocupada pela veia caudal (VC) e pela artéria caudal (AC) em Clarias gariepinus, expondo os dois principais sítios de canulação para injeção. CV - Coluna Vertebral

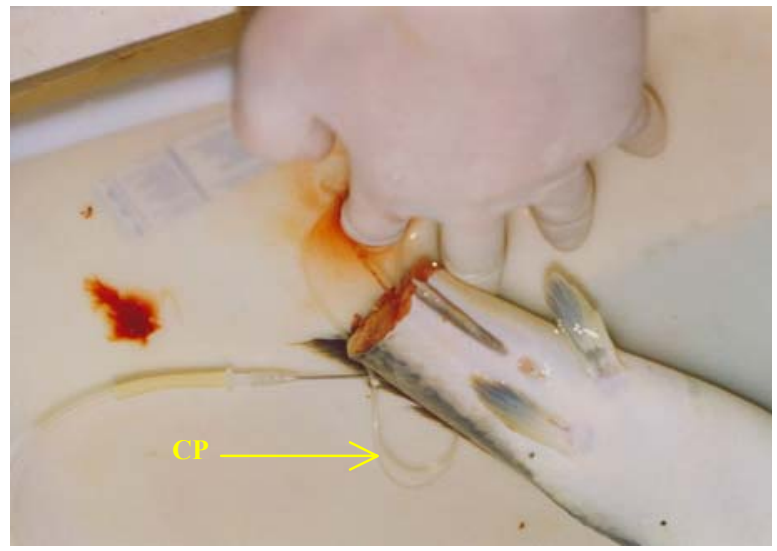

Anexo J- Retirada do sangue e higienização dos vasos sangüíneos através da perfusão de soro fisiológico heparinizado. CP - Cânula de Perfusão

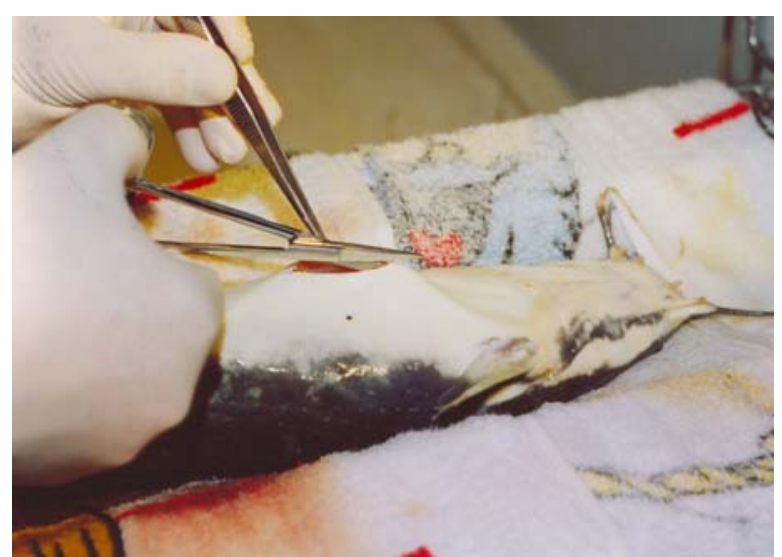

Anexo M- Incisão addominal em sua linha média para exposição das vísceras e o acompanhamento da injeção 


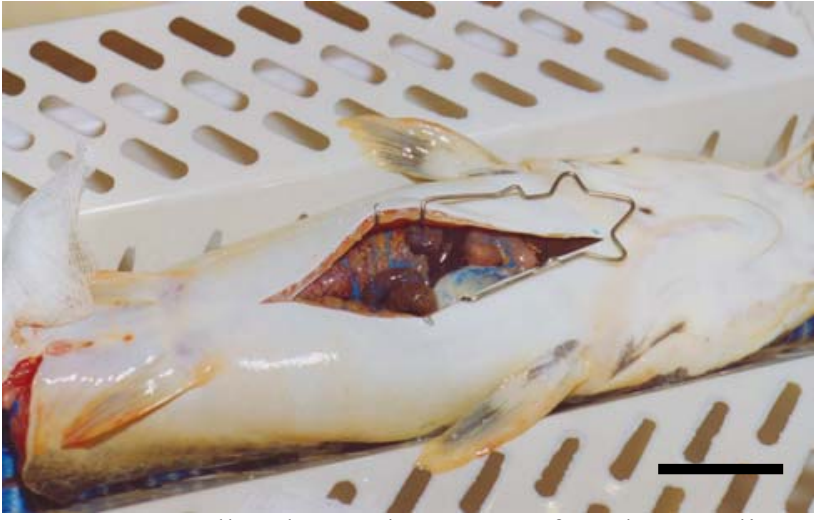

Anexo N- Detalhe do uso de grampo afastador metálico utilizado para permitir a visualização da injeção. Barra $=2,85 \mathrm{~mm}$

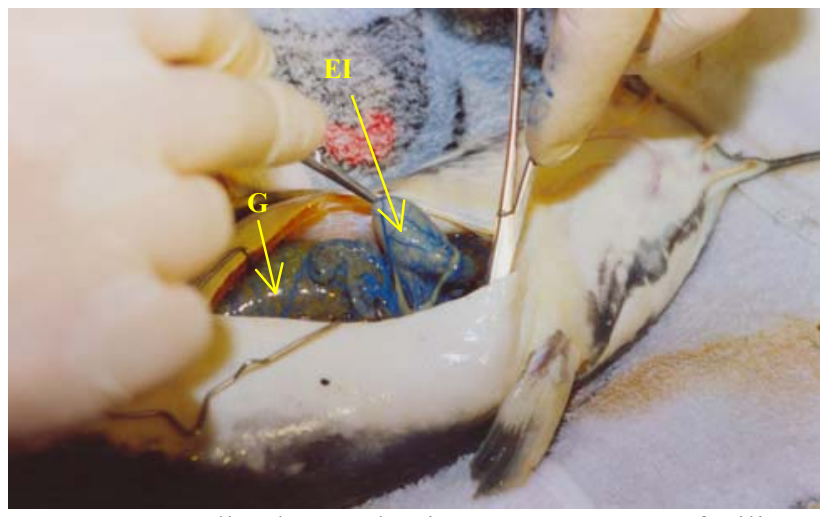

Anexo P- Detalhe do uso de pinça e tesoura para facilitar a visualização da injeção. EI - estômago injetado; $\mathrm{G}$ - gônada

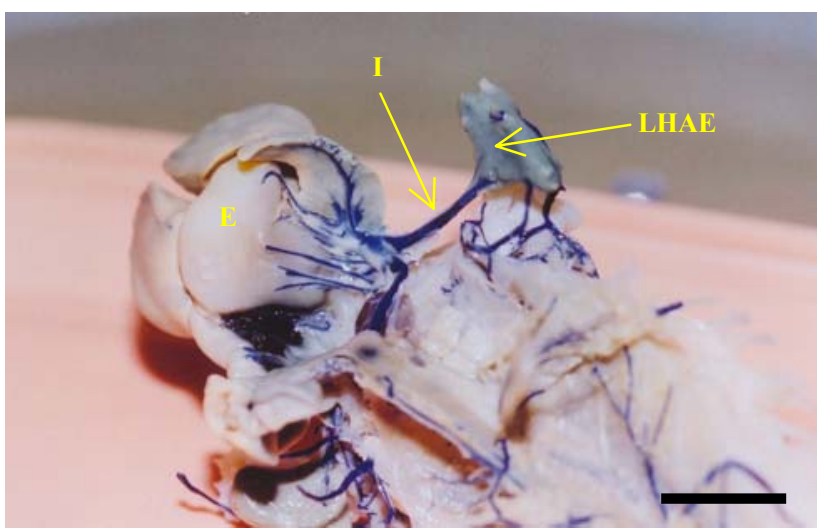

Anexo R-Molde vascular parcial obtido a partir da técnica de injeção do sistema venoso com cloreto de polivinil (vinilite), seguida de corrosão parcial da peça em solução corrosiva. I - istmo; LHAE - lobo hepático acessório esquerdo; $\mathrm{E}$ - estômago. Barra =6,3 $\mathrm{mm}$

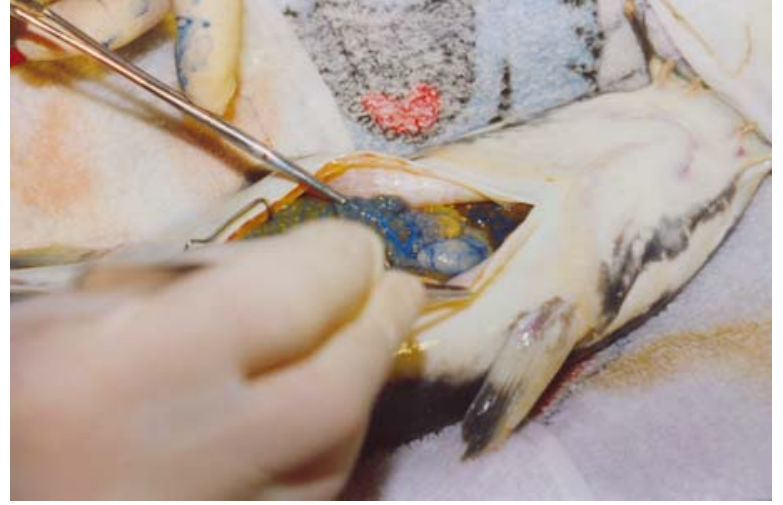

Anexo O- Detalhe do uso de pinças para facilitar a visualização da injeção

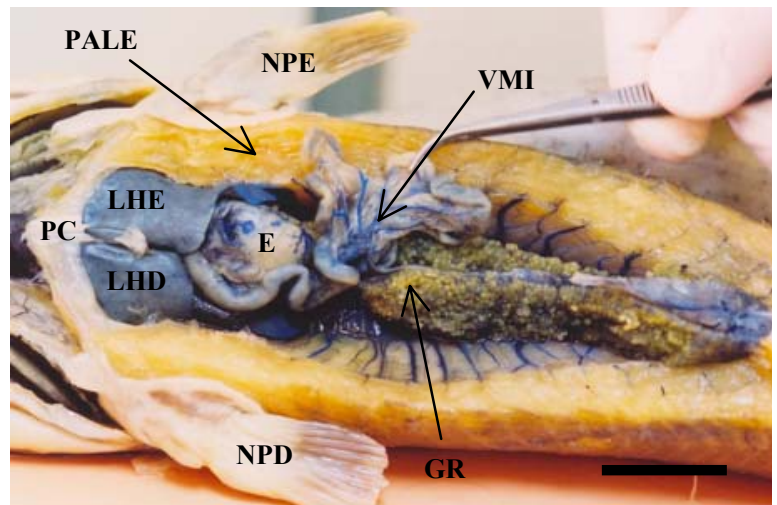

Anexo Q- Dissecção em estágio inicial expondo as vísceras injetadas. PALE - parede abdominal lateral esquerda; NPE nadadeira peitoral esquerda; VMI - veias mesentéricas injetadas; GR - gônadas removidas; NPD - nadadeira peitoral direita; E - estômago; LHE - lobo hepático esquerdo; LHD - lobo hepático direito; $\mathrm{PC}-$ processo coracóide. Barra $=$ $3,7 \mathrm{~mm}$

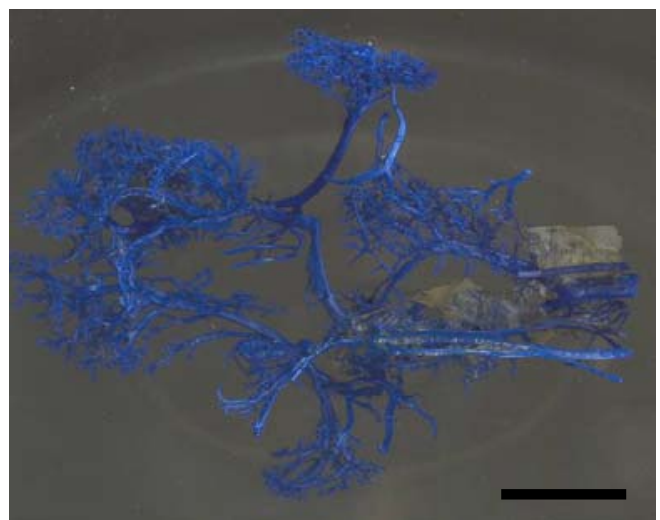

Anexo S- Molde vascular definitivo obtido a partir da técnica de injeção do sistema venoso com cloreto de polivinil (vinilite), seguida de corrosão total da peça em solução corrosiva. Barra $=6,7 \mathrm{~mm}$ 


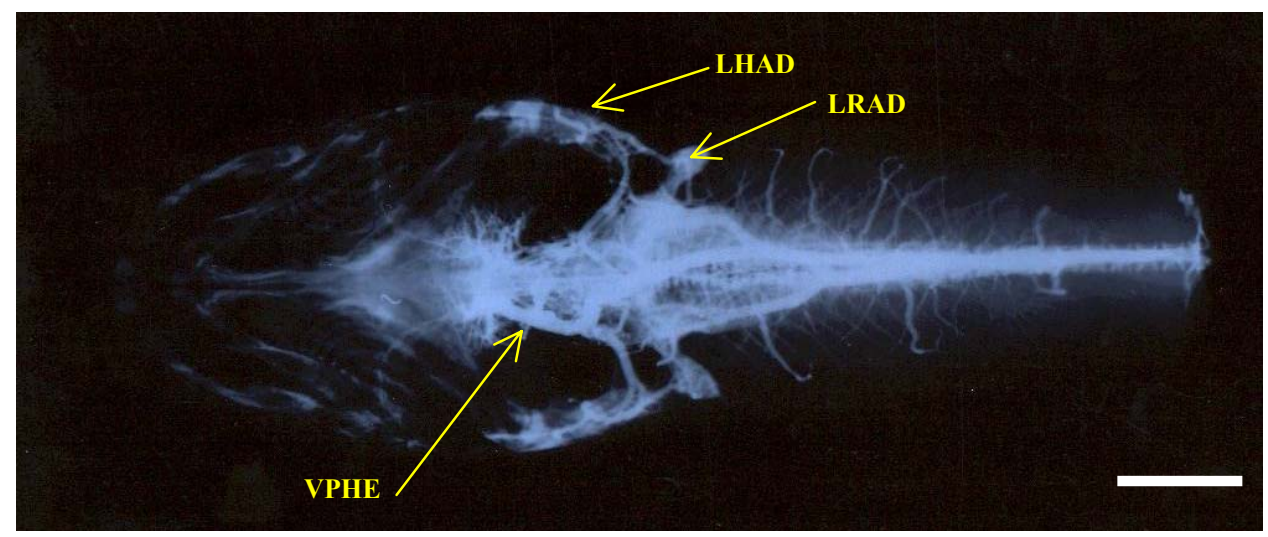

Anexo T- Radiografia em vista dorso-ventral, obtida após injeção de substância radiopaca (sulfato de bário) efetuada na veia caudal do peixe. LHD - lobo hepático acessório direito; LRAD - lobo renal acessório direito; VPHE - veia porta hepática esquerda. Barra $=4,4 \mathrm{~mm}$

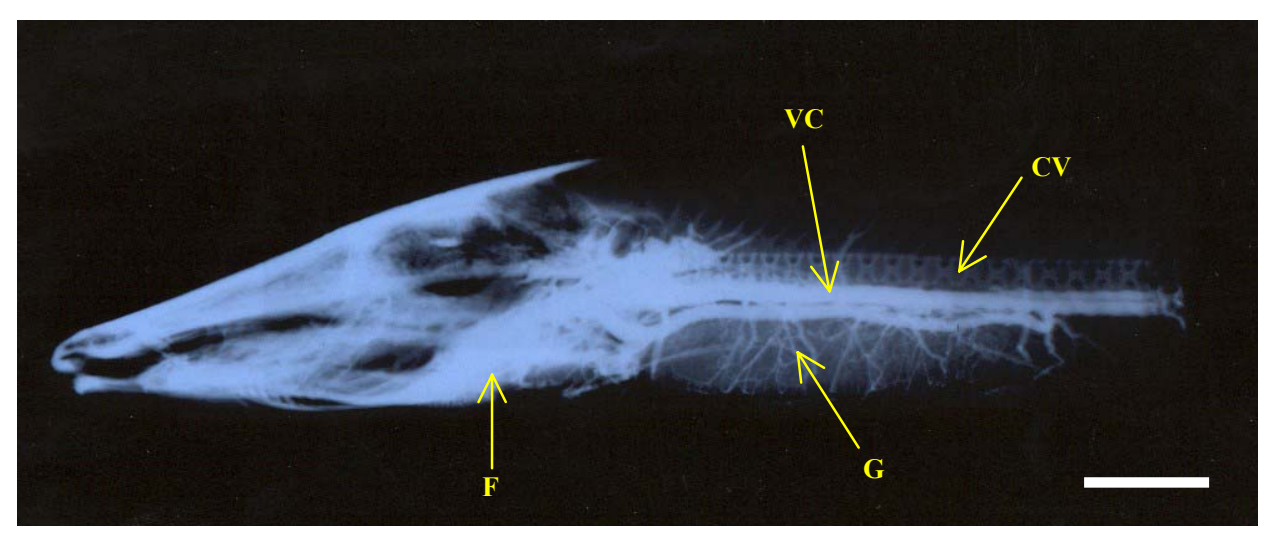

Anexo U- Radiografia em vista látero-lateral, obtida após injeção de substância radiopaca (sulfato de bário) efetuada na veia caudal do peixe. F- fígado; $\mathrm{VC}-$ veia caudal; CV - coluna vertebral; G - gônada. Barra = 4,8 mm

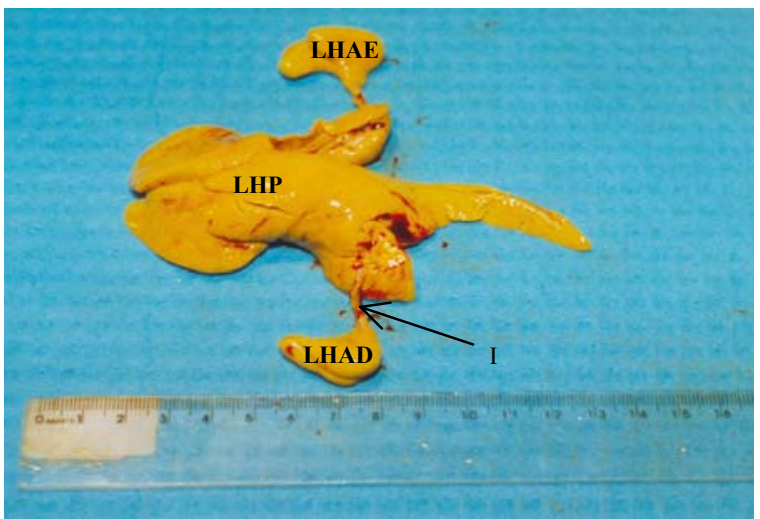

Anexo V-Vista ventral do fígado de Clarias gariepinus a fresco, expondo a lobação irregular do órgão. Detalhes do lobo hepático principal (LHP), dos lobos acessórios e do istmo ( I ). LHAD - lobo hepático acessório direito; LHAE - lobo hepático acessório esquerdo

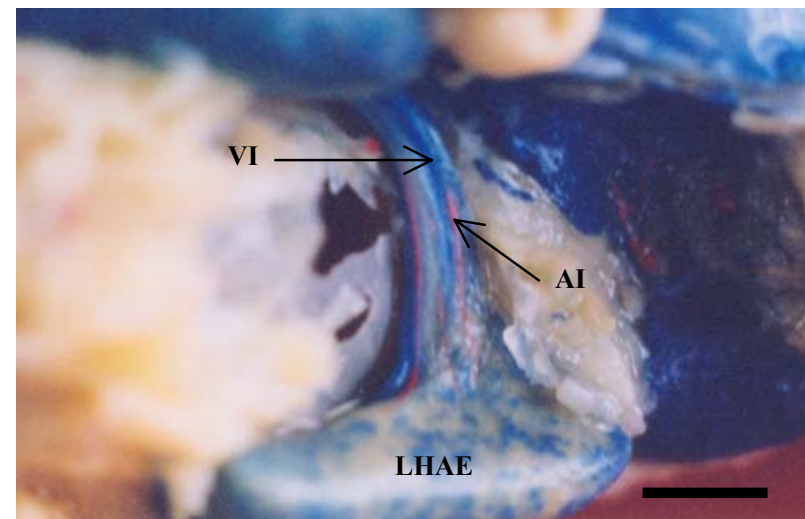

Anexo X- Detalhe do lobo hepático acessório esquerdo (LHAE) caracterizando as artérias e veias que irrigam e drenam o órgão, injetadas com látex corado em vermelho $\mathrm{e}$ azul, respectivamente. AI - artéria injetada; VI veia injetada. Barra $=16 \mathrm{~mm}$ 


\begin{tabular}{|c|c|c|c|c|c|c|}
\hline$N^{0}$ do peixe & $\begin{array}{l}\text { Material } \\
\text { injetado }\end{array}$ & $\begin{array}{c}\text { Quantidade } \\
\text { injetada } \\
(\mathrm{ml})\end{array}$ & $\begin{array}{l}\text { Via de } \\
\text { injeção }\end{array}$ & $\begin{array}{c}\text { Técnica } \\
\text { utilizada } \\
\text { após a } \\
\text { injeção }\end{array}$ & $\begin{array}{l}\text { Massa } \\
\text { corpórea } \\
\text { do peixe } \\
\text { (g) }\end{array}$ & $\begin{array}{c}\text { Comprimento } \\
\text { do peixe } \\
\text { (cm) }\end{array}$ \\
\hline 1 & Látex azul & 7 & Veia caudal & Dissecação & 840 & 48 \\
\hline 2 & $\begin{array}{c}\text { Látex } \\
\text { vermelho }\end{array}$ & 5,5 & Artéria caudal & Dissecação & 803 & 45 \\
\hline 3 & $\begin{array}{l}\text { a) Látex azul } \\
\text { b) Nanquim } \\
\text { Preto }\end{array}$ & $\begin{array}{c}10,5 \\
10\end{array}$ & $\begin{array}{c}\text { Veia caudal } \\
\text { Artéria caudal }\end{array}$ & Dissecação & 1068 & 51 \\
\hline 4 & Látex azul & 9,5 & Veia caudal & Dissecação & 920 & 49,3 \\
\hline 5 & $\begin{array}{c}\text { Cloreto de } \\
\text { polivinil }\end{array}$ & 10 & Veia caudal & Corrosão & 954 & 52,5 \\
\hline 6 & $\begin{array}{c}\text { Cloreto de } \\
\text { polivinil } \\
\end{array}$ & 10 & Veia caudal & Corrosão & 813 & 51,5 \\
\hline 7 & $\begin{array}{l}\text { a) Látex azul } \\
\text { b) Látex } \\
\text { vermelho }\end{array}$ & $\begin{array}{c}13 \\
4\end{array}$ & $\begin{array}{c}\text { Veia caudal } \\
\text { Artéria caudal }\end{array}$ & Dissecação & 876,5 & 53,5 \\
\hline 8 & $\begin{array}{c}\text { Celobar } \\
\text { (Sulfato de } \\
\text { Bário) }\end{array}$ & 6 & Veia caudal & Radiografia & 612,5 & 46 \\
\hline 9 & Látex & 12,5 & Veia caudal & Dissecação & 861,5 & 50,5 \\
\hline 10 & $\begin{array}{l}\text { Fixador de } \\
\text { Bouin }\end{array}$ & 50 & $\begin{array}{l}\text { Veia caudal } \\
\text { (perfusão) }\end{array}$ & $\begin{array}{c}\text { Confecção } \\
\text { de lâminas } \\
\text { para } \\
\text { histologia }\end{array}$ & 643,5 & 46 \\
\hline 11 & $\begin{array}{c}\text { Cloreto de } \\
\text { polivinil } \\
\end{array}$ & 8 & Veia caudal & Corrosão & 575 & 46,5 \\
\hline 12 & $\begin{array}{l}\text { a) Látex azul } \\
\text { b) Látex } \\
\text { vermelho }\end{array}$ & $\begin{array}{c}10 \\
5\end{array}$ & $\begin{array}{c}\text { Veia caudal } \\
\text { Artéria caudal }\end{array}$ & Dissecação & 761 & 49 \\
\hline 13 & $\begin{array}{l}\text { Fixador de Mc } \\
\text { Dowell }\end{array}$ & 50 & $\begin{array}{l}\text { Veia caudal } \\
\text { (perfusão) }\end{array}$ & $\begin{array}{c}\text { Confecção } \\
\text { de lâminas } \\
\text { para } \\
\text { histologia }\end{array}$ & 788,5 & 46 \\
\hline 14 & $\begin{array}{l}\text { a) Látex azul } \\
\text { b) Látex } \\
\text { amarelo }\end{array}$ & $\begin{array}{c}10 \\
5\end{array}$ & $\begin{array}{c}\text { Veia caudal } \\
\text { Veia hepática }\end{array}$ & Dissecação & 901 & 49,7 \\
\hline 15 & $\begin{array}{l}\text { a) Látex azul } \\
\text { b) Látex } \\
\text { amarelo }\end{array}$ & $\begin{array}{c}10 \\
5\end{array}$ & $\begin{array}{c}\text { Veia caudal } \\
\text { Veia hepática }\end{array}$ & Dissecação & 789 & 47 \\
\hline 16 & $\begin{array}{l}\text { a) Látex azul } \\
\text { b) Látex } \\
\text { amarelo }\end{array}$ & $\begin{array}{c}10 \\
5\end{array}$ & $\begin{array}{c}\text { Veia caudal } \\
\text { Veia hepática }\end{array}$ & Dissecação & 814 & 48 \\
\hline
\end{tabular}

Anexo Z-Quadro elucidativo relacionando o $\mathrm{n}^{\mathrm{o}}$ de animais utilizados nos experimentos com os materiais utilizados para injeção, bem como a quantidade utilizada de cada produto e a técnica à qual cada peixe foi submetido 


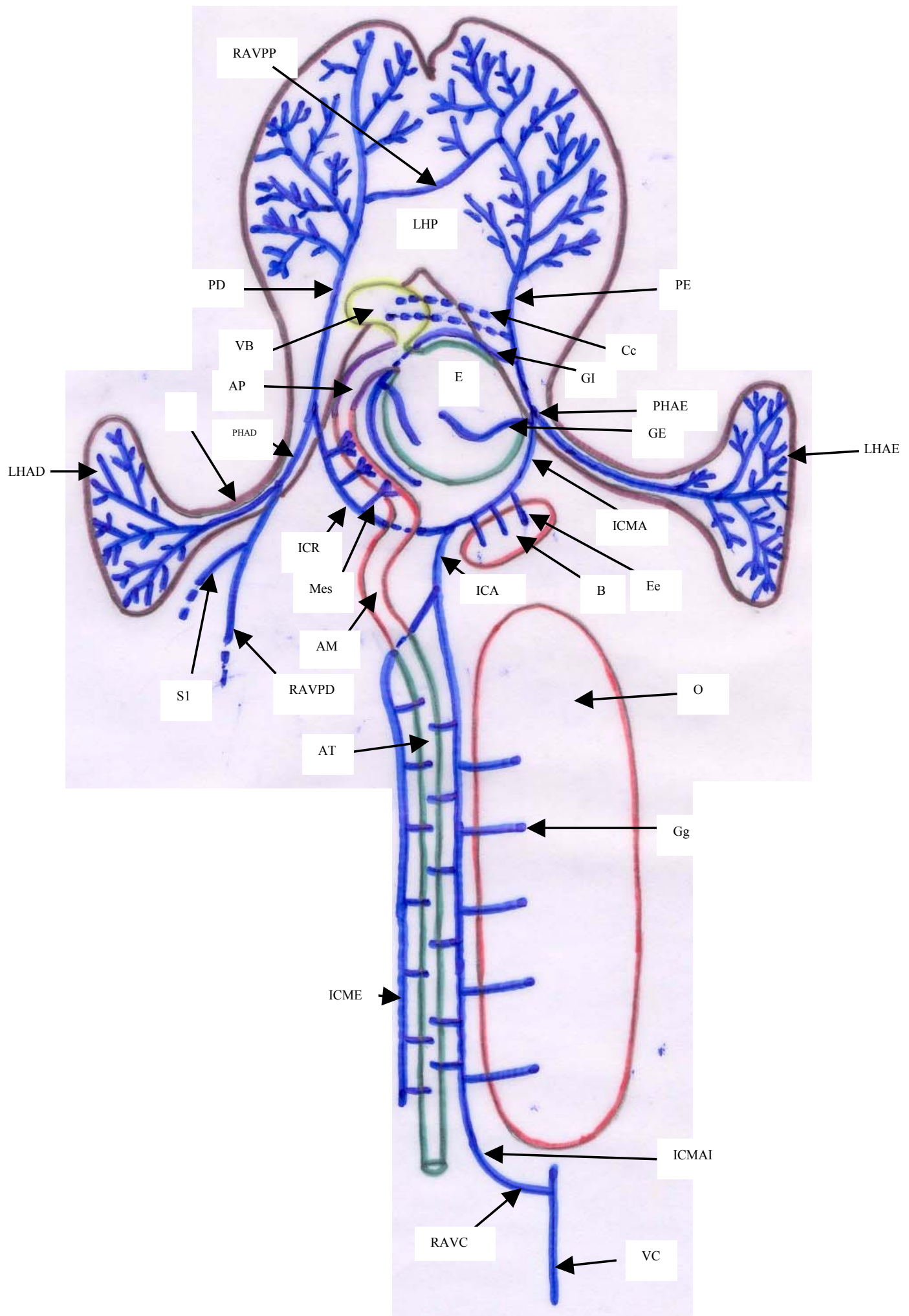

Anexo AA- Desenho esquemático da circulação porta hepática mostrando os vasos mais importantes e os órgãos que são drenados por estes vasos. RAVP- ramo anastomótico entre as veias porta principais; LHP- lobos hepáticos pricipais; Veias: PE- porta esquerda; Cc- císticas; PHAE- porta hepática acessória esquerda; GE- gástrica esquerda; GI- Gastrointestinal; ICMA- intestinal caudal maior; ICA- intestinal caudal; EeEsplênicas; Gg- gonadais; ICMAI- intestinal caudal maior; VC- veia caudal; RAVC- ramo anastomótico c/ a veia caudal; ICME- intestinal caudal menor; Mes- mesentéricas; ICR-intestinal cranial; RAVPDramo anastomótico p/ veia porta renal; S1- segmentais; PHAD- porta hepática acessória direita; PD- porta direita. Órgãos e adjacentes: E- estômago; LHAE- lobo hepático acessório esquerdo; B- baço; O- ovário; AT-alça intestinal terminal; AM- alça intestinal média; AP-alça intestinal proximal; LHAD- lobo hepático acessório direito; I- istmo; VB- vesícula biliar 